\title{
Are We Meeting the Challenges of Landscape-Scale Riverine Research? A Review
}

\author{
E. Ashley Steel ${ }^{1,2}$, Robert M. Hughes ${ }^{3,4}$, Aimee H. Fullerton ${ }^{1}$, Stefan Schmutz ${ }^{5}$, \\ John A. Young ${ }^{6}$, Michio Fukushima ${ }^{7}$, Susanne Muhar ${ }^{5}$, Michaela Poppe ${ }^{5}$, \\ Blake E. Feist ${ }^{1}$ and Clemens Trautwein ${ }^{5}$
}

Accepted on 10 May 2010

Published on 18 June 2010

1 Landscape Ecology and Recovery Science, NW Fisheries Science Center, NOAA Fisheries, 2725 Montlake Blvd. East, Seattle, WA, 98112, USA

2 Current affiliation: PNW Research Station, USDA Forest Service, 3625 93rd Avenue SW, Olympia, WA 98512, USA; e-mail: asteel@fs.fed.us

3 Dept. of Fisheries \& Wildlife, Oregon State University, 200 SW 35th Street, Corvallis, OR, 97333, USA

4 Current affiliation: Amnis Opes Institute, 2895 SE Glenn Street, Corvallis, OR 97333, USA

5 Institute of Hydrobiology and Aquatic Ecosystem Management, Dept. of Water, Atmosphere and Environment, BOKU - University of Natural Resources and Applied Life Sciences, Max-Emanuel-Strasse 17, 1180 Vienna, Austria

6 US Geological Survey, Leetown Science Center, Aquatic Ecology Branch, 11649 Leetown Road, Kearneysville, WV 25430, USA

7 National Institute for Environmental Studies, Onogawa 16-2, Tsukuba, Ibaraki 305-8506, Japan

\begin{abstract}
Identifying and quantifying relationships among landscape patterns, anthropogenic disturbances, and aquatic ecosystems is a new and rapidly developing approach to riverine ecology. In this review, we begin by describing the policy and management drivers for landscape-scale riverine research and we synthesize the technological advances that have enabled dramatic progress in the field. We then describe the development of landscape-scale riverine research through a series of landmark theoretical and review papers. Focusing on landscape-fish relationships, we consider the degree to which past efforts have been successful at meeting three challenges: (1) Has new research effectively incorporated the strengths of new technologies or are we doing the same old thing with more expensive data? (2) Have we incorporated key concepts from landscape ecology to improve our understanding of how landscapes affect rivers? (3) Have we been able to use landscape analyses to address management and policy needs? We conclude with a review of opportunities for advancement in the field of landscape-scale riverine research. These include moving toward the development of mechanistic theories of how landscapes affect rivers across disparate regions; considering the spatio-temporal structure of human impacts to landscapes; harnessing new statistical tools; and carefully defining landscape and response metrics to capture specific features.
\end{abstract}

Keywords: Aquatic ecosystems, Riverine ecology, Landscape patterns, River management, Catchment scale, Watershed scale

This review is licensed under a Creative Commons Attribution-Non-Commercial-NoDerivs 3.0 Germany License. http://creativecommons.org/licenses/by-nc-nd/3.0/de/ 


\section{Imprint / Terms of Use}

Living Reviews in Landscape Research is a peer reviewed open access journal published by the Leibniz Centre for Agricultural Landscape Research (ZALF), Eberswalder Straße 84, 15374 Müncheberg, Germany. ISSN 1863-7329.

This review is licensed under a Creative Commons Attribution-Non-Commercial-NoDerivs 3.0 Germany License: http://creativecommons.org/licenses/by-nc-nd/3.0/de/

Because a Living Reviews article can evolve over time, we recommend to cite the article as follows:

E. Ashley Steel, Robert M. Hughes, Aimee H. Fullerton, Stefan Schmutz, John A. Young, Michio Fukushima, Susanne Muhar, Michaela Poppe, Blake E. Feist and Clemens Trautwein,

"Are We Meeting the Challenges of Landscape-Scale Riverine Research? A Review", Living Rev. Landscape Res., 4, (2010), 1. [Online Article]: cited [<date $>$ ], http://www.livingreviews.org/lrlr-2010-1

The date given as $<$ date $>$ then uniquely identifies the version of the article you are referring to.

\section{Article Revisions}

Living Reviews supports two ways of keeping its articles up-to-date:

Fast-track revision A fast-track revision provides the author with the opportunity to add short notices of current research results, trends and developments, or important publications to the article. A fast-track revision is refereed by the responsible subject editor. If an article has undergone a fast-track revision, a summary of changes will be listed here.

Major update A major update will include substantial changes and additions and is subject to full external refereeing. It is published with a new publication number.

For detailed documentation of an article's evolution, please refer to the history document of the article's online version at http://www.livingreviews.org/lrlr-2010-1. 


\section{Contents}

1 Introduction $\quad 5$

2 Drivers of large-scale riverine research $\quad 6$

2.1 Policy drivers . . . . . . . . . . . . . . . . . . . . . . . . . . . . . . . . . . . . . . . . . .

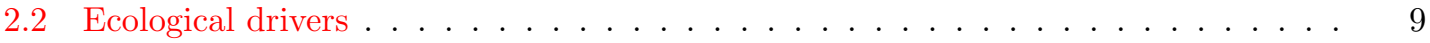

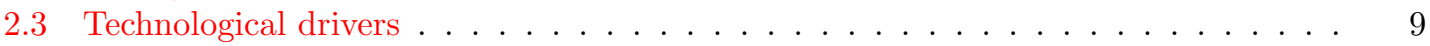

3 Conceptual history of landscape-scale riverine research 12

4 Challenges to landscape riverine research $r$

4.1 Has new research utilized the strengths of new technologies or are we doing the same old stuff with more expensive data? . . . . . . . . . . . . . . 16

4.2 Have we incorporated key concepts from landscape ecology to improve our understanding of how landscapes affect rivers? . . . . . . . . . . . . . . . 18

4.3 Have we been able to use landscape analyses to address management and policy

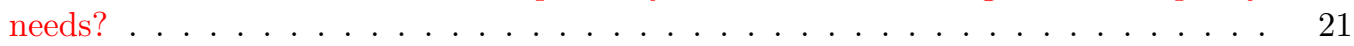

5 Opportunities in landscape-scale riverine research $\quad 26$

5.1 Moving toward mechanism . . . . . . . . . . . . . . . . . . . 26

5.2 Spatio-temporal structure of human impacts . . . . . . . . . . . . . . . 27

5.3 Statistical opportunities . . . . . . . . . . . . . . . . . . . . . . . . . . . . . . . . . . . . . . . . . . .

5.4 Defining the right metrics . . . . . . . . . . . . . . . . . . . . 29

6 Conclusions $\quad 30$

7 Acknowledgements $\quad 31$

A Appendix: Landscape perspectives of rivers $\quad 32$

$\begin{array}{lr}\text { References } & 36\end{array}$

\section{List of Tables}

1 Examples of policy and management drivers of landscape-scale approaches with region or country in parentheses. . . . . . . . . . . . . . . . . . . . 7

2 Principal mechanisms by which land use influences stream ecosystems. . . . . . . . 14

3 Environmental variables associated with fish distribution, classified by system attribute and observational scale. . . . . . . . . . . . . . . . . . 15 



\section{Introduction}

Riverine networks are intricately linked to the landscapes through which they flow (Hynes, 1975) (see Appendix A) and it is widely accepted that riverine management should occur over whole watersheds (Naiman et al., 1992; Frissell et al., 1986). Many fundamental theories and models in river ecology have their bases in landscape-scale thinking. While some approaches are naturally borrowed from the field of landscape ecology (see Section 4.2), we assert that much of the research linking landscapes to rivers has arisen relatively independently. For example, the river continuum concept (Vannote et al., 1980) considers changes in carbon processing and biota with increasing drainage area across entire riverscapes. Sediment routing and nutrient models (see Zweimüller et al., 2008; Tetzlaff et al., 2007) incorporate vegetation type, soil conditions, land use, and lithology over large areas. In this review, we focus on how landscape influences on rivers, and in particular on fish assemblages, have been and can be measured, quantified, and applied to freshwater management problems; we draw on examples from multiple continents.

In Section 2 of this review, we summarize the policy and management drivers for landscape-scale riverine research, remind readers of the ecological drivers, and synthesize the technological advances that have enabled dramatic progress in the field. In Section 3, we describe the development of landscape-scale riverine research through a series of landmark theoretical and review papers. In our Section 4, we consider three important questions with respect to landscape-scale riverine research:

- Has new research effectively incorporated the strengths of new technologies or are we doing the same old thing with more expensive data?

- Have we incorporated key concepts from landscape ecology to improve our understanding of how landscapes affect rivers?

- Have we been able to use landscape analyses to address management and policy needs?

We synthesize existing literature to answer these questions and, in so doing, review progress to date. In Section 5, we use our review to identify opportunities for future efforts.

The roots of landscape-scale riverine research lie not in process-based models or mechanistic research, as in watershed ecology, but in the evaluation of pattern using statistical or correlative models, guided by mechanistic principles. Such analyses necessarily draw heavily on concepts from both river ecology and landscape ecology. Ideas commonly explored in these analyses include correlations between particular land uses and instream conditions, the impact of geographic extent on the strength of these correlations, and the degree to which local relationships between predictor and response variables at a large numbers of sites can be aggregated at larger scales. We define scale as the grain (resolution) and extent of both the predictor variables (generally measures of landscape condition) and the response variables (measures of instream condition and biological response).

We differentiate landscape-scale riverine research from traditional river ecology, riparian ecology, or watershed ecology by (i) the large spatial extent of the analyses, (ii) the use of spatial databases, and (iii) the emphasis on how landforms and land use outside of the active channel or the riparian area affect streams and rivers (Figure 1). We limit ourselves in this review to research that includes all three of the above features and to projects that consider fish as the biological response of interest. Except for a few examples, we exclude the diverse and important research concerning landscape-scale impacts on other instream biological responses, on physical and chemical habitat, and on terrestrial or marine biota. 


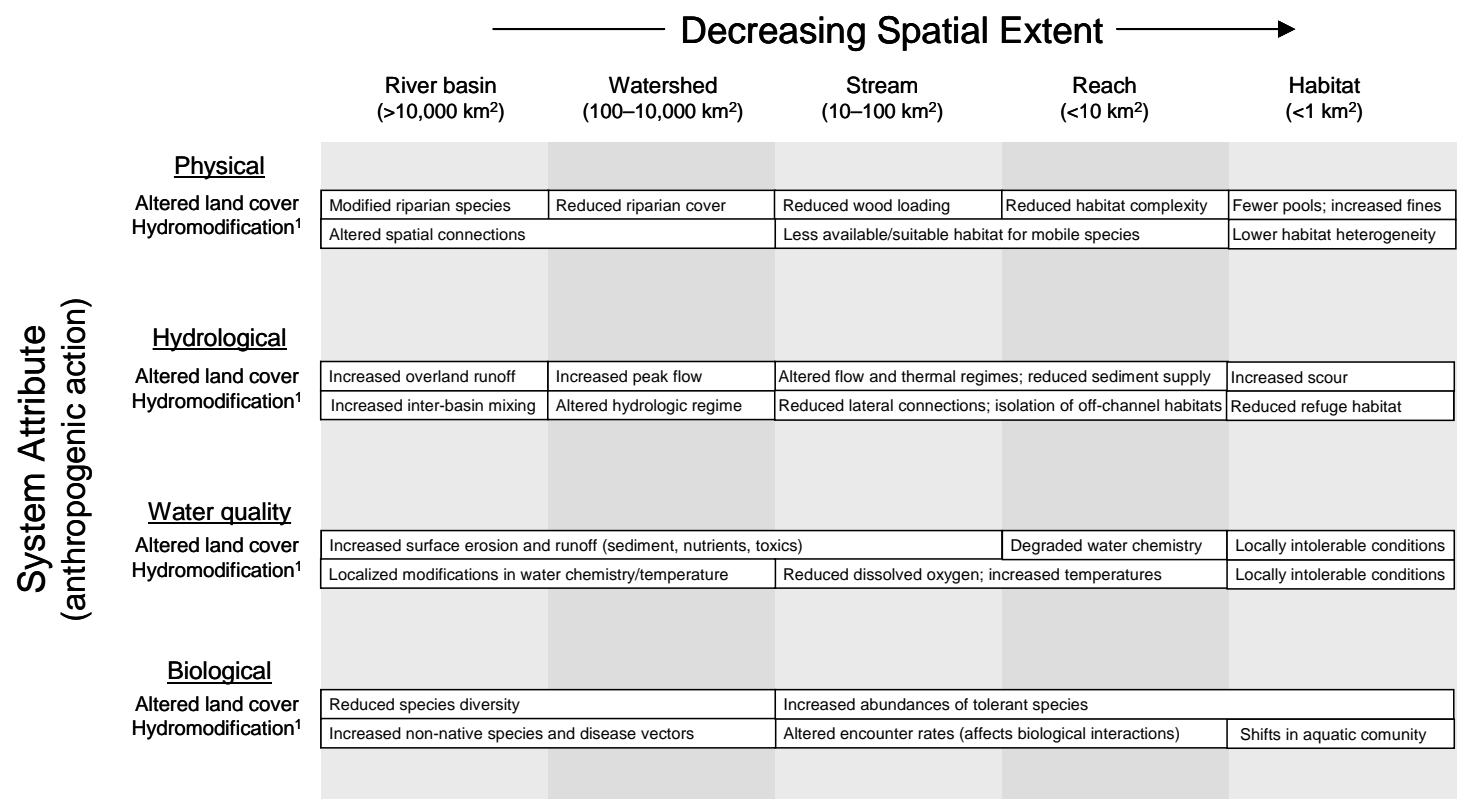

Figure 1: Anthropogenic impacts, including altered land cover and hydromodification, drive physical, hydrological, chemical, and biological riverine response at the basin scale; these changes trickle down through the watershed scale, the stream scale and finally to reach-scale impacts on habitat and biota.

${ }^{1}$ Hydromodification includes anything that modifies/disrupts the flow of water or aquatic animals (i.e., dams, culverts, weirs, armored banks, levees, ditches).

\section{Drivers of large-scale riverine research}

\subsection{Policy drivers}

Management and conservation of aquatic habitats and their biota are often subject to new or adapted legal frameworks that rely on large-scale analyses. These legal frameworks may result from multiple issues such as the need for flood protection, aquatic ecosystem/water protection, nature/endangered species conservation, land use planning or conversion, rural development, or agricultural management. Meeting the needs of environmental legislation (Table 1) has pushed managers and policy-makers to demand landscape-scale products. Such products include estimates of habitat capacity for endangered species across vast areas of the Pacific Northwest (PNW) USA (e.g., Carmichael and Taylor, 2010; Burnett et al., 2007), modeled estimates of river condition across the European Union (EU) (e.g., Pont et al., 2006), or rigorous assessments of water body status and trends across the western USA (e.g., Pont et al., 2009; Stoddard et al., 2005) and the conterminous USA (e.g., USEPA, 2009; Paulsen et al., 2008). Large-scale, multi-million dollar rehabilitation projects such as those being implemented in the U.S. for Chesapeake Bay, San Francisco Bay, south Florida, or entire states (e.g., Ohio and Oregon) require landscape-scale monitoring and analyses (Independent Multidisciplinary Science Team, 2007). Conforming to these directives and monitoring the effectiveness of large-scale restoration has created a "window of opportunity" for increased research at the landscape scale and for landscape perspectives to affect on-the-ground management (Hughes et al., 2008).

The European Water Framework Directive (WFD), implemented in 2000, is an example of a relatively new policy directive that promotes landscape-scale analyses and management. It demands that all water bodies across Europe achieve good ecological status or good ecological

Living Reviews in Landscape Research

http://www. livingreviews.org/lrlr-2010-1 
Table 1: Examples of policy and management drivers of landscape-scale approaches with region or country in parentheses (modified from Hughes et al., 2008). See Section 2.1 for descriptions of policies.

\begin{tabular}{|c|c|c|c|}
\hline Forces for change & Management needs & Law/Directives & $\begin{array}{l}\text { Examples of } \\
\text { landscape-scale re- } \\
\text { sponse }\end{array}$ \\
\hline Floods, climate change & $\begin{array}{l}\text { Flood protection, wa- } \\
\text { ter storage }\end{array}$ & $\begin{array}{l}\text { Flood Protection Di- } \\
\text { rective (Europe); The } \\
\text { River Law (Japan) }\end{array}$ & $\begin{array}{l}\text { Prioritization of ar- } \\
\text { eas for flood retention, } \\
\text { flood risk manage- } \\
\text { ment. }\end{array}$ \\
\hline $\begin{array}{l}\text { Degraded aquatic } \\
\text { ecosystems includ- } \\
\text { ing altered hydromor- } \\
\text { phology and decreased } \\
\text { water availability }\end{array}$ & $\begin{array}{l}\text { Aquatic ecosys- } \\
\text { tem/water protection } \\
\text { and storage }\end{array}$ & $\begin{array}{l}\text { Water Framework } \\
\text { Directive (Europe), } \\
\text { Clean Water Act } \\
\text { (USA), Endangered } \\
\text { Species Act (USA), } \\
\text { Manuelzão Project } \\
\text { (Brazil), Environment } \\
\text { Protection \& Biodiver- } \\
\text { sity Conservation Act } \\
\text { (Australia), Species at } \\
\text { Risk Act (Canada), } \\
\text { Constitutional Rights } \\
\text { of Nature (Ecuador), } \\
\text { Ramsar Convention on } \\
\text { Wetlands (Iran) }\end{array}$ & $\begin{array}{l}\text { Protection and en- } \\
\text { hancement of the sta- } \\
\text { tus of aquatic ecosys- } \\
\text { tems and, with regard } \\
\text { to their water needs, } \\
\text { terrestrial ecosys- } \\
\text { tems and wetlands } \\
\text { directly depending on } \\
\text { the aquatic ecosys- } \\
\text { tems. }\end{array}$ \\
\hline $\begin{array}{l}\text { Decreasing biodiversity } \\
\text { / increasing number } \\
\text { of threatened/extinct } \\
\text { species/habitats, in- } \\
\text { creased numbers of } \\
\text { invasive species }\end{array}$ & Nature conservation & $\begin{array}{l}\text { Habitat and Birds Di- } \\
\text { rective (Europe), En- } \\
\text { dangered Species Act } \\
\text { (USA), Manuelzão } \\
\text { Project (Brazil), En- } \\
\text { vironment Protection } \\
\text { \& Biodiversity Con- } \\
\text { servation Act (Aus- } \\
\text { tralia), Species at Risk } \\
\text { Act (Canada), Con- } \\
\text { stitutional Rights of } \\
\text { Nature (Ecuador) }\end{array}$ & $\begin{array}{l}\text { Political commitment } \\
\text { to halt biodiversity } \\
\text { loss within the EU by } \\
2010 \text {. Establishment } \\
\text { of a coherent network } \\
\text { of protected areas. } \\
\text { Guarantee ecological } \\
\text { requirements of the } \\
\text { natural habitat types } \\
\text { and species of commu- } \\
\text { nity interest. Nature } \\
\text { protection. }\end{array}$ \\
\hline $\begin{array}{l}\text { Linkage of flooding } \\
\text { events to land use }\end{array}$ & $\begin{array}{l}\text { Land use planning, } \\
\text { discourage floodplain } \\
\text { occupation by humans }\end{array}$ & $\begin{array}{l}\text { European Spatial De- } \\
\text { velopment Perspective } \\
\text { (Europe) }\end{array}$ & $\begin{array}{l}\text { Concentrating/clustering } \\
\text { land use types ac- } \\
\text { cording to their flood } \\
\text { tolerance. Maintaining } \\
\text { and re-activating } \\
\text { natural flood retention } \\
\text { areas. }\end{array}$ \\
\hline Spatial disparities & Rural development & $\begin{array}{l}\text { EU Rural Develop- } \\
\text { ment Regulations (Eu- } \\
\text { rope) }\end{array}$ & $\begin{array}{l}\text { Integrated approaches } \\
\text { to sustainable rural } \\
\text { development. }\end{array}$ \\
\hline $\begin{array}{l}\text { Health concerns, food } \\
\text { supply, environmental } \\
\text { degradation, ecosys- } \\
\text { tem services }\end{array}$ & Agriculture, fisheries & $\begin{array}{l}\text { Reformed common } \\
\text { agricultural policy } \\
\text { Agenda } 2000(\mathrm{Eu}- \\
\text { rope); Farm Bill } \\
\text { (USA) }\end{array}$ & $\begin{array}{l}\text { A long-term perspec- } \\
\text { tive for sustainable } \\
\text { agriculture and fish- } \\
\text { eries; riparian/stream } \\
\text { protection }\end{array}$ \\
\hline
\end{tabular}


potential by the year 2015 or, at the latest extension of the deadline, by 2027 (Water Framework Directive, 2000). These assessments are required for every stream and river in Europe and can be based on empirical or modeled data. The WFD specifically addresses impacts of catchmentscale land use on, for example, diffuse pollution in riverine systems. "Land use patterns, including identification of the main urban, industrial and agricultural areas and, where relevant, fisheries and forests" must be estimated (WFD Article 5 and Annex II) during the identification of human impacts in each catchment. Additionally, River Basin Management Plans (RBMP), required for all catchments, should include an "estimation of diffuse source pollution, including a summary of land use" (WFD, Article 13 and Annex VII). Because of these specific requirements, the WFD institutionalizes a large-scale approach to river research and management that requires coordination of activities such as monitoring, rehabilitation prioritization, planning, and public consultation across vast extents (Steyaert and Ollivier, 2007; Moss, 2004).

The WFD is not the only policy that promotes landscape-scale research and management across Europe. The Habitats Directive (1992) and the Birds Directive (1979) mandate a landscape approach to conservation planning that goes well beyond the traditional research scales of individual habitats and river reaches, even beyond political boundaries and frontiers. Such large-scale thinking is also reflected in the International Commission for the Protection of the Danube River (ICPDR), which focuses on the management of land including the built environment. The Natura 2000 network of conservation sites is yet another European example of a very large-scale conservation program and new policies continue to expand its scope.

There are policy drivers for landscape-scale analyses in other regions. One of the primary drivers of landscape-scale riverine research in the USA has been the Endangered Species Act (ESA; Public Law (PL) 92-205, 16 United States Code (USC) 1531 et seq. 1973). The ESA provides for the conservation of ecosystems upon which threatened and endangered species of fish, wildlife, and plants depend. Under this Act, twenty-seven evolutionarily significant units (ESUs) of anadromous Pacific salmonids, including Chinook, chum, coho, sockeye, and steelhead trout, have been listed as threatened or endangered since 1991. The cumulative area (spanning portions of the states of Washington, Oregon, Idaho, and California) of ESUs with one or more listed species is approximately $372,000 \mathrm{~km}^{2}$ and encompasses thousands of kilometers of stream. To complicate matters, these fish use a wide variety of stream habitat types often spawning in low gradient habitats, rearing in smaller streams, and migrating through urbanized mainstem rivers. As a result of the ESA and the listing of Pacific salmonids over such vast extents, a critical need has arisen for estimation and prediction of species distributions and environmental conditions over large areas for which adequate field data do not exist. The Species at Risk Act adopted in Canada in 2002 serves a purpose similar to the Endangered Species Act and has promoted large-scale thinking about aquatic systems across Canada (http://laws.justice.gc.ca/eng/S-15.3/).

A second key policy driver across the USA is the Federal Water Pollution Control Act, commonly referred to as the Clean Water Act (CWA, PL 92-500, 33 USC 2101 et seq. 1948). The purpose of the CWA is to restore and maintain the chemical, physical, and biological integrity of the nation's waters. As a result, the US Environmental Protection Agency (USEPA) is involved in a wide range of monitoring and analysis programs that consider impacts of land use over large spatial extents on the health and condition of surface waters (lakes, streams, rivers, estuaries, coastal waters, wetlands). These programs are designed to answer questions such as: What is the current extent of the waters that support healthy ecosystems? Is water quality improving? What are the key stressors that account for waters with poor biological condition? The evolution of CWA programs over the last decade has included a shift toward watershed-based TMDL strategies (Total Maximum Daily Loads; http://www.epa.gov/watertrain/cwa/) and rotating probabilistic surveys of all USA surface waters on an annual basis (e.g., USEPA, 2009; Paulsen et al., 2008; Shapiro et al., 2008).

Japan is experiencing a similar shift toward riverine policy directives that promote a landscape-

Living Reviews in Landscape Research

http://www. livingreviews.org/lrlr-2010-1 
scale perspective. The River Law in Japan was originally designed solely for flood protection and water use but, in 1990, Japan launched "Nature-Oriented River Work" or "Ta Shizen Gata Kawa Zukuri," which is an initiative aimed at conserving beautiful landscapes and riverine biodiversity. The trend toward increasing spatial extents in river conservation continued when the River Law was amended in 1997 to add "Conservation and Improvement of River Environments" as a third purpose of the law. These policies are expected to serve as a comprehensive and systematic plan to protect biodiversity and rehabilitate fluvial environments and ecosystems. One practical outcome of this strategy is the National Census on River Environment, which provides periodic surveys of the status of rivers and dams from an environmental perspective (e.g., fish survey) over large areas.

Beyond Europe, North America, and Japan, the trend toward large-scale conservation is also strong. The Ramsar Convention on Wetlands, signed in Iran in 1971 promotes a landscape perspective. In one of the latest resolutions (Resolution IX.I, Annex C) of this convention, it is stated that "management and development of wetlands must be undertaken within the context of their larger surrounding 'waterscape' (the river basin or catchment, including the hydrological processes and functions within the basin or catchment) as well [as] their larger surrounding landscape" (http://www.ramsar.org/pdf/lib/lib_handbooks2006_e07.pdf). Similar conditions led to the initiation of the River Health Program (RHP) in South Africa in 1994. The RHP objectives are to monitor and report on aquatic ecosystem status, trends, and emerging problems of South African rivers (Kleynhans, 1999; Murray, 1999). In Australia, over-allocation of water coupled with a longterm shift to a drought regime resulting from climate change have stimulated a Sustainable Rivers Audit Program to monitor conditions across the nation's major river basins (Davies et al., 2006). In Brazil, the Manuelzão Project is directed toward public education, wastewater treatment, land and water use, and ecological monitoring across the entire Rio das Velhas Basin (Lisboa et al., 2008). Brazil has also recently passed progressive environmental protection laws designed to protect the nation's rich natural resources, especially its water quality and biodiversity, and has established national parks to protect biodiversity and the recovery of large tracts of riparian corridors in many areas (Drummond and Barros-Platiau, 2006). Ecuador recently adopted a new constitution that formally recognizes the rights of nature "to exist, persist, maintain and regenerate its vital cycles, structure, functions and its processes in evolution" (http://celdf.org/article.php?id=712).

\subsection{Ecological drivers}

The nature of current conservation concerns has clearly necessitated a landscape-scale approach to a wide range of riverine issues (Table 1). A summary of all current conservation concerns is beyond the scope of this review; we simply remind readers of the large spatial extent of current issues. Managing watersheds, stream habitats, and fisheries in the face of climate change will, for example, require spatially extensive approaches to monitoring, data collection and analysis. Non-indigenous species continue to pose major threats to aquatic ecosystems (Leprieur et al., 2008b; Lomnicky et al., 2007; Miller Reed and Czech, 2005). Aquatic non-indigenous species range over very large areas and efforts to limit their spread or estimate their impacts must necessarily incorporate data collection and analysis techniques at the landscape scale (e.g., Sanderson et al., 2009). Increasing awareness of and concern about these threats provides a second "window of opportunity" for comprehensive, large-scale river research (Hughes et al., 2008).

\subsection{Technological drivers}

The incorporation of landscape thinking into riverine research has been catapulted by the availability of new technologies (Johnson and Host, 2010; Johnson and Gage, 1997). Habitat assessments in the past were necessarily transect-based and field intensive. Research and analyses had to proceed by sampling discrete reaches of very large, diverse, and dynamic systems. Therefore, despite 
conceptual models that placed streams in their landscape context (e.g., Schlosser, 1991; Vannote et al., 1980; Hynes, 1975), aquatic research methods have historically been focused on individual stream reaches.

Aerial photography, in use since the 1940s, was the first technology to provide a landscape-scale perspective but a suite of recent new technologies has dramatically improved our ability to conduct research over large areas. High spatial resolution (e.g., 1-meter pixel resolution) digital imagery provides powerful new tools for riverine landscape mapping and feature identification. Remote sensing has previously enabled synoptic views of entire rivers and their catchments and can now provide data at resolutions that capture reach-scale riparian and instream habitat structuring (Hall et al., 2009; Silva et al., 2008; Legleiter, 2003; Sawaya et al., 2003; Leuven et al., 2002; Marcus, 2002). Geographic Information Systems (GIS) have made landscape pattern analysis possible. As well, digital terrain modeling has provided tools for defining catchment boundaries and stream flow in flexible and easily repeatable ways.

Spatial data can describe relatively immutable natural conditions such as elevation, geology, soil type, air temperature, and precipitation. Spatial data are also available to describe anthropogenic stressors such as road density, land use, urbanization, migration barriers, water withdrawals, dams, and mine claim density. Mertes (2002) provided a comprehensive review of remote sensing advances and their applications to riverine environments, and discussed the newly arising capabilities to examine "spatial and temporal relationships among biota, hydrology, and geomorphology across scales from microhabitats to channel units to valleys to catchments". Mertes (2002) surveyed the increasing variety of sensing technologies available for mapping both landscape and water properties including optical sensors, light detection and ranging (LiDAR), forward looking infrared (FLIR), and radio detection and ranging (RADAR), deployed from multiple platforms from low altitude tethered balloons, to helicopter and fixed wing aircraft, to satellites. These new techniques allow us to capture information with a high degree of both lateral and longitudinal resolution. It is now also possible to directly sense water properties including elevation of the water surface, width of flooded area, distribution of wood, surface temperature, turbidity, and sediment movement (Smikrud et al., 2008; Smikrud and Prakash, 2006; Mertes, 2002). And, we can generate stream network maps at much finer scales using LiDAR-based digital elevation models (DEM) than with satellite generated data (Mouton, 2005) as well as bathymetric delineations (Jones et al., 2008; McKean et al., 2008).

In addition to advances in spatial resolution, new sensors have increased spectral resolution. "Hyperspectral" sensors image in hundreds of finely defined wavelength bands, in contrast to the 3-6 broadly defined wavelength bands of color aerial photography and multispectral land imaging satellites (e.g., Landsat, SPOT). Legleiter et al. (2002) and Marcus (2002) compared capabilities of multi- and hyperspectral sensors for mapping instream features and both found that higher spectral and spatial resolutions increased mapping accuracies over lower resolution data. One outcome of these studies was the interesting prospect that mapping from high-resolution hyperspectral imagery might be more accurate than field based mapping (Marcus, 2002). Datasets generated from hyperspectral imagery have more stringent requirements for accurate preprocessing and require increasingly sophisticated classification techniques (Aspinall et al., 2002; Wulder et al., 2004); however, the spatial and spectral resolution provided by high-resolution hyperspectral systems is opening new avenues for ecosystem mapping, including mapping aquatic habitat features in both large and small streams (Figure 2). Traditional reach-based models, for example, have been limited in their ability to represent lateral habitat features but, using these new techniques, we can now map floodplains and large rivers accurately across two and even three dimensions (Kinzel, 2009).

Living Reviews in Landscape Research

http://www. livingreviews.org/lrlr-2010-1 


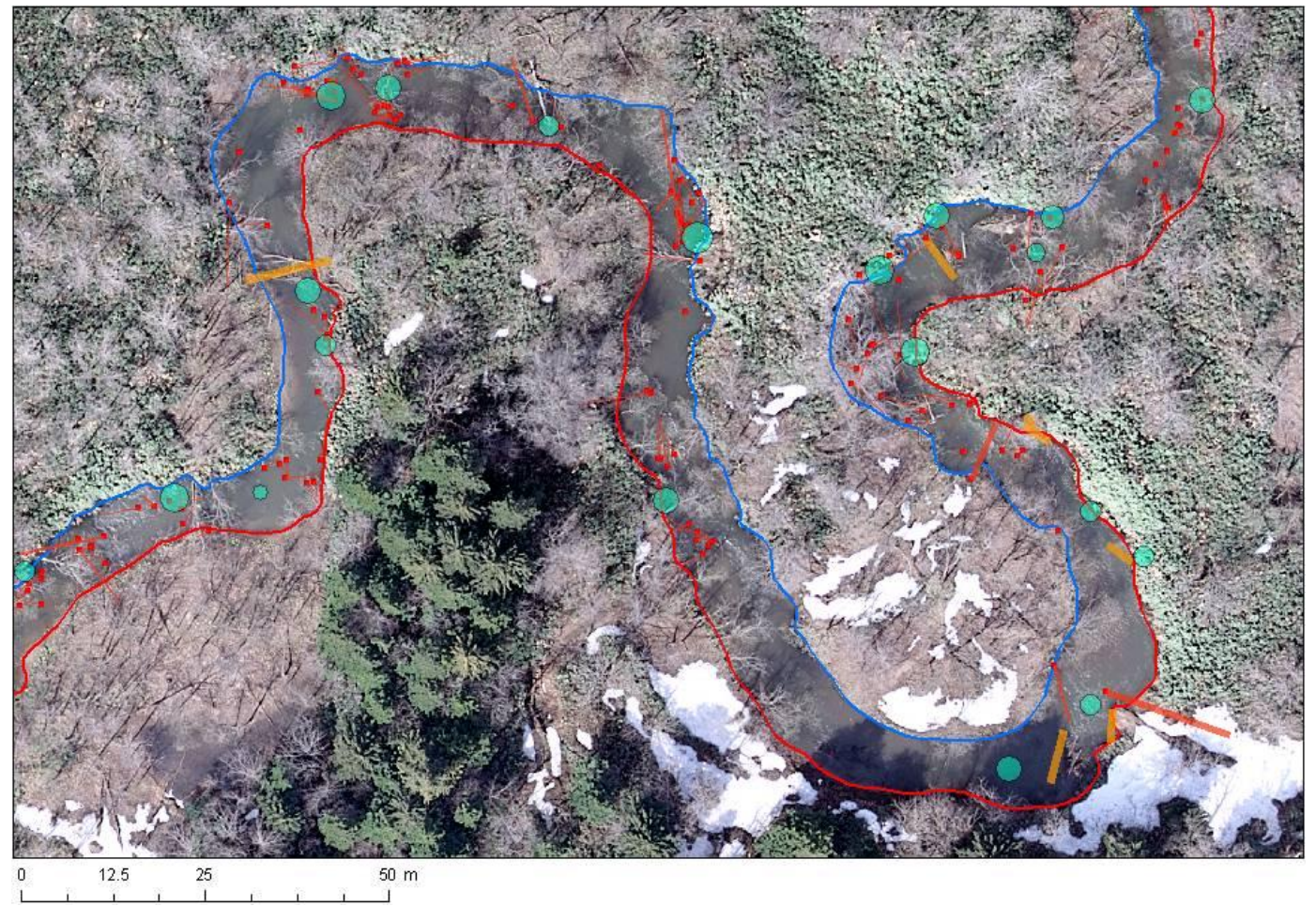

Figure 2: Aerial photo of a tributary of the Sarufutsu River, Japan, by DMC (digital mapping camera). Field-validated instream features such as woody debris (red lines), log jam (thick orange line), and deep pools (green circles) are superimposed. The field mapping of these features closely matches the photo imagery. 


\section{Conceptual history of landscape-scale riverine research}

A series of landmark papers has developed the conceptual framework for landscape-scale riverine research. Hynes (1975) described the complex interactions linking terrestrial and aquatic ecosystems. Vannote et al. (1980) provided a coherent framework from which to predict and understand how interactions between terrestrial and aquatic ecosystems control instream processes and how these interactions change in a predictable way from forested headwater streams to mainstem rivers. Frissell et al. (1986) described how climate, geology, and land form provide a series of nested controls through which instream habitats are shaped and maintained, and to which biota respond. Ward (1989) described the four-dimensional nature of river ecosystems and the importance to aquatic biota and processes of maintaining those connections across landscapes and through time. Tonn (1990) offered a conceptual framework outlining how continental, regional, water body type, and local environmental processes and features (filters) govern fish assemblage patterns across all those spatial extents. Schlosser (1991) emphasized the importance of spatial and temporal heterogeneity and connectivity to river ecosystems and their biota. And, Hawkins et al. (1993) promoted the concept of hierarchical drivers of stream habitat features. Poff (1997) added a framework for using explicit multi-scale landscape constraints to predict and understand distribution, abundance, and local assemblage composition. Ward (1998) described the pathways by which landscape disturbances organize and constrain instream habitats. The next conceptual leap came from Fausch et al. (2002), who promoted the need for a continuous view of rivers and encouraged researchers and managers not to view the river as a series of disjoint reaches but to consider "the entire spatially heterogeneous scene of the river environment, the riverscape, unfolding through time." Burcher et al. (2007) applied the concept of an ecological cascade or series of impacts to understand how land-cover change can alter biological responses. Building on earlier ideas in which processes of higher scales form boundary conditions for lower scales (Angermeier and Winston, 1999), they proposed the land cover cascade as a conceptual framework for organizing the diverse relationships between landscape-scale phenomena and instream biological responses.

These theoretical frameworks have supported a large body of research to understand and to quantify interactions between landscape conditions over large spatial extents and instream responses. A series of review papers and research compendia organizes and tracks growth in the field of landscape riverine research.

A special issue of Freshwater Biology (1997) first began to assemble the ideas and findings of this new perspective on river systems. Johnson and Gage (1997) reviewed the state of the art at the time. They concluded that the advent of GIS technologies and the need for wide-ranging policies and management programs had pushed landscape-scale research to the forefront of riverine ecology. They synthesized the landscape metrics in common use for landscape analysis and the statistical tools available for linking landscape patterns to instream conditions. Johnson and Gage concluded that these new spatial and statistical tools have enabled ecologists to study patterns and relationships over larger and more diverse extents than previously possible. Other papers in the special issue compared local versus landscape perspectives on Michigan trout streams (Wiley et al., 1997), examined the role of catchment land use patterns on stream integrity (Allan and Johnson, 1997), land use on macroinvertebrate assemblages in New Zealand (Townsend et al., 1997), landscape condition on water chemistry (Johnson and Gage, 1997), and multi-scale impacts on species traits of macroinvertebrate assemblages (Richards et al., 1997).

A second set of papers was assembled in Freshwater Biology in response to the First International Symposium on Riverine Landscapes. In that special issue, Wiens (2002) promoted the direct application of concepts from the field of landscape ecology, which had traditionally focused on terrestrial landscapes, to aquatic systems. Papers in the special issue described linkages between landscapes and both hydrogeomorphic processes (Poole, 2002) and biological responses (Malmqvist, 2002), detailed advances in remote sensing and GIS technologies (Mertes, 2002) and

Living Reviews in Landscape Research

http://www. livingreviews . org/lrlr-2010-1 
applied landscape concepts to riverine management (Poudevigne et al., 2002).

A comprehensive and detailed review of research linking land use to instream conditions was recently provided by Allan (2004a). He outlined pathways by which land use at the catchment and riparian scales affects instream habitats (Table 2) and synthesized over 100 research papers correlating land use with metrics of stream health. Allan found that the most common landscape composition metric in studies linking land use and land cover to aquatic response has been the percentage of land cover types in either the catchment or the riparian area. Across multiple projects, he was able to conclude that a high proportion of forest cover in a catchment is normally associated with positive stream conditions. Conversely, agricultural or urban areas in the catchment have been documented to have a negative influence on downstream river conditions (Allan, 2004a). Allan (2004b) also raised several key challenges to linking landscapes and the ecological status of rivers.

Durance et al. (2006) reviewed 658 papers dealing with the management of fish in rivers and found that only 27 explicitly considered the impact of scale. They were able to summarize some catchment-scale pathways by which landscapes affect fish abundance and distribution such as climate, geology, vegetation, and past land use (Table 3) (Durance et al., 2006).

In 2006, a large volume of research exploring and quantifying landscape influences on stream habitats and biological assemblages was assembled by Hughes et al. (2006b). This collection of 30 research papers focused on research linking catchment-scale landscape condition to instream habitat and fish responses. The editors concluded that there were four key challenges in studying river systems in a landscape context: determining appropriate units for measuring and interpreting the riverscape, understanding the mechanisms by which land use alters river habitats and biota, measuring and understanding how spatial factors interactively affect aquatic habitats and biota, and collecting and interpreting appropriate landscape and riverine data. Major knowledge gaps requiring additional research included improving river-landscape classification, determining the appropriate spatial and temporal scales at which data should be captured, improving predictive models where data are limited, and improving our measures of connectivity among river networks and their landscapes.

Most recently, Johnson and Host (2010) reviewed the landscape-aquatic literature from 1986 to 2008 , revealing a 20 -fold increase in the number of publications over that time. They also found that as the scales of the studies increased so did the importance of landscape versus sitescale predictors. Because of the use of varied terms and extents for 'site' and 'landscape', they recommended that editors demand explicit descriptions of both. In the same issue, Poole (2010) pointed out that stream hydrogeomorphology is also at the roots of riverine landscape ecology by providing mechanistic foundations for how fluvial landscapes shape stream ecosystems. 
Table 2: Principal mechanisms by which land use influences stream ecosystems (modified from Allan, 2004a).

\begin{tabular}{|c|c|}
\hline $\begin{array}{l}\text { Environmental } \\
\text { factor }\end{array}$ & Effects \\
\hline Sedimentation & $\begin{array}{l}\text { Increases turbidity, scouring and abrasion; impairs substrate suitability } \\
\text { for periphyton and biofilm production; decreases primary production and } \\
\text { food quality causing bottom-up effects through food webs; in-filling of } \\
\text { interstitial habitat harms crevice-occupying invertebrates and gravel- } \\
\text { spawning fishes; coats gills and respiratory surfaces; reduces stream } \\
\text { depth heterogeneity, leading to decrease in pool species. }\end{array}$ \\
\hline Nutrient enrichment & $\begin{array}{l}\text { Increases autotrophic biomass and production, resulting in changes to } \\
\text { assemblage composition, including proliferation of filamentous algae, par- } \\
\text { ticularly if light also increases, accelerates litter breakdown rates and } \\
\text { may cause decrease in dissolved oxygen and shift from sensitive species } \\
\text { to more tolerant, often non-native species. }\end{array}$ \\
\hline Toxic chemicals & $\begin{array}{l}\text { Increases heavy metals, synthetics, and toxic organics in suspension as- } \\
\text { sociated with sediments and in tissues; increases deformities; increases } \\
\text { mortality rates and alters abundance, drift, and emergence of inverte- } \\
\text { brates; depresses growth, reproduction, condition, and survival among } \\
\text { fishes; disrupts endocrine system; physical avoidance. }\end{array}$ \\
\hline $\begin{array}{l}\text { Hydrologic alter- } \\
\text { ation }\end{array}$ & $\begin{array}{l}\text { Alters runoff-evapotranspiration balance causing increases in flood mag- } \\
\text { nitude and frequency, and often lowers base flow; contributes to altered } \\
\text { channel dynamics, including increased erosion from channel and sur- } \\
\text { roundings and less-frequent overbank flooding; runoff more efficiently } \\
\text { transports nutrients, sediments, and contaminants, thus further de- } \\
\text { grading in-stream habitat. Strong effects from impervious surfaces and } \\
\text { stormwater conveyance in urban catchments and from drainage systems } \\
\text { and soil compaction in agricultural catchments. Dams can alter flow pat- } \\
\text { terns, removing natural fluctuations that produce channel complexity } \\
\text { and/or producing sudden unnatural fluctuations. }\end{array}$ \\
\hline $\begin{array}{l}\text { Riparian clearing / } \\
\text { canopy opening }\end{array}$ & $\begin{array}{l}\text { Reduces shading, causing increases in stream temperatures, light pene- } \\
\text { tration, and plant growth; decreases bank stability, inputs of litter and } \\
\text { wood, and retention of nutrients and contaminants; reduces sediment } \\
\text { trapping and increases bank and channel erosion; alters quantity and } \\
\text { character of dissolved organic carbon reaching streams; lowers reten- } \\
\text { tion of benthic organic matter owing to loss of direct input and retention } \\
\text { structures; alters trophic structure. }\end{array}$ \\
\hline $\begin{array}{l}\text { Loss of large woody } \\
\text { debris }\end{array}$ & $\begin{array}{l}\text { Reduces substrate for feeding, attachment, and cover; causes loss of sedi- } \\
\text { ment and organic material storage, reduces energy dissipation; alters flow } \\
\text { hydraulics and therefore distribution of habitats; reduces bank stability; } \\
\text { influences invertebrate and fish diversity and community function. }\end{array}$ \\
\hline
\end{tabular}


Table 3: Environmental variables associated with fish distribution, classified by system attribute and observational scale. Synthesis is based on 658 papers dealing with management of fish in rivers, including 27 papers that acknowledge and compare across scales (modified from Durance et al., 2006).

\begin{tabular}{llll}
\hline $\begin{array}{l}\text { System } \\
\text { attribute }\end{array}$ & Catchment & $\begin{array}{c}\text { Scale of environmental variable } \\
\text { Segment/reach }\end{array}$ & Habitat/riparian \\
\hline $\begin{array}{l}\text { Temperature } \\
\text { variability }\end{array}$ & $\begin{array}{l}\text { Climate, elevation, } \\
\text { drainage area }\end{array}$ & Channel morphology & $\begin{array}{l}\text { Vertical hydraulic ex- } \\
\text { changes }\end{array}$ \\
\hline $\begin{array}{l}\text { Hydrologic } \\
\text { regime }\end{array}$ & $\begin{array}{l}\text { Climate, geology and } \\
\text { drainage area }\end{array}$ & $\begin{array}{l}\text { Channel morphol- } \\
\text { ogy/complexity, reach } \\
\text { size, reach elevation }\end{array}$ & $\begin{array}{l}\text { Habitat morphome- } \\
\text { try/complexity and } \\
\text { depth }\end{array}$ \\
\hline $\begin{array}{l}\text { Spatial configu- } \\
\text { ration }\end{array}$ & $\begin{array}{l}\text { Connectivity with other } \\
\text { waters }\end{array}$ & $\begin{array}{l}\text { Lateral/catchment con- } \\
\text { nectivity, dams }\end{array}$ & $\begin{array}{l}\text { Connection with main } \\
\text { stream, log weirs }\end{array}$ \\
\hline Chemistry & Water chemistry & Water chemistry & Water chemistry \\
\hline Biotic features & $\begin{array}{l}\text { Catchment vegetation, } \\
\text { biome, land use }\end{array}$ & Cover, land use & $\begin{array}{l}\text { Food resources, preda- } \\
\text { tor/competition, ripar- } \\
\text { ian vegetation/land use }\end{array}$ \\
\hline History & Past biome, climates, & $\begin{array}{l}\text { Past land uses, temper- } \\
\text { atures, dams }\end{array}$ & Dams \\
\hline
\end{tabular}




\section{Challenges to landscape riverine research}

\subsection{Has new research utilized the strengths of new technologies or are we doing the same old stuff with more expensive data?}

The vast quantity of readily available spatial data sets over large areas, new methods for collecting spatial data with smaller and smaller grain sizes, and the improved computing power of spatial analytic software suggest that whole new approaches to landscape riverine ecology are now possible. By providing synoptic views of streams and their catchments at multiple resolutions, and by providing the spatial analytical framework to exploit the power of digital maps, these new technological tools provide the capability to examine interrelationships between streams and their catchments in ways that were either extremely limited or impossible in the past. Our first question is whether new research is truly harnessing the power of these new resources or whether we are simply doing the same old things with new data that are more resource-intensive to collect.

\section{Mapping the water itself}

Habitat parameters particularly amenable to remote sensing include water temperature and stream depth; substrate type can also be collected under certain conditions. Analyses that apply these new types of data have made considerable progress in our understanding of how streams and landscapes interact. The work of Torgersen et al. (1999, 2001), for example, demonstrated how high resolution airborne FLIR systems could be used to assess the spatial distribution of thermal habitats relevant to stream fishes of the Pacific Northwest, USA. Techniques developed by Fonstad and Marcus (2005) link spectral reflectance, stream discharge measured at local gages, and equations describing stream resistance into predictive models of depth termed "hydraulically assisted bathymetry". These techniques and similar efforts by Bjerklie et al. (2003, 2005) hold promise for mapping stream depth over entire stream networks without the need for field data. Additionally, retrospective studies using archival photography have examined temporal trends in stream depth due to land use changes (Fonstad and Marcus, 2005). In a separate study, Lorang et al. (2005) linked fieldderived estimates of water depth, flow velocity, shear stress, and stream power to multispectral imagery to spatially model geomorphic processes in gravel-bed rivers. While these techniques are promising, Legleiter and Roberts (2005) found that channel morphology could affect the accuracy of image-derived depth estimates.

\section{Employing new instream habitat data}

Recent years have seen remarkable advances in application of high resolution remote sensing to the study of stream physical habitat structure. Newly available systems enable pixel resolutions of 1-meter or better, providing the fine spatial resolution needed to detect and map instream features of small rivers and streams. Wright et al. (2000) used 1-meter resolution multispectral (e.g., 4 wavelength band) digital imagery to map stream morphological units (eddies, glides, riffles, scour pools, etc.) of 3rd and 4th order streams with moderate to high levels of success. Then, in a series of pioneering studies (Legleiter et al., 2004; Legleiter, 2003; Marcus et al., 2003), high spatial resolution hyperspectral imagery was shown to be effective at mapping instream habitat features including woody debris, depth, and substrate. The authors tested spectral band ratios and classification methods for extracting stream habitat information from spectral imagery (Legleiter, 2003; Marcus et al., 2003) and developed the basis for physical models relating spectral reflectance to instream features (Legleiter et al., 2004). Their results demonstrate the feasibility of these technologies for mapping small streams, although higher accuracies were possible in larger streams (Marcus et al., 2003). Leckie et al. (2005) exploited high spatial resolution $(80 \mathrm{~cm})$ multispectral data for mapping instream habitat and were able to reliably map substrate, woody debris, and

Living Reviews in Landscape Research

http://www. livingreviews.org/lrlr-2010-1 
depth classes. Feurer et al. (2008) reviewed progress in mapping underwater topography using radiometric models and through-water photogrammetry. McKean et al. (2009a,b, 2008); Madriñán (2008); Kinzel et al. (2007) have had success mapping stream and riparian habitat using LiDAR.

In addition to physical habitat features, direct sensing of submerged aquatic vegetation and algae are now possible by combining high resolution imagery and GIS modeling. Lehmann and Lachavanne (1997) provided a comprehensive review of the topic, although at the time most applications were limited to larger rivers or estuaries, primarily because of a lack of data at the appropriate scale. The interaction of light with the water column introduces spectral classification and interpretation issues unique to aquatic environments, but the theoretical basis for remote sensing of aquatic vegetation has been established (Silva et al., 2008). Although applications to small streams are still rare, the potential of hyperspectral imagery for mapping aquatic vegetation over entire catchments is evident (Govender et al., 2007; Nelson et al., 2006).

\section{Impediments and opportunities to harnessing new technologies}

Most aquatic mapping applications to date have used passive optical remote sensing to relate stream properties to spectral reflectance patterns in imagery. Interpreting and extracting information from these data requires a high level of operator skill and data acquisition over large areas is expensive. Marcus and Fonstad (2007) reviewed applications to date and discussed the potential and limitations of this technology for advancing river science. While they predicted that future developments of optical remote sensing would create continuous meter-scale maps of stream habitats across entire river systems, they rightly discussed obstacles and issues that must be addressed to insure future advancement. These problems include difficulty mapping areas with steep terrain (valleys and canyons), differential illumination of stream habitats because of shading and surface turbulence, the need for clear water conditions for assessing instream habitat features and vegetation, timing constraints in image acquisition because of satellite overpass or weather conditions, the cost of acquiring repeat imagery, difficulties assessing mapping accuracy of stream features, and ethical issues related to revealing habitat locations that could be easily exploited by anglers (Marcus and Fonstad, 2007). As well, promising new data are often available for ecological research only in limited pilot areas and there is a disproportionate amount of data for large versus small rivers. Some parameters are still limited to clear waters or surface waters (e.g., temperature). It often remains prohibitively costly to assess dynamic stream habitat environments from repeated flights of static airborne imagery. The increased availability of remote sensing data, as well as field data collected from different large-scale monitoring programs, creates substantial data aggregation problems (Roper et al., 2010; Independent Multidisciplinary Science Team, 2009) and the costs of obtaining, storing, manipulating, and interpreting such imagery are nontrivial.

In spite of these limitations, great potential exists for further refinement of optical remote sensing techniques, especially when combined with other sensing technologies to assess the complete aquatic environment (Marcus and Fonstad, 2007; Leckie et al., 2005). While just beginning, the application of high resolution active remote sensing methods such as LiDAR for mapping stream morphology and habitat features (McKean et al., 2009a,b, 2008; Feurer et al., 2008; Kinzel et al., 2007) holds promise for precise mapping of channel morphology and water surface elevation. When combined with optical methods (Hall et al., 2009) and thermal imaging, the possibility exists for mapping multiple stream parameters over large regions for a nearly complete assessment of fish habitats. Host et al. (2005), for example, published a complex spatial analysis that provided an efficient method for the identification of reference areas along the Great Lakes coast, USA.

All relevant technological advances will not be solely in the collection and processing of spatial data. In ichthyological and fisheries sciences, researchers have recently developed a technique to reconstruct migration history of individual fishes based on chemical analysis of bony tissue, otoliths. Otolith microchemistry, especially when combined with landscape-scale data, could provide new 
avenues to study fish migration across large areas and to identify effects of landscape disturbances such as dams on riverine fishes (e.g., Clarke et al., 2007; Hogan and Walbridge, 2007).

\subsection{Have we incorporated key concepts from landscape ecology to im- prove our understanding of how landscapes affect rivers?}

The field of landscape ecology has focused on the relationships between pattern and process as well as on planning for patterns of human land use (Forman and Godron, 1986). Within landscape ecology, rivers have traditionally been characterized as landscape elements (Wiens, 2002) rather than as the target of large-scale processes or as the research focus. There have been many calls to apply principles of landscape ecology in river ecology (e.g., Wang et al., 2006a; Wiens, 2002) or to incorporate the dynamic elements of rivers into landscape thinking. Below, we briefly describe five elemental concepts from landscape ecology and how they have been applied to improve our understanding of how landscapes alter rivers.

\section{Relationships between Patterns and Processes}

A fundamental underpinning of the field of landscape ecology is the study of relationships between patterns and processes, usually over broad spatio-temporal scales (Turner, 2005). Specifically, landscape ecologists seek to understand how ecosystem processes act to form patterns on the landscape, and of equal interest, how landscape patterns can influence ecological processes. Aquatic ecologists have made great strides toward understanding ecosystems by including this important concept (Fausch et al., 2002; Ward et al., 2002; Townsend, 1996). For example, researchers have investigated how ecosystem processes such as climate, hydrology, and geomorphology influence stream characteristics (e.g., Benda et al., 2004; Swanson et al., 1988) and fish distribution patterns (e.g., Pess et al., 2002). More prevalent are examples of the possible effect of upland landscape composition on the functioning of instream processes. Researchers have related distributions of natural features in the surrounding landscape, such as topography and soils (e.g., Richards et al., 1996), and human land use (e.g., Independent Multidisciplinary Science Team, 2010; Brown et al., 2005; Kershner et al., 2004; Van Sickle et al., 2004; Snyder et al., 2003; Paul and Meyer, 2001; Roth et al., 1996) to instream biodiversity and viability of fishes.

To date, most landscape-scale research on lotic systems has attempted to evaluate relationships between pattern and process by quantifying the effect of the composition of surrounding upland landscapes (e.g., 40\% of a watershed is in low-density residential land use) on some instream feature (e.g., fish abundance Paulsen and Fisher, 2001). Inclusion of metrics of landscape structure in both upland landscapes (e.g., connectivity of non-impervious areas or average patch size of high quality riparian forest; Gergel et al., 2002) and within aquatic landscapes (e.g., longitudinal connectivity of suitable habitat patches; Isaak et al., 2007; Torgersen et al., 2006; Benda et al., 2004; Wiens, 2002 ) is an opportunity to clarify our understanding of the interaction between terrestrial and aquatic systems.

\section{Scale}

Integral to both landscape ecology and aquatic ecology is recognition that relationships between organisms and their habitats depend on the spatio-temporal scales at which they are observed (e.g., Talley, 2007; Durance et al., 2006) (Figure 1). Scale is clearly important in identifying and analyzing spatial pattern (Feist et al., 2010; Wu, 2004; Wu et al., 2002; Turner et al., 1989) and has garnered much attention over the past 20 years or so (Levin, 1992; Wiens, 1989). Schneider (2001) dedicated a special section to addressing the many ways that scale can be defined and Jenerette and $\mathrm{Wu}$ (2000) wrote an entire essay on the multiple definitions of scale. The emphasis of landscape ecology on scale has led riverine landscape research to use multi-scale studies in order

Living Reviews in Landscape Research

http://www. livingreviews . org/lrlr-2010-1 
to gain a better understanding of processes acting in a stream network (Lowe et al., 2006; Leclerc and DesGranges, 2005; Fausch et al., 2002; Lammert and Allan, 1999; see Table 3 in Johnson and Host, 2010, for further examples). Because of the strong migratory behaviour of many fishes, they are ideal study subjects for testing hypotheses about scale (Schmutz and Jungwirth, 2001). Processes affecting fish assemblages range from global to local scales (Durance et al., 2006; Tonn, 1990).

Existing cross-scale studies have provided contradictory results giving either more weight to local (Walters et al., 2003) or catchment factors (Mugodo et al., 2006; Marsh-Matthews and Matthews, 2000). Studies that examine instream response to land use at multiple scales report, unsurprisingly, mixed influence (Feist et al., 2010; Stewart, 2001; Fitzpatrick et al., 2001; Richards et al., 1996; Roth et al., 1996; Johnson and Host, 2010; see Table 3 in Johnson and Host, 2010, for further examples). For example, near-stream connected imperviousness had a stronger influence on fish assemblages than did comparable amounts of impervious surface located farther from the stream, apparently owing to increased severity and frequency of high-flow events and lowered baseflow (Wang et al., 2001); Yet, catchment-scale influence may be greatest when the primary mechanism is flow instability, nutrients, or some other factor related to the entire landscape (Allan, 2004a). Wang et al. (2006a) found that fish assemblages were mainly influenced by local factors in undisturbed catchments whereas the relevance of catchment scale factors increased with increasing landscape disturbance.

Opportunities for advancing the study of scale in landscape riverine research are emerging from the advances in technology described in Section 2.3, which are providing fine-grain data over large extents even on small rivers. To explicitly measure the influence of scaling on fish populations, we must hold the grain constant as we vary the extent, and vice-versa. There are many good examples in the literature of varying the analysis extent while holding the grain constant (e.g., Moerke and Lamberti, 2006; Creque et al., 2005; Santoul et al., 2005; Feist et al., 2003). It is unusual to find riverine examples in which researchers varied the grain while holding the extent constant. There are examples from theoretical ecology, but these are usually in small systems under controlled conditions.

\section{Connectivity}

Landscape ecologists define connectivity as the degree to which the landscape facilitates or impedes the ability of organisms to move among resource patches (Taylor et al., 1993). Hitt and Angermeier (2008b, 2006) found that failure to consider spatial connectivity may bias measures of biotic integrity. However, classic connectivity metrics used in two-dimensional ecosystems such as terrestrial or oceanic landscapes (Calabrese and Fagan, 2004) are not easily applied in stream networks for several reasons. First, quantifying connectivity in stream networks is more challenging than quantifying connections in two-dimensional habitats (Fagan, 2002). Second, resource patches in temporally dynamic aquatic systems typically experience a high degree of patch turnover (Gresswell et al., 2006). Third, organisms must contend with the force of current velocity, which may affect locomotive abilities and alter directional movement among habitats (e.g., Olden, 2007; Gresswell et al., 2006). Fourth, the apparent existence of different riverine zones that appear to support different fish assemblages suggests that fish species pools are filtered by various longitudinally varying river characteristics such that some species are limited to specific areas (Ibañez et al., 2009; McGarvey and Hughes, 2008; Vannote et al., 1980; Hawkes, 1975; Huet, 1949; Fritsch, 1872). Some recent progress has been made towards quantitatively measuring and studying connectivity in streams (Cote et al., 2009; Hitt and Angermeier, 2008a; Hughes, 2007; Isaak et al., 2007; Ganio et al., 2005; Fagan et al., 2002) but many opportunities to refine and explore the topic exist. 


\section{Landscape fragmentation by dams}

Barriers and dams are a particularly pressing ecological problem (Graf, 1999). They fragment aquatic systems both by impeding fish migrations and by disconnecting physical processes such as the transport of wood, water, and sediment. In Europe, for example, dams and water pollution in the Rhine and Danube Rivers have reduced the native fish fauna, particularly salmonids and sturgeons (Bacalbasa-Dobrovici, 1989; Lelek, 1989). Likewise, dams have eliminated several diadromous fish species from the Seine River, France (Oberdorff and Hughes, 1992). And, a vast network of dams and flow alterations on the Colorado River and Rio Grande, USA, have resulted in deteriorated water quality, flows frequently failing to reach the sea, and replacement of endemic fish faunas by invasive non-indigenous species (Hughes et al., 2005b). Among major USA rivers draining to the Pacific Ocean, those with mainstem dams without fish passage or with inadequate fish passage (e.g., Snake, Columbia, Klamath, Sacramento-San Joaquin Rivers) have all experienced substantial flow and channel alterations, water pollution, species extirpations, and reaches dominated by non-indigenous species (Brown et al., 2005; Hughes et al., 2005b; Ebel et al., 1989). Even small low-head dams can eliminate native species and alter the distributions of non-indigenous species (LaVigne et al., 2008a; Holden et al., 2005; Meffe, 1984). The fish species most affected by instream anthropogenic barriers are species with a limited range of habitat types and migratory species. Understanding the magnitude of fragmentation caused by dams requires investigations over large extents.

One area where riverine landscape research has made strong progress is in quantifying the impacts of landscape fragmentation by dams on aquatic systems, and, in particular, on fish assemblages. Fukushima et al. (2007) were able to quantify impacts of watershed fragmentation on fish assemblages through use of spatially explicit models applied to the occurrence data of multiple freshwater fish species inhabiting Hokkaido Island, Japan (ca. 80,000 km²). Sheer and Steel (2006) quantified a relationship between the amount and distribution of lost aquatic habitat as a result of dams or barriers and salmon population performance. Letcher et al. (2007) found that habitat fragmentation by barriers increased the likelihood of local and system-wide extinction. We did not identify research examples in which other human impacts, such as pollution, altered thermal regimes, or flow alterations, were explicitly considered through the lens of landscape fragmentation or reduced connectivity between habitats.

There are global inequities in our understanding of the impacts of river fragmentation on fish assemblages and communities. The scarcity of quantitative data in developing countries presents a tremendous challenge to assessing effects of human disturbances on riverine ecosystems. The lack of scientific data may be contributing to aggressive human development in these same regions. For example, the Mekong River, the 11th-longest river in the world, is being fragmented by a series of large dams (Baran et al., 2007). Dam construction within the Mekong watershed is on the rise with increasing demand for hydroelectricity. The Yangtze River, the third longest river in the world, now has the world's largest dam, the Three-Gorges Dam, fragmenting an area of about $58,000 \mathrm{~km}^{2}$ (Xie, 2003). These enormous hydrologic alterations are predicted to significantly reduce both terrestrial (Wu et al., 2003) and aquatic (Park et al., 2003; Xie, 2003) biodiversity, eventually diminishing fisheries resources and food security (Baran et al., 2007). A "geowiki" is being developed by Mark Mulligan at King's College in London to help coordinate data-sharing and improve spatial coverage of data on dams (http://www.kcl.ac.uk/schools/sspp/geography/ research/emm/geodata/geowikis.html). The database combines the visualization capabilities of Google Earth with the power of multiple Internet users to develop a comprehensive global database of dams.

Living Reviews in Landscape Research

http://www. livingreviews . org/lrlr-2010-1 


\section{Humans are integral to ecosystems}

Economic and population growth dramatically influence the functioning of ecosystems. For example, economic prosperity has been associated with declines in biodiversity worldwide (Clausen and York, 2008; Leprieur et al., 2008b; Naidoo and Adamowicz, 2001), and may be especially problematic for freshwater fishes (Miller Reed and Czech, 2005; Rose, 2005). Urbanization has significant impacts on freshwater ecosystems. The consistent hydrological effect of urbanization, including flashy flows (more frequent, short-lived, more intense), is a result of the increased amount of impervious surfaces in urban streams (e.g., Booth et al., 2004). Researchers have also been able to detect more diffuse effects of urbanization and land use (e.g., Randhir and Ekness, 2009; Bilby and Mollot, 2008; Alberti et al., 2007; Walsh et al., 2005; Kershner et al., 2004; Paulsen and Fisher, 2001; Paul and Meyer, 2001; Roth et al., 1996). Human threats to imperiled fish populations also include the spread of non-native species (Leprieur et al., 2008a) and global climate change (Crozier et al., 2008; Rieman et al., 2007; Flebbe et al., 2006). A concept in landscape ecology that is becoming more evident in recent years is the notion that humans should be considered as part of the ecosystem being managed, rather than as an outside factor exerting negative impacts on natural systems (Otte et al., 2007; Wu and Hobbs, 2002). Few riverine studies or approaches have incorporated this mindset.

\subsection{Have we been able to use landscape analyses to address management and policy needs?}

Results of landscape analyses have significant implications for management of streams and catchments as well as for developing informed policies on land management. The genesis of this field lies in great part with policy directives, the increasing need for catchment-scale management, and wide-ranging environmental problems as discussed in Section 2. Therefore, landscape analyses are often intended to have on-the-ground impacts. However, evaluating the degree to which landscape analyses have actually been used for making management decisions is difficult because many peer-reviewed publications define the possible or intended application rather than the actual application. Allan (2004a) noted that there are limitations in the degree to which these types of analyses can inform management prescriptions and fisheries management. He and others have indicated the need for a more experimental approach in which systematic variations in land use are considered. In this section, we identify the most common potential applications of landscape analyses for riverine management and those papers that explicitly focus on these applications.

\section{Conservation of species, populations, and biodiversity}

Because landscape ecology has traditionally involved evaluation of spatial patterns of land use and species distributions, it has followed naturally that newfound knowledge was applied to ecosystem management such as the creation of conservation reserve networks (Thieme et al., 2007; Margules and Pressey, 2000). Landscape-scale riverine analyses often apply high spatial resolution satellite and aerial imagery to identify conservation and restoration needs of large and complex aquatic ecosystems. The Missouri Aquatic GAP Project, for example, used landscape-scale data to identify types of aquatic habitats not adequately represented within the existing conservation network (Sowa et al., 2007). Randhir and Tsvetkova (2009) used landscape-scale data to explore conservation implications of relationships between water conservation and management strategies. And, Ballinger and Mac Nally (2006) used a landscape perspective to explore the impacts of spatial and temporal flooding variability on wildlife habitats in the Murray-Darling Basin, Australia. Statistical models were built and tested using species occurrence data for multiple fish species in the Iberian Peninsula (Filipe et al., 2004). These models used landscape characteristics to quantify the multi-species conservation value of particular river reaches and, eventually, to select a series 
of reserve reaches. Ekness and Randhir (2007) identified spatial criteria for watershed-scale policy development. They concluded that basing conservation networks on stream order, riparian condition, and land use could lead to increased riparian areas, protection of headwaters, and minimized disturbance in headwater areas. However Li et al. (1996) and Dunham et al. (2008) recommended protection of mainstem reaches and entire channel networks, and Osborne and Wiley (1992) and Hitt and Angermeier (2008b) have reported on the importance of confluences to fish species occurrences in tributaries.

Species-based examples of applying landscape-scale data to conservation management include restoration of the Middle Rio Grande in New Mexico, USA for the endangered silvery minnow (Cowley, 2006), estimation of potential steelhead habitat above barriers in the Willamette River basin, Oregon, USA (Steel et al., 2004), or probability of occurrence of two diadromous fish species in New Zealand (Eikaas et al., 2005). Landscape condition has also been used to estimate the frequency and severity of ecosystem threats, such as the frequency of human-induced stressors, to provide a more informed basis for conservation planning (Mattson and Angermeier, 2007; Kracker, 2006). An example of the use of large-scale analyses to identify specific landscape stressors and the impact of those stressors on fish assemblages is Scott (2006), who quantified the impacts of urbanization on endemic versus broad-ranging fishes.

\section{Management of riparian areas and catchments}

One of the most obvious and far-reaching impacts of landscape analyses for land use management has been the promotion of the riparian zone as a critical transition area between streams and their catchments. In rehabilitating lateral connectivity, studies have emphasized establishing or enlarging riparian wooded buffer zones (Miltner et al., 2004; Freeman et al., 2003; Snyder et al., 2003; Wichert and Rapport, 1998). Riparian management is particularly attractive because of the riparian zone's immediate influence on stream condition and because it promises benefits that are highly disproportionate to the land area required (Allan, 2004a). The landscape perspective can improve management of riparian lands by identifying the best strategies for particular areas. For example, the landscape perspective enabled fine-tuning of forest buffer restoration priorities in agricultural areas of Maryland, USA by quantifying those underlying geologies for which forested buffers had the greatest impact on indices of biotic integrity (Barker et al., 2006). FEMAT (1993) also took a landscape approach in its recommendation of a riparian buffer equivalent to 2 site-potential tree heights along fish bearing streams, because the size of trees varies by ecoregion. Multi-scale analyses have been used to demonstrate that riparian management shows greater effectiveness in protecting streams from the negative impacts of land use at the local or reach scale than at the catchment scale. Intensive land use at the scale of entire catchments may have impacts too great for a riparian zone to moderate (Wang et al., 2006b; Allan, 2004a; Snyder et al., 2003; Morley and Karr, 2002; Nerbonne and Vondracek, 2001; Roth et al., 1996).

Use of landscape analyses to improve land management across entire catchments has been more challenging. Reversal of land use to a less-developed state over vast extents is usually infeasible; however, improvement of stream conditions can be accomplished by promoting best management practices (BMPs) and improvements in landscape management, e.g., reduced fertilizer applications in the catchment (Wang et al., 2006c) or conservation tillage (Yoder et al., 2005). However, where native fish species have been extirpated, improvements in land use alone may not be enough to restore species distributions to their historic states (Wang et al., 2006c).

\section{Bio-assessment}

The landscape perspective has improved fish-based bio-assessments through validation of biotic indices and identification of appropriate sampling scales. Correlations between indices of biotic

Living Reviews in Landscape Research

http://www. livingreviews.org/lrlr-2010-1 
integrity and landscape conditions have validated expected relationships between degraded landscapes and stream condition (e.g., Carlisle et al., 2008; Pinto et al., 2006; Bramblett et al., 2005; Dauwalter and Jackson, 2004; Joy and Death, 2004). However linking instream biological responses to landscape (land use, economic growth, population growth; Schleiger, 2000; Leprieur et al., 2008a) and riverscape (dams, diversions; Stanford and Ward, 2001; Ward and Stanford, 1995) stressors requires different analytical approaches than the site-specific studies that comprise most biological assessments. For example, Hawkins et al. (2000) found that while landscape data can explain more variation in aquatic biota than what might be expected by chance alone, the amount of variation explained is not large, and thus will have limited value in making reach scale predictions. Herlihy et al. (2006) reported that landscape classifications accounted for approximately half the variability in fish assemblage clusters of the conterminous USA; however Pinto et al. (2009) reported that ecoregion and fish species clusters had similar classification strengths at a river basin scale.

Many analyses correlating land use with indices of biotic integrity have compared models at varying spatial scales such as riparian buffer scales and catchment scales (e.g., Barker et al., 2006; Van Sickle et al., 2004). Such analyses have begun to identify the specific scales at which land use drives various types of biotic indices. Fish-based and macrophyte-based biological indices are often more closely correlated with ecological quality at the river basin scale whereas indices based on macroinvertebrates and benthic diatoms are more closely correlated with environmental metrics at the reach and stream scale (Springe et al., 2006). Brazner et al. (2007) and Allen et al. (1999) reported similar differences among biological indicators of disturbance in northeastern USA lakes and Great Lakes wetlands, respectively. In addition, recent focus on stream network topology has demonstrated the importance of considering position in the stream network and dispersal rates when using bioindicators to assess fish assemblage responses to the environment (Hitt and Angermeier, 2008b). The landscape perspective inherent in these studies has led to improved use of biological indicators of stream health; however, the lack of specific and tested mechanistic relationships between remote landscape conditions and instream biological response continues to plague on-the-ground applications and to limit the applicability of results beyond the study basins.

\section{Prioritization of rehabilitation activities}

Another common application of the landscape perspective is in determining where, within a catchment, rehabilitation activities should be undertaken. Some approaches have used riparian condition to identify those sub-basins most likely to respond to rehabilitation activities (e.g., Fullerton et al., 2006) others have identified locations within basins that are most likely to increase aquatic connectivity or provide cumulative positive impacts (Jansson et al., 2007). Landscape characteristics have been used to estimate the quantity of lost habitat behind migration barriers (Sheer and Steel, 2006) and to predict the quality of habitat where fish currently do not exist, such as behind migration barriers, and prioritize barrier removal projects (Steel et al., 2004).

A large-scale perspective is necessary for rehabilitation prioritization for three reasons. First, the watershed is the unit of observation. Abiotic conditions and biological assemblages within a watershed are interdependent and cannot be effectively examined in isolation. Second, funding is often distributed for political equity and/or by watershed and so decisions about what restoration actions to fund must prioritize across all possible actions within a political jurisdiction or watershed. And, third, rehabilitation actions are often aimed at reducing impacts associated with large scale degrading processes such as wood, sediment, nutrient, and water delivery (Lake et al., 2007). Understanding these large-scale habitat-forming processes (Beechie and Bolton, 1999) across entire catchments aids us in identifying and prioritizing aquatic rehabilitation activities at the appropriate temporal and spatial scale. Weber et al. (2007) credit the failure of many rehabilitation and restoration projects to a failure to consider degrading factors over large enough spatio-temporal scales. 
Rehabilitation of entire catchments would be ideal but is rarely practical. However, the condition of the catchment can still inform decisions about which types of rehabilitation to initiate first. As pressures increase in the catchment, the importance of local factors may decline. In catchments experiencing intensive pressure from human development, instream projects should be initiated only after substantial progress in removing major causative factors is made (Schmutz et al., 2007; Booth et al., 2004). Large-scale analyses suggest that rehabilitation prioritization in degraded catchments should be geared toward rehabilitating upslope processes first (e.g., rehabilitating the sediment, wood and water flow regimes; Bohn and Kershner, 2008) or should emphasize rehabilitation of upslope processes in combination with local rehabilitation measures (Schmutz et al., 2007; Wang et al., 2006b; Booth et al., 2004; Soulsby et al., 2001). In relatively undisturbed catchments, local instream habitat and riparian improvement will be most effective (Wang et al., 2006b).

Many kinds of decision tools are now developed to set priorities in catchment-scale rehabilitation planning (e.g., Roni et al., 2008; Steel et al., 2008; Schmutz et al., 2007; Fullerton et al., 2006; Shriver and Randhir, 2006; Reynolds and Peets, 2001). Landscape-scale analyses can inform predictions of future conditions, often through scenario-based tools that integrate landscape evaluations and restoration or rehabilitation planning (e.g., Randhir and Hawes, 2009; Fullerton et al., 2009; Steel et al., 2008; Reynolds and Hessburg, 2005). Decision support frameworks such as the Ecosystem Management Decision Support (EMDS) have been used in salmon recovery planning efforts in the Pacific Northwest USA (Reynolds and Hessburg, 2005). Rieman et al. (2001) evaluated the effect of a variety of land management schemes on salmonid viability, and Burnett et al. (2007) evaluated how potential habitat available to salmonids is distributed among different land use classes. Using aerial photos, Freeman et al. (2003) not only evaluated possible future states in a floodplain, but also evaluated how land use has changed through time using aerial photos. The landscape perspective enables scenario planning to consider far-ranging impacts of particular actions and to provide spatially explicit predictions of trade-offs in future condition that would result from alternative action schemes. The maps of potential future conditions that often result from landscape-based scenarios can be particularly helpful in soliciting citizen input and engaging local landowners (e.g., Baker et al., 2004; Hulse et al., 2004).

\section{Climate change and scenario-based planning}

Landscape-scale analyses will be essential in predicting impacts of climate change (e.g., Battin et al., 2007; Rieman et al., 2007; Flebbe et al., 2006) and in identifying management alternatives that are robust to the suite of likely climate change scenarios. Matulla et al. (2007) modeled the impact of IPCC (Intergovernmental Panel on Climate Change) emission scenarios on the fish assemblages of the Mur River, Austria. They used downscaled temperature and precipitation predictions to model instream river temperatures over the entire basin in order to identify native species at risk of extirpation and non-native species with increased potential for invasion. Rieman et al. (2007) examined potential effects of climate change on bull trout (Salvelinus confluentus) over the entire interior Columbia Basin. Working over such large extents, they were able to identify populations of bull trout that faced particularly high potential habitat losses.

In a recently published report of the European Parliament on climate change-induced water stress, land use management was identified as a key issue in adaptation strategies (Anderson et al., 2008). Land use measures that may support adaptation to climate change include, for instance, forestation, conservation agriculture, floodplain rehabilitation, the conversion or rehabilitation of natural land cover, and wetlands rehabilitation. In the Netherlands, projects are being implemented that limit development along rivers to reduce vulnerability to climate change-induced increases in flood risk. The Room for the River Program recognizes the need to widen the river floodplain, rather than increase the height of the dikes (http://www.ruimtevoorderivier.nl/).

Living Reviews in Landscape Research

http://www. livingreviews . org/lrlr-2010-1 


\section{Monitoring}

Large-scale riverine monitoring programs have been driven by the needs of managers and scientists to understand how natural conditions and human impacts vary across watersheds and landscapes (USEPA, 2009; Paulsen et al., 2008; Hughes et al., 2006a; Pont et al., 2006; Yates and Bailey, 2006; Stoddard et al., 2005). Spatially extensive perspectives and landscape analyses have been essential in designing monitoring programs that capture watershed-scale habitat conditions and track performance of entire populations. For example, the USEPA's Environmental Monitoring and Assessment Program (EMAP) began in 1989 and now samples roughly 900 probabilistically selected aquatic sites each year using a rotating panel design (i.e., lakes in 2007, rivers in 2008, streams in 2009, coastal waters in 2010, wetlands in 2011, lakes in 2012, etc.) (Shapiro et al., 2008; Hughes et al., 2000). Biological data, environmental data, and watershed parameters are measured at each site. The probabilistic design and nationally consistent methods allow rigorous statistical inference to all water bodies of each type. Based on the 2005 national wadeable stream survey, Paulsen et al. (2008) reported that $42 \%$ of all wadeable stream length in the conterminous USA was in poor condition, and the major stressors were nutrients and excess fine sediments. USEPA (2009) reported that $22 \%$ of USA lakes were in poor biological condition based on changes in their diatom assemblages, $36 \%$ had poor riparian vegetation cover, and $20 \%$ were considered to have poor levels of nutrients. A key component in these assessments was the use of large-scale monitoring data.

In 1990, the USGS began its National Water Quality Assessment Program (NAWQA), which focused monitoring and research on 42 study units representing different hydrologic regions and pressures (agriculture, urbanization). The NAWQA program rotates its intensive sampling on 14 of the study units every 3-4 years and proposes to develop models to predict conditions in unmonitored areas (Gilliom et al., 2001). In a 5-year NAWQA study of 9 urban areas, Brown et al. (2009) found that the effects of urbanization on fish assemblages differed among those areas. They reported that urbanization affected stream habitats and fish assemblages differently because of natural landscape differences as well as the legacy effects of agriculture.

A major monitoring program (Sustainable Rivers Audit, SRA) for the Murray-Darling Basin in Australia was initiated in 2000, using subbasins as reporting units and systematically rotating annual sampling of 180-341 sites among those basins every 2-3 years (Davies et al., 2006). The SRA stratifies sampling and data analyses by altitudinal zones (lowlands, slopes, uplands, montane) and sites are chosen randomly within each zone to ensure that they are representative.

Large-scale analyses are often applied to monitor the cumulative effectiveness of multiple instream rehabilitation (restoration) projects. For several decades a wide variety of agencies within the United States have implemented stream rehabilitation (restoration) projects, but rarely has the effectiveness of those projects been monitored (Alexander and Allan, 2006; Palmer and Bernhardt, 2006; Thompson, 2006; Bernhardt et al., 2005; Roni et al., 2002).

The situation is somewhat better in central Europe where $58 \%$ of 50 projects were monitored (Kail et al., 2007). Statistically and ecologically rigorous monitoring of the effectiveness of individual rehabilitation projects is a substantial undertaking and scaling the inference up to evaluate effectiveness at larger scales has rarely been done effectively (Thompson, 2006; Ioannidis, 2005). A key issue in all monitoring programs is the question of sufficient and standardized sampling effort to ensure that site-scale noise or variance among field crews is low relative to the variance or signal from the population of sites being assessed. Standard sampling methods facilitate data compilation and comparison (Bonar et al., 2009; Independent Multidisciplinary Science Team, 2009). Sufficient site extents reduce the local variability that confounds comparison with landscape-scale variables (Flotemersch et al., 2010; Hughes et al., 2008). And high signal-noise ratios increase the potential R-squared values of regression or other statistical analyses when relating assemblage response variables to predictor variables (Stoddard et al., 2008). The 2009 IMST report found that lack 
of comparability in survey designs, indicators, and sampling methods hindered data aggregation despite millions of dollars dedicated to disparate research projects in the same area.

\section{Opportunities in landscape-scale riverine research}

\subsection{Moving toward mechanism}

Mechanisms linking landform, land use, and climate to instream conditions and fish responses are often hypothesized but we have few formal ways of testing mechanisms that operate over such vast areas. The greatest challenges and, therefore, greatest potential opportunities in the field, clearly lie in our ability to identify and test specific mechanisms. Johnson and Gage (1997) wrote that relationships between the landscape and the stream were not yet well enough defined or quantified as to permit specific predictions of instream responses. This lack of hypotheses has proven a major roadblock to uncovering mechanisms about how streams interact with their surrounding landscapes.

The vast majority of analyses using these data have focused on identifying correlations between landscape conditions and instream conditions, such as fish assemblages, indexes of biological integrity, or water quality parameters. For example, Carlisle et al. (2008) correlated biological indices based on fish with urban and agricultural land uses and Pinto et al. (2006) found a negative correlation between percent urban area and fish assemblages. Creque et al. (2005) linked landscape-scale variables such as mean July temperature with spatial variation in the density of sport fish in Michigan, USA. Often, as Creque et al. (2005) did, these analyses compare the relative magnitude of landscape-scale variables versus site-scale variables such as depth, pool distribution, or channel gradient or they compare relationships across similar variables measured at multiple scales (e.g., Feist et al., 2010, 2003; see Table 1 in Durance et al., 2006, for further examples). Many additional examples of correlative analyses linking landscapes and aquatic systems can be found. Those published before 2004 are summarized in Allan (2004a) (see Table 2).

Correlative studies run the risk of assuming causality between things that are merely coincident or that share some common yet unmeasured driver. Allan (2004a) commented that correlative analyses are often plagued by (1) covariation between anthropogenic influences and natural landscape gradients; (2) multiple scale-dependent mechanisms; (3) non-linear relationships; and (4) difficulties in untangling impacts of current versus past conditions. GIS software combined with multi-layer remotely sensed data can generate, literally, hundreds of potential predictor variables for any instream response of interest. As these data are dredged, spurious relationships are bound to arise. Results of the MIRR Project in Austria (Schmutz et al., 2007) show that "uncontrolled observations" of the hydromorphological status of streams have led to numerous uncontrolled and cross-correlated variables. In another example, Dauwalter and Jackson (2004) identified counter intuitive relationships that they explained as the result of random observations over limited ranges of land use and water-quality variables.

One sign of our over-reliance on correlative relationships is our inability to make predictions in new areas. Meta-analyses of studies across regions could elucidate generalities and hone hypotheses. Examining the impacts of agriculture on fish assemblages across disparate basins, ecosystems, and even ecotones would begin to test whether there are, in fact, generalizable relationships between landscapes and instream responses. Brown et al. (2009) evaluated the impacts of urbanization on fish assemblages across disparate basins, ecosystems, and ecotones to test for generalizable relationships between landscapes and instream responses, and found few. The development of a standardized GIS framework for collecting, organizing, and sharing riverine and landscape data (Hollenhorst et al., 2007; Brenden et al., 2006) and a standardized framework for effectively incorporating biological data into our digital representations of streams would facilitate such metaanalyses.

Living Reviews in Landscape Research

http://www.livingreviews.org/lrlr-2010-1 
Many projects have looked across multiple spatial extents to try and uncover mechanisms linking landscape patterns to instream conditions (e.g., Gido et al., 2006). The underlying concept of this family of analyses has been to compare the strength of correlations at different scales to identify the scale at which the mechanistic relationship exists, and from that, to develop a stronger theory about which mechanisms are causing the observed patterns. Such analyses have been used to identify relationships between land use or geology and fish assemblages in prairie steams in Kansas, USA (Gido et al., 2006); between geology or forest composition and instream habitats such as pool distribution in the forested mountains of the Pacific Northwest, USA (Burnett et al., 2007); and impacts of human disturbance on fish assemblages in flat to rolling topography in the Midwest USA (Wang et al., 2006b). Difficulties of this approach for uncovering mechanisms linking landscape patterns to instream conditions include a reliance on correlative patterns, lack of independence between potential predictor variables within and across scales, and arbitrary assignment of particular variables to a particular scale. For example, Gido et al. (2006) assigned stream order to the reach scale whereas some might argue that it could be applied to the catchment or site scale. Despite these limitations, there are many opportunities to improve our mechanistic understanding by incorporating the concept of scale and perhaps expanding it to include both extent and grain and both space and time.

Some progress may be made through application of better and more advanced sampling schemes. Although the technology is not new, advanced statistical sampling designs are increasingly being applied for assessing surface waters in the USA at riverscape (LaVigne et al., 2008a,b), state (Klauda et al., 1998), regional (Ode et al., 2005; Hughes et al., 2004), multi-state (Stoddard et al., 2005; McCormick et al., 2001) and national (USEPA, 2009; Paulsen et al., 2008) scales. Data from these monitoring programs are then used to link biological conditions and trends with landscape stressors. Further consideration of sampling scales for both instream responses and landscape predictors will make such sampling schemes more efficient.

Elucidating causal mechanisms at landscape scales is likely to remain a challenge. Development of more refined hypotheses should limit potential predictors a priori and reduce spurious effects. But, relationships between landscape conditions and instream responses are inherently noisy and difficult to model. Not all potential causal factors can be incorporated over large extents. For example, downstream factors are often ignored (Hitt and Angermeier, 2006; Pringle, 1997; Osborne and Wiley, 1992). As well, disturbance thresholds may obscure our ability to detect causal mechanisms (Brendan et al., 2008). Large-scale, long-term experiments would be ideal for uncovering mechanisms (Carpenter et al., 1995); however, these are extremely difficult to manage, usually prohibitively costly and, even when treatments can be applied over entire watersheds, identifying appropriate controls remains a challenge (Strayer et al., 2003). Analysis of existing "natural" experiments (space for time substitution, natural disturbances, before and after policy changes) is a promising approach (e.g., Paulsen et al., 2008; Van Sickle and Paulsen, 2008; Brazner et al., 2007).

\subsection{Spatio-temporal structure of human impacts}

Human impacts to landscapes occur worldwide (Hughes et al., 2005a; Rinne et al., 2005; Dodge, 1989). Everywhere humans alter landscapes, those landscape are tied to waterbodies that host ecological communities. We are now understanding that human disturbances to river landscapes such as land use (Vitousek et al., 1997, 1986), climate change (Matulla et al., 2007), non-indigenous species (Leprieur et al., 2008b), and morphological and hydrological alterations (Tockner et al., 2009; Nilsson et al., 2005; Tockner and Stanford, 2002; Dynesius and Nilsson, 1994) occur at a global scale. Studies from South America (e.g., Pinto et al., 2006; Tejerina-Garro et al., 2006; Hued and Bistoni, 2003), Asia (e.g., Fausch et al., 2010; An and Choi, 2003; Ganasan and Hughes, 1998; Houssain et al., 2001), Africa (e.g., Kleynhans, 1999; Toham and Teugels, 1999; Hugueny et al., 1996), New Zealand (e.g., Joy and Death, 2004), and Australia (e.g., Davies et al., 2006) 
have confirmed that human impacts across the landscape alter fish assemblages.

Many published analyses rely implicitly on the assumption that human activities are randomly distributed across the landscape. But, in fact, human activities are typically constrained by the very same environmental gradients as the biological assemblages of interest. For example, Yates and Bailey (2006) examined relationships between agriculture and landform across 191 basins. They found that agricultural intensity was constrained by geology, in particular drumlin formation and glacial landform type. Covariation between land use and several natural gradients (e.g., geology, soil, slope, elevation, precipitation, temperature) hinders associating land use with biological response (Whittier et al., 2006; Allen et al., 1999). As well, most human disturbances are highly correlated with each other leading to multiple stressors (Fausch et al., 2010) and lack of independence. For example, habitat degradation resulting from hydrological alterations is often accompanied by introductions of non-indigenous fish species that may become invasive, and the effects of these two types of disturbances to river ecosystems are generally impossible to assess separately (Light and Marchetti, 2007; Gurevitch and Padilla, 2004).

Legacy effects of human actions have been well documented in some places (e.g., Harding et al., 1998). Walter and Merritts (2008) detail how current stream form and bed load in many eastern US streams is largely a result of streams down-cutting through pond sediments deposited by many thousands of historic mill dams. And, Poissant et al. (2005) found genetic relationships among 12 brook trout populations to better reflect historical hydrologic structure and landscape features than those that were present at the time of the study. Because biological responses can lag behind changes to habitats, poor model fits and spurious results have been linked to a failure to consider historical factors (Van Sickle et al., 2004; Harding et al., 1998). Van Sickle et al. (2004) and Harding et al. (1998) both reported that historical agricultural land uses seriously limited current assemblage composition. Humphries and Winemiller (2009) describe the limitations of attempting to design riverine restoration projects without incorporating information about the distribution of once abundant fishes. The few existing studies of legacy effects (e.g., Walter and Merritts, 2008) demonstrate that they have a high potential to form constraints for current conditions, but that they are difficult to detect and quantify.

A major opportunity exists in modeling and quantifying the spatio-temporal structure of human impacts at landscape scales. Rather than considering, for example, "agriculture" simply as a predictive variable in isolation, we could consider its spatio-temporal context. We might consider the relationship of the distribution of agriculture to the distribution of urban areas or to the distribution of particular geologies and climatic conditions. We might also consider the relationship of current land use to past agricultural practices and the current distribution and implementation of agriculture to past patterns of human transportation and settlement. Perhaps riverine landscape ecology can benefit from tools developed in the social sciences to better address the complex nature of human impacts to landscapes.

\subsection{Statistical opportunities}

Johnson and Gage (1997) outlined a series of statistical challenges including (1) skewed data sets, (2) lack of true replication, (3) inherent multi-variate nature of research problems, and (4) colinearity and autocorrelation of landscape metrics. And, Durance et al. (2006) noted that largescale research is often plagued by (1) by non-independent sampling, (2) weak inference, (3) poor model testing or (4) model over-extrapolation. She claimed that these challenges prevent fisheries managers from quantifying the importance of large-scale, anthropogenic disturbances. Pyne et al. (2007) and King et al. (2005) have also identified serious challenges in relating catchment-scale landscape structure to local-scale biotic processes.

Statistical techniques for testing hypotheses rather than "data mining" have generally been applied despite the lack of strong hypotheses about causal links between landscapes and rivers.

Living Reviews in Landscape Research

http://www. livingreviews . org/lrlr-2010-1 
Beale et al. (2010) used a simulation study approach to assessing the performance of a suite of statistical models and model fitting methods to synthetic datasets designed to capture the range of issues commonly found in spatial data. They found that the generalized least squares family of models and a Bayesian implementation of the conditional auto-regressive model performed best. While the specific results of their study cannot be applied to all spatial datasets, they provide a good example and a reminder that simulation studies can be used to assess the relative performance of various statistical methods for managing the unique challenges of spatial analysis and can therefore help prevent misuse of techniques such as model selection or a priori removal of large-scale spatial trends.

There are also many opportunities for approaching these same data and questions with new or customized statistical tools. Durance et al. (2006), for example, suggest that an increased use of geostatistics, popular in landscape ecology, could improve our understanding of the scaledependence of landscape-fish relationships and improve our ability to test and develop hypotheses about landscape-scale impacts on fish assemblages. Covariance structure analysis (CSA) enabled Wehrly et al. (2006) to incorporate both direct and indirect landscape influences in models to predict and understand water temperature patterns in stream networks. Zorn and Wiley (2006) also used CSA to untangle the hierarchy of landscape and local influences on fish biomass distribution in streams. Random forest analysis offers a mechanism for teasing out the major predictor variables from large survey data sets (Cutler et al., 2007; Peters et al., 2007). A more customized technique for linking landscapes and rivers is offered by parametric distance weighting (Van Sickle and Johnson, 2008) which weights landscape and environmental variables by their flowpath distance from the stream. Partitioning variance of the response variable into independent components that reflect spatial variance, environmental variance, noise, and the spatial component of environmental influence is another opportunity (Borcard et al., 1992). Formalized data mining techniques, wavelet analysis, spatial statistics, graph theory (e.g., Schick and Lindley, 2007) and the use of neutral models (e.g., Gardner and Urban, 2007; Gardner et al., 1987) may also help us explore observed patterns and tease out relationships.

To best use results from riverine landscape analyses, we also need to better incorporate and communicate uncertainty into landscape-scale analyses (Burgman et al., 2005). Beginning steps for managing uncertainty include identification of sources of uncertainty, identification (and quantification) of biases that might result from uncertainty, and explicit recognition that management and policy decisions must be robust to known uncertainties. Emerging statistical methods, as described above, may be able to improve the quantification of uncertainty in parameters, in predictions, and across space and time. Mapping methods that can improve our ability to visualize the spatial dimensions of uncertainty will be welcome. The use of alternative scenarios (e.g., Jorgensen et al., 2009; Steel et al., 2008) is also a good tool (Peterson et al., 2003). Alternative scenarios, a method for structured thinking about large-scale patterns in an uncertain and uncontrollable world, are an opportunity both for managing uncertainty and communicating analytical results to inform decision-making.

\subsection{Defining the right metrics}

Landscapes are inherently heterogeneous and dynamic (Pickett and White, 1985). The idea of spatial heterogeneity, integral to landscape ecology, is not new to aquatic ecology (Thorp et al., 2006; Zalewski et al., 1997). Benda et al. (2004) have shown how climatic, hydrologic, and geomorphologic processes mediate the formation and maintenance of dynamic stream habitats. Stream biota, such as salmon (Waples et al., 2008), have evolved in this dynamic landscape. As a result, spatially explicit models have a high potential to address questions about the response of organisms to changing landscape patterns at broad spatial scales (Dunning et al., 1995; Turner et al., 1995). Flitcroft (2007) found hierarchical relationships between dynamic stream habitats and the spatial 
distributions of coho salmon. However, adequately capturing these dynamic systems with one or two metrics is a formidable challenge (Uuemaa et al., 2009).

Traditional landscape metrics capture either landscape content (e.g., percent of wetlands within a watershed) or landscape structure (spatial position of land use patches in relation to a waterbody). For instance, does it matter more that urban patches are next to a stream or that there is a large proportion of urban land uses in the watershed relative to forest? Careful application of landscape structure metrics has led to advances in our understanding of many ecological issues (Uuemaa et al., 2009, see Table 1). Examples in riverine ecology include Goetz and Fiske (2008); Van Sickle and Johnson (2008); King et al. (2005); Hunsaker and Hughes (2002) and Allan and Johnson (1997). Kearns et al. (2005) suggested that the lack of metrics that capture biologically relevant components of spatial pattern is, at least in part, responsible for the mixed conclusions of so many analyses attempting to link land use and instream responses. Therefore, future research should focus on metrics that are able to differentiate landscapes by their configuration as well as heterogeneity and patchiness. Patch density, size, and shape are measures of spatial complexity that could be tested for their ability to better develop linkages between landscape configuration and aquatic responses. Careful development of response metrics is also essential.

There are examples in which the careful development of novel metrics or new indices has advanced our understanding of landscape impacts to rivers. The landscape development index (LDI) of Brown et al. (Brown and Vivas, 2005; Brown and Moyle, 2005) uses energy use per unit area to estimate the cumulative impacts of human dominated activities over large extents. By lumping human activities, they have sidestepped the issues in Section 5.2 related to nonindependence of human impacts across the landscape. Another example of the use of novel metrics is Scott (2006). He modeled the effects of a trajectory of forest cover change over time on the ratio of endemic specialists to broad-ranged fishes. Using this approach, he quantified the loss of endemism as a result of urbanization.

\section{Conclusions}

Has new research utilized the strengths of new technologies or are we doing the same old stuff with more expensive data? There are formidable challenges to landscape riverine research but the field is evolving rapidly to meet the needs of both science and management. New technologies have enabled datasets beyond the dreams of most scientists even 30 years ago; but, we remain somewhat hindered by the size and novel nature of these data as well as by our inability to use traditional experimental methods for uncovering meaningful patterns in these data. Spatial data often contain many inter-correlated variables, all of which are potentially of interest, and the uncertainty of these data often has a spatial component that might vary from variable to variable. For example, pool depth might be more accurately measured in larger, wider river systems but hillslope might be more accurately quantified in steeper terrain. As our understanding of the accuracies and inaccuracies of spatial data evolves, we will be better able to utilize use the existing information. We also need to improve our ability to interpret and display spatial data in ways that communicate both accuracy and precision.

Have we incorporated key concepts from landscape ecology to improve our understanding of how landscapes affect rivers? The field of landscape ecology has played a large role in the development of landscape riverine research. The importance of pattern-process interrelationships, connectivity, scale, and fragmentation has guided the development of new work on landscapes and rivers. However, adaptation of these concepts to riverine systems remains a challenge. For example, connectivity in a terrestrial landscape mosaic is quite different from connectivity along a riverine network with unidirectional flow or across an active floodplain with multiple channels. We need to expand our thinking about aquatic connectivity. As another exam-

Living Reviews in Landscape Research

http://www. livingreviews.org/lrlr-2010-1 
ple, landscape riverine research will benefit from a broader exploration of the significance of scale to include spatial grain and temporal scale.

Have we been able to use landscape analyses to address management and policy needs? Large-scale analysis of riverine systems has been effective in a wide range of applications. It has been critical in the development of conservation networks and monitoring programs. It has improved our understanding and management of riparian areas in diverse ecosystems. It has led to the improved use of a wide variety of bio-assessment tools. Restoration and rehabilitation prioritization schemes have been enhanced. And lastly, it may be a useful tool for management in the face of climate change. The impact of landscape riverine research has been concentrated in highly developed nations where data and resources are available. As we envisage methods for collecting and combining data across global scales, there will be opportunities for this type of research to affect policies in less developed countries.

\section{Opportunities in landscape-scale riverine research}

- There is a need to develop tools for studying mechanistic rather than correlative relationships over large spatial extents. Multi-scale analyses, multi-basin studies, combined process and statistical models, and large-scale experiments can all be harnessed to develop and test generalized theories about how landscape features drive instream responses. Working over larger and larger extents and/or work that leverages long-term data sets may also enable us to increase our sample sizes and generalize results.

- Another opportunity is to shift our perceptions about anthropogenic impacts. First, we must more explicitly model the impacts of economic incentives, human behavior, and population growth patterns on ecological systems. Second, we can benefit from considering the spatiotemporal aspect of human impacts such as the correlation between human development, environmental gradients, and the legacies of past land uses.

- Finally, there are opportunities for a greater number of researchers to incorporate the new statistical tools being designed specifically for linking landscapes to rivers. Quantitative opportunities may also be as simple as defining both landscape and response metrics in novel ways that can more efficiently capture the social, physical, and ecological processes of interest.

\section{Acknowledgements}

We thank Beth Sanderson and Mindi Sheer, NOAA's NW Fisheries Science Center, and Lucinda Johnson, University of Minnesota, for careful and constructive manuscript reviews that substantially improved the manuscript. Sean Luis provided endless hours of assistance tracking down and formatting references. This manuscript was stimulated by presentations during, and discussions following, the 2008 annual meeting of the International Association of Landscape Ecology in Wageningen, The Netherlands. Partial funding for manuscript preparation was provided by U.S. Environmental Protection Agency grant RM832827 to Oregon State University, the Austrian American Education Commission, and the Fulbright Scholar Program. 


\section{A Appendix: Landscape perspectives of rivers}

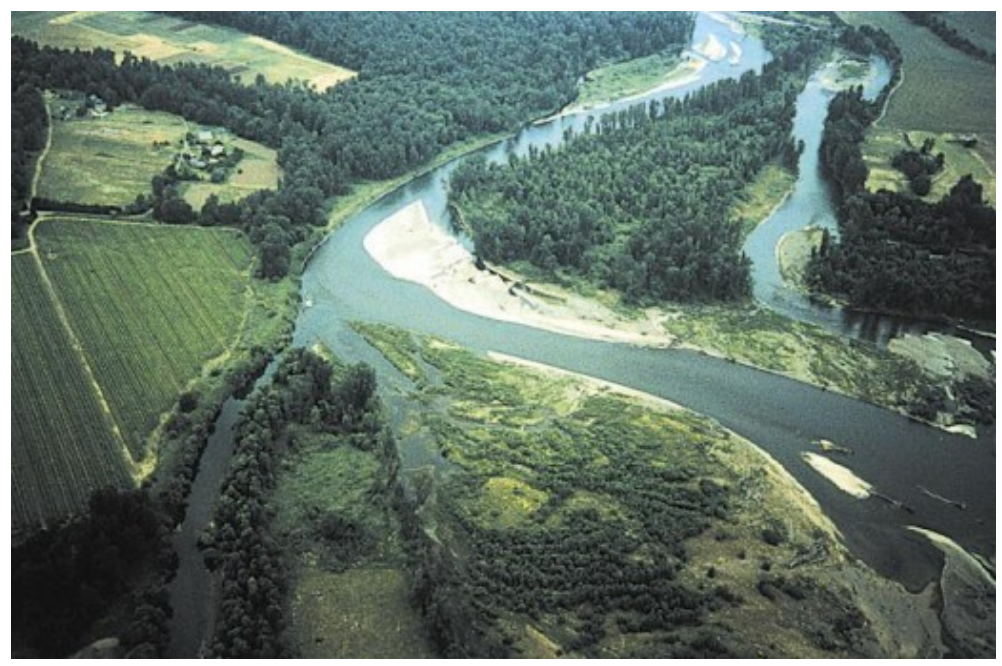

Figure I: The Upper Mainstem Willamette River, Oregon, USA. Photo by Steve Cline, USEPA-Corvallis. Despite being channelized in the early 20th century and having multiple hydropower dams in its major tributaries, the upper mainstem of this floodplain river retains channel complexity in the form of side channels, islands, and alcoves.

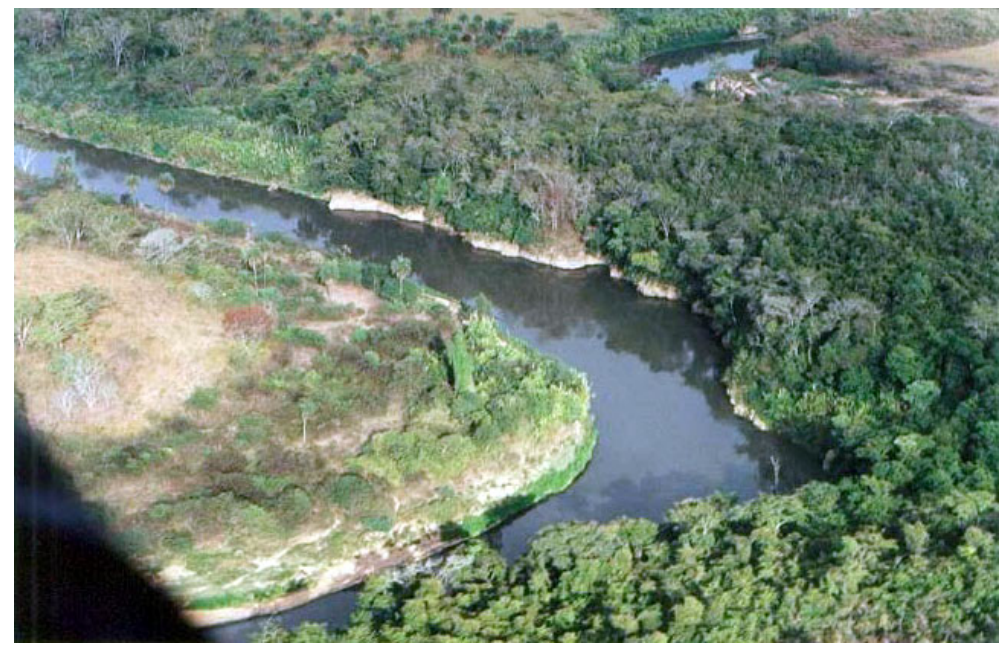

Figure II: Rio das Velhas, Minas Gerais, Brazil. Photo taken by Carlos Alves, Manuelzao Project. Lacking mainstem or major tributary dams, the das Velhas floods during the rainy season and supports multiple, permanent, off-channel lakes (lagoas) providing reproductive and rearing habitat for aquatic vertebrates. 


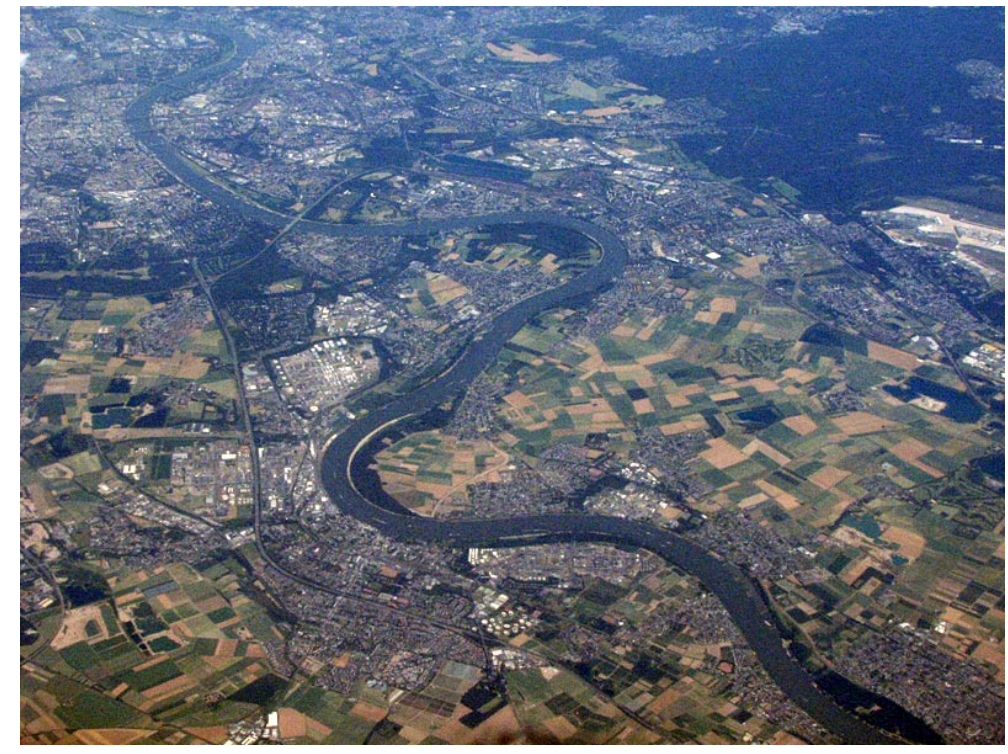

Figure III: Upper Danube River, Germany. Photo taken by Ashley Steel. This large floodplain river has lost much of its floodplain connectivity as a result of channelization and system-wide dams and locks.

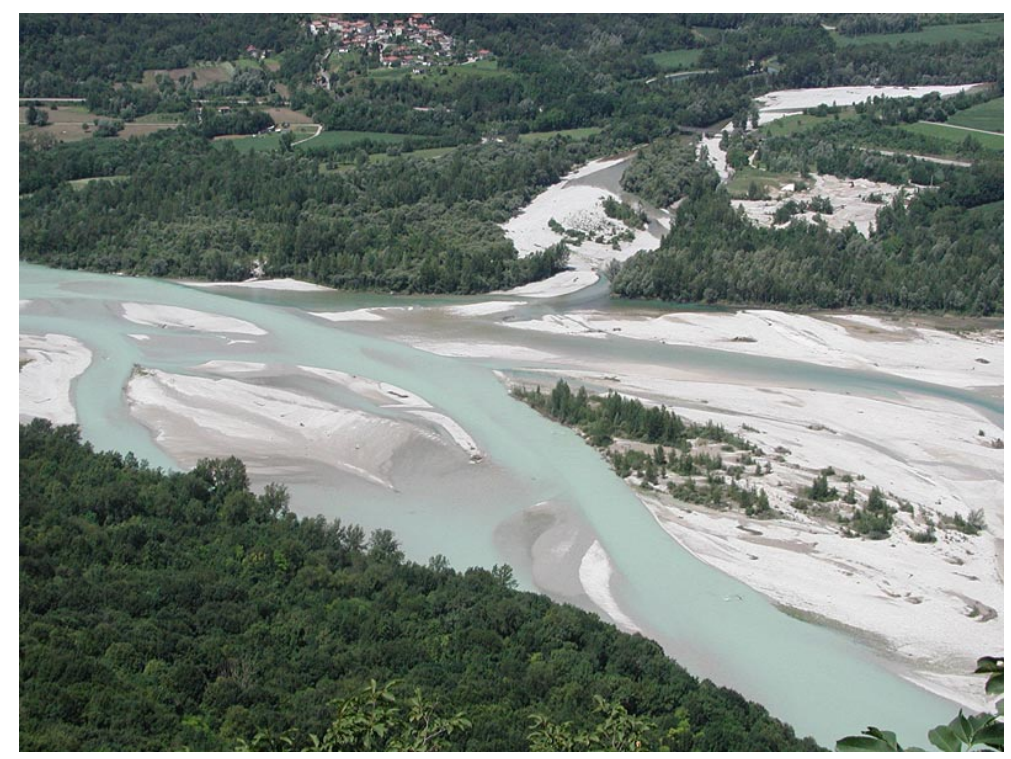

Figure IV: Tagliamento River, Italy. Photo taken by Susanne Muhar. The Tagliamento is one of the largest undammed rivers in western Europe and its braided and anastamosed channels are indicative of high bedload from the Alps. 


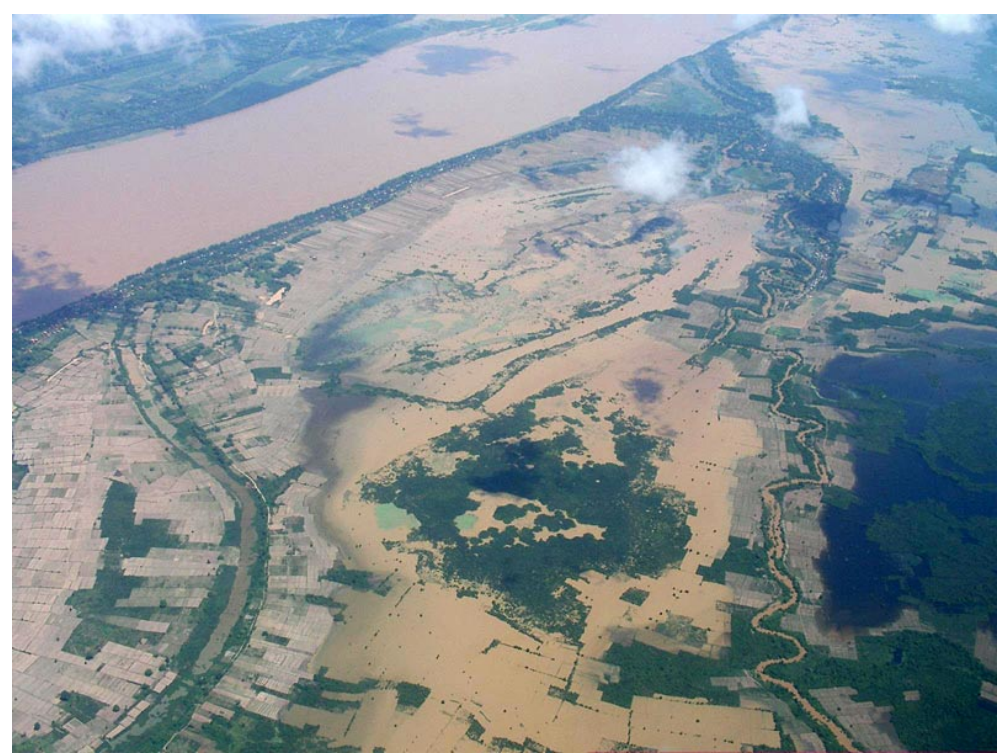

Figure V: Mekong River and its tributary in Cambodia. Photo taken by Seiichi Nohara during the rainy season. The tributary of this floodplain river is visible only because the riparian forest canopy is barely higher than the water level.

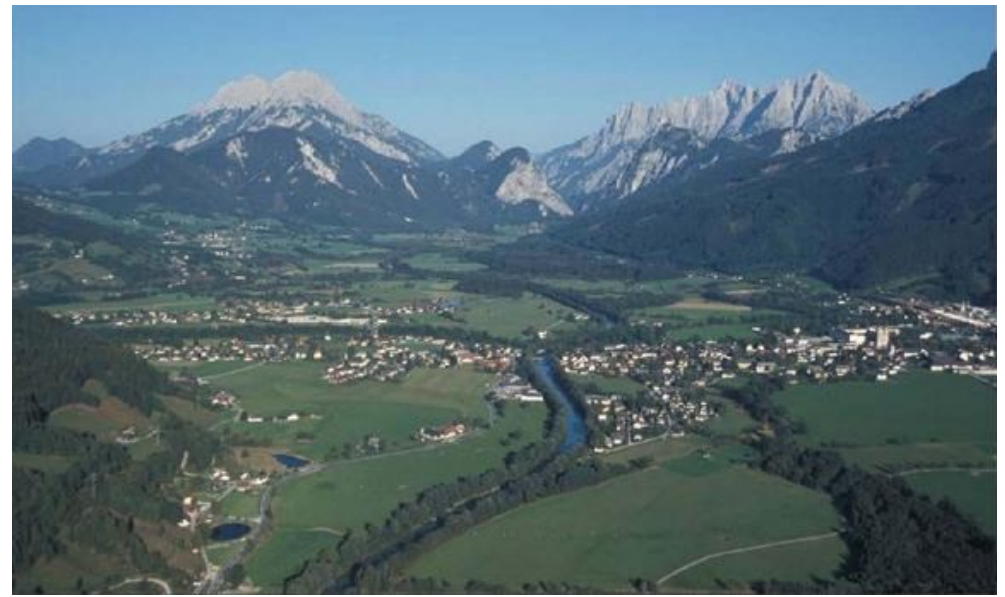

Figure VI: The River Enns, Styria, Austria. Photo from Gesaeuse National Park. Hydropower dams, canals, and channelization limit connectivity of the Enns with its floodplain. 


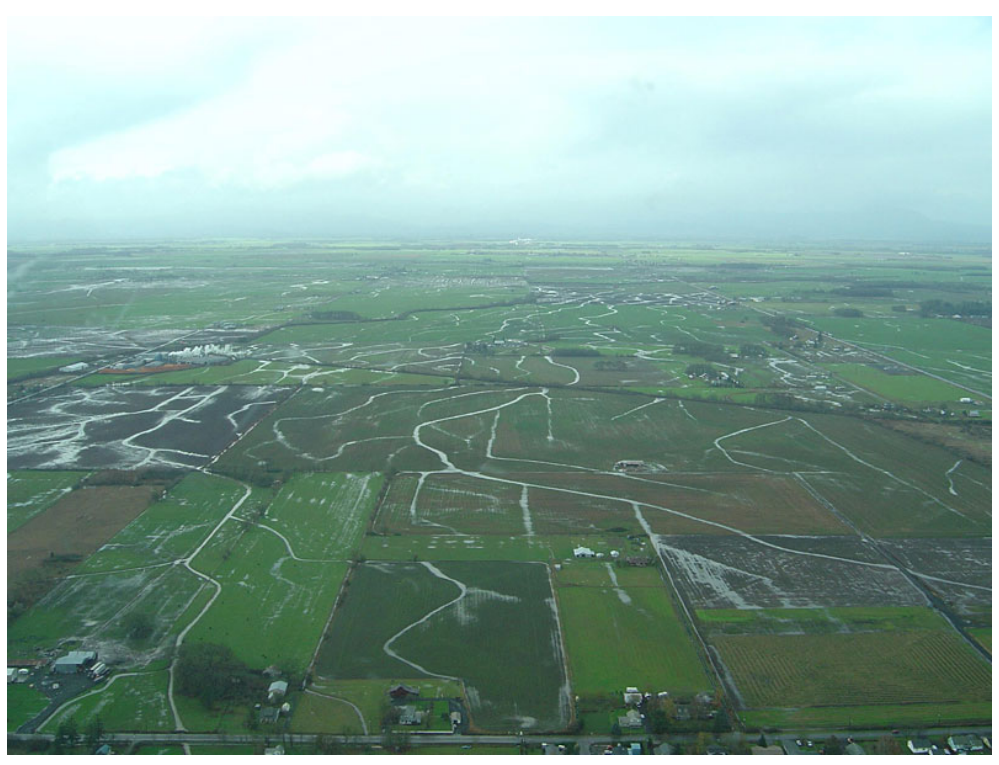

Figure VII: Intermittent tributaries of the Calapooia River, Oregon, USA. Photo by Randy Colvin, Department of Fisheries and Wildlife, Oregon State University. Nearly all of the visible channels (agricultural ditches) are only wet during the rainy season, yet they provide overwintering refuge habitat for spawning and rearing native fish, including salmonids. 


\section{References}

Alberti, M., Booth, D., Hill, K., Coburn, B., Avolio, C., Coe, S. and Spirandelli, D. (2007), "The impact of urban patterns on aquatic ecosystem: An empirical analysis in the Puget lowland sub-basins", Landscape and Urban Planning, 80: 345-361, [DOI]. (Cited on page 21.)

Alexander, G.G. and Allan, J.D. (2006), "Stream restoration in the Upper Midwest, USA", Restoration Ecology, 14: 595-604, [DOI]. (Cited on page 25.)

Allan, J.D. (2004a), "Landscapes and riverscapes: the influence of land use on stream ecosystems", Annual Review of Ecology, Evolution, and Systematics, 35: 257-284, [DOI]. (Cited on pages 13, 14, 19, 21, 22, and 26.)

Allan, J.D. (2004b), "Influence of land use and landscape setting on the ecological status of rivers", Limnetica, 23(3-4): 187-198. (Cited on page 13.)

Allan, J.D. and Johnson, L.B. (1997), "Catchment-scale analysis of aquatic ecosystems", Freshwater Biology, 37(1): 107-111, [DOI]. (Cited on pages 12 and 30.)

Allen, A.P., Whittier, T.R., Kaufmann, P.R., Larsen, D.P., O’Connor, R.J., Hughes, R.M., Stemberger, R.S., Dixit, S.S., Brinkhurst, R.O., Herlihy, A.T. and Paulsen, S.G. (1999), "Concordance of taxonomic composition patterns across multiple lake assemblages: effects of scale, body size, and land use", Canadian Journal of Fisheries and Aquatic Sciences, 56(11): 2029-2040, [DOI]. (Cited on pages 23 and 28.)

An, K.W. and Choi, S.S. (2003), "An assessment of aquatic ecosystem health in a temperate watershed using the index of biological integrity", Journal of Environmental Science and Health (A), 38: 1115-1130, [DOI]. (Cited on page 27.)

Anderson, J., Arblaster, K., Bartley, J., Cooper, T., Kettunen, M., Kaphengst, T., Leipprand, A., Laaser, C., Umpfenbach, K., Kuusisto, E., Lepistö, A. and Holmberg, M. (2008), "Climate change-induced water stress and its impact on natural and managed ecosystems", IP/A/CLIM/ST/2007-06, Brussels (European Parliament). Online version (accessed 21 October 2009): http://ecologic.eu/2333. (Cited on page 24.)

Angermeier, P.L. and Winston, M.R. (1999), "Characterizing fish community diversity across virginia landscapes: Prerequisite for conservation", Ecological Applications, 9(1): 335-349, [DOI]. (Cited on page 12.)

Aspinall, R.J., Marcus, W.A. and Boardman, J.W. (2002), "Considerations in collecting, processing, and analysing high spatial resolution hyperspectral data for environmental investigations", Journal of Geographical Systems, 4(1): 15-29, [DOI]. (Cited on page 10.)

Bacalbasa-Dobrovici, N. (1989), "The Danube river and its fishery", in Dodge, D.P., ed., Proceedings of the International Large River Symposium (LARS), Honey Harbour, Ontario, Canada, September 14-21, 1986, Canadian Special Publication of Fisheries and Aquatic Sciences, 106, pp. 110-127, Ottawa (Fisheries and Oceans Canada). (Cited on page 20.)

Baker, J.P., Hulse, D.W., Gregory, S.V., White, D., Van Sickle, J., Berger, P.A., Dole, D. and Schumaker, N.H. (2004), "Alternative futures for the Willamette River basin, Oregon", Ecological Applications, 14: 313-324, [DOI]. (Cited on page 24.)

Ballinger, A. and Mac Nally, R. (2006), "The landscape context of flooding in the Murray-Darling Basin", Advances in Ecological Research, 39: 85-105, [DOI]. (Cited on page 21.) 
Baran, E., Jantunen, T. and Chong, C.K. (2007), "Values of inland fisheries in the Mekong River Basin", Phnom Penh (WorldFish Center). (Cited on page 20.)

Barker, L.S., Felton, G.K. and Russek-Cohen, E. (2006), "Use of Maryland biological stream survey data to determine effects of agricultural riparian buffers on measures of biological stream health", Environmental Monitoring and Assessment, 117(1-3): 1-19, [DOI]. (Cited on pages 22 and 23.)

Battin, J., Wiley, M.W., Ruckelshaus, M.H., Palmer, R.N., Korb, E., Bartz, K.K. and Imaki, H. (2007), "Projected impacts of climate change on salmon habitat restoration", Proceedings of the National Academy of Sciences of the USA, 104(16): 6720-6725, [DOI]. (Cited on page 24.)

Beale, C.M., Lennon, J.J., Yearsley, J.M., Brewer, M.J. and Elston, D.A. (2010), "Regression analysis of spatial data", Ecology Letters, 13: 246-264, [DOI]. (Cited on page 29.)

Beechie, T. and Bolton, S. (1999), "An approach to restoring salmonid habitat-forming processes in Pacific Northwest watersheds", Fisheries, 24: 6-15, [DOI]. (Cited on page 23.)

Benda, L., Poff, N.L., Miller, D., Dunne, T., Reeves, G., Pess, G. and Pollock, M. (2004), "The network dynamics hypothesis: How channel networks structure riverine habitats", BioScience, 54(5): 413-427, [DOI]. (Cited on pages 18 and 29.)

Bernhardt, E.S., Palmer, M.A., Allan, J.D., Alexander, G.G., Barnas, K., Brooks, S., Carr, J., Clayton, S., Dahm, C., Follstad-Shah, J., Galat, D., Gloss, S., Goodwin, P., Hart, D., Hassett, B., Jenkinson, R., Katz, S., Kondolf, G.M., Lake, P.S., Lave, R., Meyer, J.L., O’Donnell, T.K., Pagano, L., Powell, B. and Sudduth, E. (2005), "Restoration of US rivers: a national synthesis", Science, 308: 636-637. (Cited on page 25.)

Bilby, R.E. and Mollot, L.A. (2008), "Effect of changing land use patterns on the distribution of coho salmon (Oncorhynchus kisutch) in the Puget Sound region", Canadian Journal of Fisheries and Aquatic Sciences, 65(10): 2138-2148, [DOI]. (Cited on page 21.)

Bjerklie, D.M., Dingman, S.L., Vorosmarty, C.J., Bolster, C.H. and Congalton, R.G. (2003), "Evaluating the potential for measuring river discharge from space", Journal of Hydrology, 278: 17-38, [DOI]. (Cited on page 16.)

Bjerklie, D.M., Moller, D., Smith, L.C. and Dingman, S.L. (2005), "Estimating discharge in rivers using remotely sensed hydraulic information", Journal of Hydrology, 309: 191-209, [DOI]. (Cited on page 16.)

Bohn, B.A. and Kershner, J.L. (2008), "Establishing aquatic restoration priorities using a watershed approach", Journal of Environmental Management, 64: 355-363. (Cited on page 24.)

Bonar, S.A., Hubert, W.A. and Willis, D.W., eds. (2009), Standard Methods for Sampling North American Freshwater Fishes, Bethesda, MD (American Fisheries Society). (Cited on page 25.)

Booth, D.B., Karr, J.R., Schauman, S., Konrad, C.P., Morley, S.A., Larson, M.G. and Burgess, S.J. (2004), "Reviving urban streams: Land use, hydrology, biology, and human behavior", Journal of the American Water Resources Association, 40: 1351-1364, [DOI]. (Cited on pages 21 and 24.)

Borcard, D., Legendre, P.L. and Drapeau, P. (1992), "Partialling out the spatial component of ecological variation", Ecology, 73: 1045-1055, [DOI]. (Cited on page 29.)

Bramblett, R.G., Johnson, T.R., Zale, A.V. and Heggem, D.G. (2005), "Development and evaluation of a fish assemblage index of biotic integrity for northwestern Great Plains streams", Transactions of the American Fisheries Society, 134(3): 624-640, [DOI]. (Cited on page 23.) 
Brazner, J.C., Danz, N.P., Trebitz, A.S., Niemi, G.J., Regal, R.R., Hollenhorst, T., Host, G.E., Reavie, E.D., Brown, T.N., Hanowski, J.M., Johnston, C.A., Johnson, L.B., Howe, R.W. and Ciborowski, J.J.H. (2007), "Responsiveness of Great Lakes wetland indicators to human disturbances at multiple spatial scales: A multi-assemblage assessment", Journal of Great Lakes Research, 33: 42-66, [DOI]. (Cited on pages 23 and 27.)

Brendan, T.O., Wang, L. and Su, Z. (2008), "Quantitative identification of disturbance thresholds in support of aquatic resource management", Environmental Management, 42: 821-832, [DOI]. (Cited on page 27.)

Brenden, T.O., Clark Jr, R.D., Cooper, A.R., Seelbach, P.W., Wang, L., Aichele, S.S., Bissell, E.G. and Stewart, J.S. (2006), "A GIS framework for collecting, managing, and analyzing multiscale landscape variables across large regions for river conservation and management", in Hughes, R.M., Wang, L. and Seelbach, P.W., eds., Landscape Influences on Stream Habitats and Biological Assemblages, Proceedings of the Symposium held in Madison, Wisconsin, USA, 25-26 August 2004, AFS Symposium, 48, pp. 49-74, Bethesda, MD (American Fisheries Society). (Cited on page 26.)

Brown, L.R. and Moyle, P.B. (2005), "Native fishes of the Sacramento-San Joaquin drainage: A history of decline", in Rinne, J.N., Hughes, R.M. and Calamusso, B., eds., Historical Changes in Large River Fish Assemblages of the Americas, Proceedings of the Symposium held in Phoenix, Arizona, USA, 21 August 2001, AFS Symposium, 45, pp. 75-98, Bethesda, MD (American Fisheries Society). (Cited on page 30.)

Brown, L.R., Gray, R.H., Hughes, R.M. and Meador, M.R., eds. (2005), Effects of urbanization on stream ecosystems, Proceedings of the Symposium held in Quebec City, Quebec, Canada, 11 - 12 August 2003, AFS Symposium, 47, Bethesda, MD (American Fisheries Society). (Cited on pages 18 and 20.)

Brown, L.R., Gregory, M.B. and May, J.T. (2009), "Relation of urbanization to stream fish assemblages and species traits in nine metropolitan areas of the United States", Urban Ecosystems, 12(4): 391-416, [DOI]. (Cited on pages 25 and 26.)

Brown, M.T. and Vivas, M.B. (2005), "Landscape development intensity index", Environmental Monitoring and Assessment, 101: 289-309, [DOI]. (Cited on page 30.)

Burcher, C.L., Valett, H.M. and Benfield, B.F. (2007), "The land-cover cascade: Relationships coupling land and water", Ecology, 88(1): 228-242, [DOI]. (Cited on page 12.)

Burgman, M.A., Lindenmayer, D.B. and Elith, J. (2005), "Managing landscapes for conservation under uncertainty", Ecology, 86(8): 2007-2017, [DOI]. (Cited on page 29.)

Burnett, K.M., Reeves, G.H., Miller, D.J., Clarke, S., Vance-Borland, K. and Christiansen, K. (2007), "Distribution of salmon-habitat potential relative to landscape characteristics and implications for conservation", Ecological Applications, 17(1): 66-80, [DOI]. (Cited on pages 6, 24, and 27.)

Calabrese, J.M. and Fagan, W.F. (2004), "A comparison-shopper's guide to connectivity metrics", Frontiers in Ecology and the Environment, 2(10): 529-536. (Cited on page 19.)

Carlisle, D.M., Hawkins, C.P., Meador, M.R., Potapova, M. and Falcone, J. (2008), "Biological assessments of Appalachian streams based on predictive models for fish, macroinvertebrate, and diatom assemblages", Journal of the North American Benthological Society, 27(1): 16-37, [DOI]. (Cited on pages 23 and 26.)

Living Reviews in Landscape Research

http://www. livingreviews.org/lrlr-2010-1 
Carmichael, R.W. and Taylor, B.J. (2010), "Conservation and Recovery Plan for Oregon Steelhead Populations in the Middle Columbia River Steelhead Distinct Population Segment", Salem, OR (Oregon Department of Fish \& Wildlife). Online version (accessed 10 March 2010):

http://www.dfw.state.or.us/fish/CRP/mid_columbia_river_plan.asp. (Cited on page 6.)

Carpenter, S.R., Chisholm, S.W., Krebs, C.J., Schindler, D.W. and Wright, R.F. (1995), "Ecosystem Experiments", Science, 269: 324-327, [DOI]. (Cited on page 27.)

Clarke, A.D., Telmer, K.H. and Shrimpton, J.M. (2007), "Habitat use and movement patterns for a fluvial species, the Arctic grayling, in a watershed impacted by a large reservoir: evidence from otolith microchemistry", Journal of Applied Ecology, 44: 1156-1165, [DOI]. (Cited on page 18.)

Clausen, R. and York, R. (2008), "Economic growth and marine biodiversity: Influence of human social structure on decline of marine trophic levels", Conservation Biology, 22(2): 458-466, [DOI]. (Cited on page 21.)

Cote, D., Kehler, D.G., Bourne, C. and Wiersma, Y.F. (2009), "A new measure of longitudinal connectivity for stream networks", Landscape Ecology, 24: 101-113, [DOI]. (Cited on page 19.)

Cowley, D.E. (2006), "Strategies for ecological restoration of the Middle Rio Grande in New Mexico and recovery of the endangered Rio Grande silvery minnow", Reviews in Fisheries Science, 14 (1-2): 169-186, [DOI]. (Cited on page 22.)

Creque, S.M., Rutherford, E.S. and Zorn, T.G. (2005), "Use of GIS-derived landscape-scale habitat features to explain spatial patterns of fish density in Michigan rivers", North American Journal of Fisheries Management, 25(4): 1411-1425, [DOI]. (Cited on pages 19 and 26.)

Crozier, L.G., Hendry, A.P., Lawson, P.W., Quinn, T.P., Mantua, N.J., Battin, J. and Shaw, R.G. (2008), "Potential responses to climate change in organisms with complex life histories: Evolution and plasticity in Pacific salmon", Evolutionary Applications, 1(2): 252-270, [DOI]. (Cited on page 21.)

Cutler, D.R., Edwards Jr, T.C., Beard, K.H., Cutler, A., Hess, K.T., Gibson, J. and Lawler, J.L. (2007), "Random forests for classification in ecology", Ecology, 88: 2783-2792, [DOI]. (Cited on page 29.)

Dauwalter, D.C. and Jackson, J.R. (2004), "A provisional fish index of biotic integrity for assessing Ouachita Mountains streams in Arkansas, USA", Environmental Monitoring and Assessment, 91(3): 27-57, [DOI]. (Cited on pages 23 and 26.)

Davies, P.E., Harris, J., Hillman, T. and Walker, K. (2006), "Sustainable Rivers Audit (SRA) Implementation Period 1 (2004-2005) Progress Report: A Report to the Murray-Darling Basin Ministerial Council prepared by the Independent Sustainable Rivers Audit Group", $M D B C$ Publication, No. 09/06, Canberra (Murray-Darling Basin Commission). Online version (accessed 5 March 2010):

http://publications.mdbc.gov.au/view.php?view=52. (Cited on pages 9, 25, and 27.)

Dodge, D.P., ed. (1989), Proceedings of the International Large River Symposium (LARS), Honey Harbour, Ontario, Canada, September 14-21, 1986, Canadian Special Publication of Fisheries and Aquatic Sciences, 106, Ottawa (Fisheries and Oceans Canada). (Cited on page 27.)

Drummond, J. and Barros-Platiau, A.F.G. (2006), "Brazilian environmental laws and policies 1934-2002: a critical overview", Law \& Policy, 28: 83-108, [DOI]. (Cited on page 9.) 
Dunham, J., Baxter, C., Fausch, K., Fredenberg, W., Kitano, S., Koizume, I., Morita, K., Nakamura, T., Rieman, B., Savvaitova, K., Stanford, J., Taylor, E. and Yamamoto, S. (2008), "Evolution, ecology, and conservation of Dolly Varden, white-spotted char, and bull trout", Fisheries, 33: 537-550. (Cited on page 22.)

Dunning, J.B., Danielson, B.J., Noon, B.R., Root, T.L., Lamberson, R.H. and Stevens, E.E. (1995), "Spatially explicit population models: current forms and future uses", Ecological Applications, 5: 3-11, [DOI]. (Cited on page 29.)

Durance, I., Lepichon, C. and Ormerod, S.J. (2006), "Recognizing the importance of scale in the ecology and management of riverine fish", River Research and Applications, 22(10): 1143-1152, [DOI]. (Cited on pages 13, 15, 18, 19, 26, 28, and 29.)

Dynesius, M. and Nilsson, C. (1994), "Fragmentation and flow regulation of river systems in the northern third of the world", Science, 266: 753-762, [DOI]. (Cited on page 27.)

Ebel, W.J., Becker, C.D., Mullan, J.W. and Raymond, H.L. (1989), "The Columbia River: toward a holistic understanding", in Dodge, D.P., ed., Proceedings of the International Large River Symposium (LARS), Honey Harbour, Ontario, Canada, September 14-21, 1986, Canadian Special Publication of Fisheries and Aquatic Sciences, 106, pp. 205-219, Ottawa (Fisheries and Oceans Canada). (Cited on page 20.)

Eikaas, H.S., Kliskey, A.D. and McIntosh, A.R. (2005), "Spatial modeling and habitat quantification for two diadromous fish in New Zealand streams: GIS-based approach with application for conservation management", Environmental Management, 36(5): 726-740, [DOI]. (Cited on page 22.)

Ekness, P. and Randhir, T.O. (2007), "Effects of riparian areas, stream order, and land use disturbance on watershed-scale habitat potential: An ecohydrologic approach to policy", Journal of the American Water Resources Association, 43(6): 1468-1482, [DOI]. (Cited on page 22.)

Fagan, W.F. (2002), "Connectivity, fragmentation, and extinction risk in dendritic metapopulations", Ecology, 83(12): 3243-3249, [DOI]. (Cited on page 19.)

Fagan, W.F., Unmack, P.J., Burgess, C. and Minckley, W.L. (2002), "Rarity, fragmentation, and extinction risk in desert fishes", Ecology, 83(12): 3250-3256, [DOI]. (Cited on page 19.)

Fausch, K.D., Torgersen, C.E., Baxter, C.V. and Hiram, W.L. (2002), "Landscapes to riverscapes: Bridging the gap between research and conservation of stream fishes", BioScience, 52(6): 483498, [DOI]. (Cited on pages 12, 18, and 19.)

Fausch, K.D., Baxter, C.V. and Murakami, M. (2010), "Multiple stressors in north temperate streams: lessons from linked forest-stream ecosystems in northern Japan", Freshwater Biology, 55(s1): 120-134, [DOI]. (Cited on pages 27 and 28.)

Feist, B.E., Steel, E.A., Pess, G.R. and Bilby, R.E. (2003), "The influence of scale on salmon habitat restoration priorities", Animal Conservation, 6(3): 271-282, [DOI]. (Cited on pages 19 and 26.)

Feist, B.E., Steel, E.A., Jensen, D.W. and Sather, D.N. (2010), "Does the scale of our observational window affect our conclusions about correlations between endangered salmon populations and their habitat?", Landscape Ecology, 25(5): 727-743, [DOI]. (Cited on pages 18, 19, and 26.)

FEMAT (1993), "Forest ecosystem management: An ecological, economic, and social assessment. Report of the Forest Ecosystem Management Assessment Team", 1993-793-071, Washington, DC (U.S. Government Printing Office). (Cited on page 22.)

Living Reviews in Landscape Research

http://www. livingreviews.org/lrlr-2010-1 
Feurer, D., Bailly, J.-S., Puech, C., Coarer, Y.L. and Viau, A.A. (2008), "Very-high-resolution mapping of river-immersed topography by remote sensing", Progress in Physical Geography, 32 (4): 403-419, [DOI]. (Cited on page 17.)

Filipe, A.F., Marques, T.A., Seabra, S., Tiago, P., Ribeiro, F., Da Costa, L.M., Cowx, I.G. and Collares-Pereira, M.J. (2004), "Selection of priority areas for fish conservation in Guadiana River Basin, Iberian peninsula", Conservation Biology, 18(1): 189-200, [DOI]. (Cited on page 21.)

Fitzpatrick, F.A., Scudder, B.C., Lenz, B.N. and Sullivan, D.J. (2001), "Effects of multi-scale environmental characteristics on agricultural stream biota in eastern Wisconsin", Journal of the American Water Resources Association, 37: 1489-507, [DOI]. (Cited on page 19.)

Flebbe, P.A., Roghair, L.D. and Bruggink, J.L. (2006), "Spatial modeling to project southern Appalachian trout distribution in a warmer climate", Transactions of the American Fisheries Society, 135(5): 1371-1382, [DOI]. (Cited on pages 21 and 24.)

Flitcroft, R.L. (2007), Regions to Streams: Spatial and Temporal Variation in Stream Occupancy Patterns of Coho Salmon (Oncorhynchus kisutch) on the Oregon Coast, Ph.D. Thesis, Oregon State University, Corvallis. URL (accessed 21 October 2009): http://hdl.handle.net/1957/7262. (Cited on page 29.)

Flotemersch, J.E., Stribling, J.B., Hughes, R.M., Reynolds, L., Paul, M.J. and Wolter, C. (2010), "Site length for biological assessment of boatable rivers", River Research and Applications, in press, [DOI]. (Cited on page 25.)

Fonstad, M.A. and Marcus, M.A. (2005), "Remote sensing of stream depths with hydraulically assisted bathymetry (HAB) models", Geomorphology, 72(1-4): 320-339, [DOI]. (Cited on page 16.)

Forman, R.T.T. and Godron, M. (1986), Landscape Ecology, New York (Wiley). (Cited on page 18.)

Freeman, R.E., Stanley, E.H. and Turner, M.G. (2003), "Analysis and conservation implications of landscape change in the Wisconsin River floodplain, USA", Ecological Applications, 13(2): 416-431, [DOI]. (Cited on pages 22 and 24.)

Frissell, C.A., Liss, W.J., Warren, C.E. and Hurley, M.D. (1986), "A hierarchical framework for stream habitat classification: Viewing streams in a watershed context", Environmental Management, 10(2): 199-214, [DOI]. (Cited on pages 5 and 12.)

Fritsch, A.J. (1872), "Die Wirbeltiere Böhmens: Ein Verzeichnis aller bisher in Böhmen beobachteten Säugetiere, Vögel, Amphibien und Fische", Archiv für die naturwissenschaftliche Landesdurchforschung von Böhmen, 2: 1-152. (Cited on page 19.)

Fukushima, M., Kemeyama, S., Kaneko, M., Nakao, K. and Steel, E.A. (2007), "Modelling the effects of dams on freshwater fish distributions in Hokkaido, Japan", Freshwater Biology, 52: 1511-1524, [DOI]. (Cited on page 20.)

Fullerton, A.F., Steel, E.A., Caras, Y., Sheer, M., Olson, P. and Kaje, J. (2009), "Putting watershed restoration in context: Alternative future scenarios influence management outcomes", Ecological Applications, 19(1): 218-235, [DOI]. (Cited on page 24.)

Fullerton, A.H., Beechie, T.J., Baker, S.E., Hall, J.E. and Barnas, K.A. (2006), "Regional patterns of riparian characteristics in the interior Columbia River basin, Northwestern USA: applications for restoration planning", Landscape Ecology, 21(8): 1347-1360, [DOI]. (Cited on pages 23 and 24.) 
Ganasan, V. and Hughes, R.M. (1998), "Application of an index of biological integrity (IBI) to fish assemblages of the rivers Khan and Kshipra (Madhya Pradesh), India", Freshwater Biology, 40: 367-383, [DOI]. (Cited on page 27.)

Ganio, L.M., Torgersen, C.E. and Gresswell, R.E. (2005), "A geostatistical approach for describing spatial pattern in stream networks", Frontiers in Ecology and the Environment, 3(3): 138-144, [DOI]. (Cited on page 19.)

Gardner, R.H. and Urban, D.L. (2007), "Neutral models for testing landscape hypotheses", Landscape Ecology, 22(1): 15-29, [DOI]. (Cited on page 29.)

Gardner, R.H., Milne, B.T., Turner, M.G. and O’Neill, R.V. (1987), "Neutral models for the analysis of broad-scale landscape pattern", Landscape Ecology, 1: 19-28, [DOI]. (Cited on page 29.)

Gergel, S.E., Turner, M.G., Miller, J.R., Melack, J.M. and Stanley, E.H. (2002), "Landscape indicators of human impacts to riverine systems", Aquatic Sciences, 64(2): 118-128, [DOI]. (Cited on page 18.)

Gido, K.B., Falke, J.A., Oakes, R.M. and Hase, K.J. (2006), "Fish-habitat relations across spatial scales in prairie streams", in Hughes, R.M., Wang, L. and Seelbach, P.W., eds., Landscape Influences on Stream Habitats and Biological Assemblages, Proceedings of the Symposium held in Madison, Wisconsin, USA, 25-26 August 2004, AFS Symposium, 48, pp. 265-285, Bethesda, MD (American Fisheries Society). (Cited on page 27.)

Gilliom, R.J., Hamilton, P.A. and Miller, T.L. (2001), "The National Water-Quality Assessment Program: Entering a new decade of investigations", U.S. Geological Survey Fact Sheet, 071-01, Reston, VA (USGS). Online version (accessed 21 October 2009): http://pubs.water.usgs.gov/fs07101. (Cited on page 25.)

Goetz, S. and Fiske, G. (2008), "Linking the diversity and abundance of stream biota to landscapes in the mid-Atlantic USA", Remote Sensing of Environment, 112(11): 4075-4085, [DOI]. (Cited on page 30.)

Govender, M., Chetty, K. and Bulcock, H. (2007), "A review of hyperspectral remote sensing and its application in vegetation and water resource studies", Water SA, 33(2): 145-151. (Cited on page 17.)

Graf, W.L. (1999), "Dam nation: A geographic census of American dams and their large-scale hydrologic impacts", Water Resources Research, 35(4): 1305-1311, [DOI]. (Cited on page 20.)

Gresswell, R.E., Torgersen, C.E., Bateman, D.S., Guy, T.J., Hendricks, S.R. and Wofford, J.E.B. (2006), "A spatially explicit approach for evaluating relationships among coastal cutthroat trout, habitat, and disturbance in headwater streams", in Hughes, R.M., Wang, L. and Seelbach, P., eds., Landscape Influences on Stream Habitats and Biological Assemblages, Proceedings of the Symposium held in Madison, Wisconsin, USA, 25-26 August 2004, AFS Symposium, 48, pp. 457-471, Bethesda, MD (American Fisheries Society). (Cited on page 19.)

Gurevitch, J. and Padilla, D.K. (2004), "Are invasive species a major cause of extinctions?", Trends in Ecology 86 Evolution, 19(9): 470-474, [DOI]. (Cited on page 28.)

Hall, R.K., Watkins, R.L., Heggem, D.T., Jones, K.B., Kaufmann, P.R., Moore, S.B. and Gregory, S.J. (2009), "Quantifying structural physical habitat attributes using LIDAR and hyperspectral imagery", Environmental Monitoring and Assessment, 159: 63-83, [DOI]. (Cited on pages 10 and 17.)

Living Reviews in Landscape Research

http://www. livingreviews . org/lrlr-2010-1 
Harding, J.S., Benfield, E.F., Bolstad, P.V., Helfman, G.S. and Jones III, E.B.D. (1998), "Stream biodiversity: The ghost of land use past", Proceedings of the National Academy of Sciences of the USA, 95: 14843-14847, [DOI]. (Cited on page 28.)

Hawkes, H.A. (1975), "River zonation and classification", in Whitton, B.A., ed., River Ecology, pp. 312-374, Berkeley and Los Angeles (University of California Press). Google Books. (Cited on page 19.)

Hawkins, C.P., Kershner, J.L., Bisson, P.A., Bryant, M.D., Decker, L.M., Gregory, S.V., McCullough, D.A., Overton, C.K., Reeves, G.H. and Steedman, R.J. (1993), "A hierarchical approach to classifying stream habitat features", Fisheries, 18(6): 3-12, [DOI]. (Cited on page 12.)

Hawkins, C.P., Norris, R.H., Gerritsen, J., Hughes, R.M., Jackson, S.K., Johnson, R.K. and Stevenson, R.J. (2000), "Evaluation of the use of landscape classifications for the prediction of freshwater biota: Synthesis and recommendations", Journal of the North American Benthological Society, 19(3): 541-556, [DOI]. (Cited on page 23.)

Herlihy, A.T., Hughes, R.M. and Sifneos, J.C. (2006), "Landscape clusters based on fish assemblages in the conterminous USA and their relationship to existing landscape classifications", in Hughes, R.M., Wang, L. and Seelbach, P.W., eds., Landscape Influences on Stream Habitats and Biological Assemblages, Proceedings of the Symposium held in Madison, Wisconsin, USA, 2526 August 2004, AFS Symposium, 48, pp. 87-112, Bethesda, MD (American Fisheries Society). (Cited on page 23.)

Hitt, N.P. and Angermeier, P.L. (2006), "Effects of adjacent streams on local fish assemblage structure in western Virginia: Implications for biomonitoring", in Hughes, R.M., Wang, L. and Seelbach, P.W., eds., Landscape Influences on Stream Habitats and Biological Assemblages, Proceedings of the Symposium held in Madison, Wisconsin, USA, 25-26 August 2004, AFS Symposium, 48, pp. 75-86, Bethesda, MD (American Fisheries Society). (Cited on pages 19 and 27.)

Hitt, N.P. and Angermeier, P.L. (2008a), "Evidence for fish dispersal from spatial analysis of stream network topology", Journal of the North American Benthological Society, 27: 304-320, [DOI]. (Cited on page 19.)

Hitt, N.P. and Angermeier, P.L. (2008b), "River-stream connectivity affects fish bioassessment performance", Environmental Management, 42(1): 132-150, [DOI]. (Cited on pages 19, 22, and 23.)

Hogan, D.M. and Walbridge, M.R. (2007), "Urbanization and nutrient retention in freshwater riparian wetlands", Ecological Applications, 17(4): 1142-55, [DOI]. (Cited on page 18.)

Holden, P.B., Deacon, J.E. and Golden, M.E. (2005), "Historical changes in fishes of the VirginMoapa River system: continuing decline of a unique native fauna", in Rinne, J.N., Hughes, R.M. and Calamusso, B., eds., Historical Changes in Large River Fish Assemblages of the Americas, Proceedings of the Symposium held in Phoenix, Arizona, USA, 21 August 2001, AFS Symposium, 45, pp. 99-114, Bethesda, MD (American Fisheries Society). (Cited on page 20.)

Hollenhorst, T.P., Brown, T.N., Johnson, L.B., Ciborowski, J.J.H. and Host, G.E. (2007), "Methods for generating muli-scale watershed delineations for indicator development in Great Lakes coastal ecosystems", Journal of Great Lakes Research, 33: 13-26, [DOI]. (Cited on page 26.)

Host, G.E., Schuldt, J., Ciborowski, J.J.H., Johnson, L.B., Hollenhorst, T. and Richards, C. (2005), "Use of GIS and remotely sensed data for a priori identification of reference areas for Great Lakes 
coastal ecosystems", International Journal of Remote Sensing, 26(23): 5325-41, [DOI]. (Cited on page 17.)

Houssain, N.A., Younis, K.H. and Yousif, U.H. (2001), "Evaluation of environmental degradation in the fish assemblage of Shatt Al-Arab River", Pakistan Journal of Zoology, 33(2): 93-98. (Cited on page 27.)

Hued, A.C. and Bistoni, M. (2003), "Development and validation of a biotic index for evaluation of environmental quality in the central region of Argentina", Hydrobiologia, 543: 279-298. (Cited on page 27.)

Huet, M. (1949), "Aperçu des relations entre la pente et les populations piscicoles des eaux courantes", Aquatic Sciences, 11: 332-351. (Cited on page 19.)

Hughes, F.M.R., Moss, T. and Richards, K.S. (2008), "Uncertainty in Riparian and Floodplain Restoration", in Darby, S. and Sear, D., eds., River Restoration: Managing the Uncertainty in Restoring Physical Habitat, pp. 79-104, Chichester (John Wiley \& Sons, Ltd.), [DOI]. (Cited on pages $6,7,9$, and 25.)

Hughes, J.M. (2007), "Constraints on Recovery: Using molecular methods to study connectivity of aquatic biota in rivers and streams", Freshwater Biology, 52(4): 616-631, [DOI]. (Cited on page 19.)

Hughes, M.L., McDowell, P.F. and Marcus, W.A. (2006a), "Accuracy assessment of georectified aerial photographs: Implications for measuring lateral channel movement in a GIS", Geomorphology, 74(1-4): 1-16, [DOI]. (Cited on page 25.)

Hughes, R.M., Paulsen, S.G. and Stoddard, J.L. (2000), "EMAP-Surface Waters: a national, multiassemblage, probability survey of ecological integrity", Hydrobiologia, 422/423: 429-443. (Cited on page 25.)

Hughes, R.M., Howlin, S. and Kaufmann, P.R. (2004), "A biointegrity index (IBI) for coldwater streams of western Oregon and Washington", Transactions of the American Fisheries Society, 133: 1497-1515, [DOI]. (Cited on page 27.)

Hughes, R.M., Rinne, J.N. and Calamusso, B. (2005a), "Introduction to historical changes in large river fish assemblages of the Americas", in Rinne, J.N., Hughes, R.M. and Calamusso, B., eds., Historical Changes in Large River Fish Assemblages of the Americas, Proceedings of the Symposium held in Phoenix, Arizona, USA, 21 August 2001, AFS Symposium, 45, pp. 1-12, Bethesda, MD (American Fisheries Society). (Cited on page 27.)

Hughes, R.M., Rinne, J.N. and Calamusso, B. (2005b), "Historical changes in large river fish assemblages of the Americas: A synthesis", in Rinne, J.N., Hughes, R.M. and Calamusso, B., eds., Historical Changes in Large River Fish Assemblages of the Americas, Proceedings of the Symposium held in Phoenix, Arizona, USA, 21 August 2001, AFS Symposium, 45, pp. 603-612, Bethesda, MD (American Fisheries Society). (Cited on page 20.)

Hughes, R.M., Wang, L. and Seelbach, P.W., eds. (2006b), Landscape Influences on Stream Habitats and Biological Assemblages, Proceedings of the Symposium held in Madison, Wisconsin, USA, 25-26 August 2004, AFS Symposium, 48, Bethesda, MD (American Fisheries Society). (Cited on page 13.)

Hugueny, B., Camara, S., Smoura, B. and Magassouba, M. (1996), "Applying an index of biotic integrity based on fish communities in a west African river", Hydrobiologia, 331: 71-78, [DOI]. (Cited on page 27.)

Living Reviews in Landscape Research

http://www. livingreviews . org/lrlr-2010-1 
Hulse, D.W., Branscomb, A. and Payne, S.G. (2004), "Envisioning alternatives: Using citizen guidance to map future land and water use", Ecological Applications, 14(2): 325-341, [DOI]. (Cited on page 24.)

Humphries, P. and Winemiller, K.O. (2009), "Historical impacts on river fauna, shifting baselines, and challenges for restoration", BioScience, 59: 673-684, [DOI]. (Cited on page 28.)

Hunsaker, C.T. and Hughes, R.M. (2002), "Effects of Landscape Change on the Physical and Chemical Components of Aquatic Ecosystems", in Gutzwiller, K.J., ed., Applying Landscape Ecology in Biological Conservation, pp. 286-308, New York; Berlin (Springer). Google Books. (Cited on page 30.)

Hynes, H.B.N. (1975), "The stream and its valley", in Proceedings of the 19th Congress of the International Association of Theoretical and Applied Limnology, Winnipeg, Canada, August 1974, Verhandlungen IVL, 19, pp. 1-15, Stuttgart (Schweizerbart). (Cited on pages 5, 10, and 12.)

Ibañez, C., Belliard, J., Hughes, R.M., Irz, P., Kamdem-Toham, A., Lamouroux, N. and Oberdorff, T. (2009), "Convergence of temperate and tropical stream fish assemblages", Ecography, 32(4): 658-670. (Cited on page 19.)

Independent Multidisciplinary Science Team (2007), "Considerations for the Use of Ecological Indicators in Restoration Effectiveness Evaluation", IMST Technical Report, 2007-1, Salem, OR (Oregon Watershed Enhancement Board). Online version (accessed 21 May 2010): http://www.fsl.orst.edu/imst/reports/monitoring.html. (Cited on page 6.)

Independent Multidisciplinary Science Team (2009), "Issues in the Aggregation of Data to Assess Environmental Conditions", IMST Technical Report, 2009-1, Salem, OR (Oregon Watershed Enhancement Board). Online version (accessed 21 May 2010):

http://www.fsl.orst.edu/imst/reports/monitoring.html. (Cited on pages 17 and 25.)

Independent Multidisciplinary Science Team (2010), "Urban and Rural Residential Land Uses: Their Role in Watershed Health and the Rehabilitation of Oregon's Wild Salmonids", IMST Technical Report, 2010-1, Salem, OR (Oregon Watershed Enhancement Board). Online version (accessed 21 May 2010):

http://www.fsl.orst.edu/imst/reports.html. (Cited on page 18.)

Ioannidis, J.P.A. (2005), "Why most published research findings are false", PLoS Medicine, 2(8), e124, [DOI]. (Cited on page 25.)

Isaak, D.J., Thurow, R.F., Rieman, B.E. and Dunham, J.B. (2007), "Chinook salmon use of spawning patches: relative roles of habitat quality, size, and connectivity", Ecological Applications, 17 (2): 352-364, [DOI]. (Cited on pages 18 and 19.)

Jansson, R., Nilsson, C. and Malmqvist, B. (2007), "Restoring freshwater ecosystems in riverine landscapes: the roles of connectivity and recovery processes", Freshwater Biology, 52(4): 589596, [DOI]. (Cited on page 23.)

Jenerette, G.D. and Wu, J. (2000), "On the definitions of scale", Bulletin of the Ecological Society of America, 81(1): 104-105. (Cited on page 18.)

Johnson, L. and Gage, S. (1997), "Landscape approaches to the analysis of aquatic ecosystems", Freshwater Biology, 37(1): 113-132, [DOI]. (Cited on pages 9, 12, 26, and 28.)

Johnson, L.B. and Host, G.E (2010), "Recent developments in landscape approaches for the study of aquatic ecosystems", Journal of the North American Benthological Society, 29: 41-66, [DOI]. (Cited on pages 9, 13, and 19.) 
Jones, K.L., Poole, G.C., O’Daniel, S.J., Mertes, L.A.K. and Stanford, J.A. (2008), "Surface hydrology of low-relief landscapes: Assessing surface water flow impedance using LIDAR-derived digital elevation models", Remote Sensing of Environment, 112(11): 4148-4159, [DOI]. (Cited on page 10.)

Jorgensen, J.C., Honea, J.M., McClure, M.M., Cooney, T.D., Engie, K. and Holzer, D.M. (2009), "Linking landscape-level change to habitat quality: an evaluation of restoration actions on the freshwater habitat of spring-run Chinook salmon", Freshwater Biology, 54: 1560-1575, [DOI]. (Cited on page 29.)

Joy, M.K. and Death, R.G. (2004), "Application of the index of biotic integrity methodology to New Zealand freshwater fish communities", Environmental Management, 34: 415-428, [DOI]. (Cited on pages 23 and 27.)

Kail, J., Hering, D., Muhar, S., Gerhard, M. and Preis, S. (2007), "The use of large wood in stream restoration: experiences from 50 projects in Germany and Austria", Journal of Applied Ecology, 44: 1145-1155, [DOI]. (Cited on page 25.)

Kearns, F.R., Kelly, N.M., Carter, J.L. and Resh, V.H. (2005), "A method for the use of landscape metrics in freshwater research and management", Landscape Ecology, 20(1): 113-125, [DOI]. (Cited on page 30.)

Kershner, J.L., Roper, B.B., Bouwes, N., Henderson, R. and Archer, E. (2004), "An analysis of stream habitat conditions in reference and managed watersheds on some federal lands within the Columbia River Basin", North American Journal of Fisheries Management, 24(4): 1363-75, [DOI]. (Cited on pages 18 and 21.)

King, R.S., Baker, M.E., Whigham, D.F., Weller, D.E., Jordan, T.E., Kazyak, P.F. and Hurd, M.K. (2005), "Spatial considerations for linking watershed land cover to ecological indicators in streams", Ecological Applications, 15(1): 137-153, [DOI]. (Cited on pages 28 and 30.)

Kinzel, P.J. (2009), "Advanced tools for river science: EAARL and MD_SWMS", in Bayer, J.M. and Schei, J.L., eds., PNAMP Special Publication: Remote Sensing Applications for Aquatic Resource Monitoring: Pacific Northwest Aquatic Monitoring Partnership, PNAMP Special Session at the 2008 ASPRS Annual Meeting, pp. 17-26, Cook, WA (Pacific Northwest Aquatic Monitoring Partnership). URL (accessed 5 March 2010):

http://www.pnamp.org/node/2550. (Cited on page 10.)

Kinzel, P.J., Wright, C.W., Nelson, J.M. and Burman, A.R. (2007), "Evaluation of an experimental LiDAR for surveying a shallow, braided, sand-bedded river", Journal of Hydraulic Engineering, 133(7): 838-842, [DOI]. (Cited on page 17.)

Klauda, R., Kazyak, P., Stranko, S., Southerland, M., Roth, N. and Chaillou, J. (1998), "Maryland biological stream survey: A state agency program to assess the impact of anthropogenic stresses on stream habitat quality and biota", Environmental Monitoring and Assessment, 51: 299-316, [DOI]. (Cited on page 27.)

Kleynhans, C.J. (1999), "The development of a fish index to assess the biological integrity of South African rivers", Water SA, 25(3): 265-278. (Cited on pages 9 and 27.)

Kracker, L. (2006), "Disconnected rivers", Landscape Ecology, 21(1): 153-154, [DOI]. (Cited on page 22.)

Lake, P.S., Bond, N. and Reich, P. (2007), "Linking ecological theory with stream restoration", Freshwater Biology, 52: 597-615, [DOI]. (Cited on page 23.) 
Lammert, M. and Allan, J.D. (1999), "Assessing biotic integrity of streams: Effects of scale in measuring the influence of land use/cover and habitat structure on fish and macroinvertebrates", Environmental Management, 23(2): 257-270, [DOI]. (Cited on page 19.)

LaVigne, H.R., Hughes, R.M. and Herlihy, A.T. (2008a), "Bioassessments to detect changes in Pacific Northwest river fish assemblages: a Malheur River case study", Northwest Science, 82: 251-258, [DOI]. (Cited on pages 20 and 27.)

LaVigne, H.R., Hughes, R.M., Wildman, R.C., Gregory, S.V. and Herlihy, A.T. (2008b), "Summer distribution and species richness of non-native fishes in the mainstem Willamette River, Oregon, 1944-2006", Northwest Science, 82: 83-93, [DOI]. (Cited on page 27.)

Leckie, D.G., Cloney, E., Jay, C. and Paradine, D. (2005), "Automated mapping of stream features with high-resolution multispectral imagery: An example of the capabilities", Photogrammetric Engineering $\&$ Remote Sensing, 71(2): 145-155. (Cited on pages 16 and 17.)

Leclerc, J. and DesGranges, J.L. (2005), "Exploratory multiscale analysis of the fish assemblages and habitats of the Lower St. Lawrence River, Québec, Canada", Biodiversity and Conservation, 14(5): 1153-1174, [DOI]. (Cited on page 19.)

Legleiter, C.J. (2003), "Spectrally driven classification of high spatial resolution, hyperspectral imagery: A tool for mapping in-stream habitat", Environmental Management, 32(3): 399-411, [DOI]. (Cited on pages 10 and 16.)

Legleiter, C.J. and Roberts, D.A. (2005), "Effects of channel morphology and sensor spatial resolution on image-derived depth estimates", Remote Sensing of Environment, 95(2): 231-247, [DOI]. (Cited on page 16.)

Legleiter, C.J., Marcus, W.A. and Lawrence, R.L. (2002), "Effects of sensor resolution on mapping in-stream habitats", Photogrammetric Engineering 86 Remote Sensing, 68(8): 801-807. (Cited on page 10.)

Legleiter, C.J., Roberts, D.A., Marcus, W.A. and Fonstad, M.A. (2004), "Passive optical remote sensing of river channel morphology and in-stream habitat: Physical basis and feasibility", Remote Sensing of Environment, 93(4): 493-510, [DOI]. (Cited on page 16.)

Lehmann, A. and Lachavanne, J.-B. (1997), "Geographic information systems and remote sensing in aquatic botany", Aquatic Botany, 58(3-4): 195-207, [DOI]. (Cited on page 17.)

Lelek, A. (1989), "The Rhine river and some of its tributaries under human impact in the last two centuries", in Dodge, D.P., ed., Proceedings of the International Large River Symposium (LARS), Honey Harbour, Ontario, Canada, September 14-21, 1986, Canadian Special Publication of Fisheries and Aquatic Sciences, 106, pp. 469-487, Ottawa (Fisheries and Oceans Canada). (Cited on page 20.)

Leprieur, F., Beauchard, O., Blanchet, S., Oberdorff, T. and Brosse, S. (2008a), "Fish invasions in the world's river systems: When natural processes are blurred by human activities", PLoS Biology, 6(2), e28, [DOI]. (Cited on pages 21 and 23.)

Leprieur, F., Beauchard, O., Hugueny, B., Grenouillet, G. and Brosse, S. (2008b), "Null model of biotic homogenization: A test with the European freshwater fish fauna", Diversity and Distributions, 14(2): 291-300, [DOI]. (Cited on pages 9, 21, and 27.)

Letcher, B.H., Nislow, K.H., Coombs, J.A., O’Donnell, M.J. and Dubreuil, T.L. (2007), "Population response to habitat fragmentation in a stream-dwelling brook trout population", $P L o S$ ONE, 2(11), e1139, [DOI]. (Cited on page 20.) 
Leuven, R.S.E.W., Poudevigne, I. and Teeuw, R.M., eds. (2002), Application of Geographic Information Systems and Remote Sensing in River Studies, Contains updated lectures of a European Socrates workshop organized by the Department of Environmental Studies of the University of Nijmegen on September 7-8, 1998, Leiden (Backhuys Publishers). (Cited on page 10.)

Levin, S.A. (1992), "The problem of pattern and scale in ecology: The Robert H. MacArthur Award Lecture", Ecology, 73(6): 1943-1967, [DOI]. (Cited on page 18.)

Li, H.W., Currens, K., Bottom, D., Clarke, S., Dambacher, J., Frissell, C., Harris, P., Hughes, R.M., McCullough, D., McGie, A., Moore, K., Nawa, R. and Thiele, S. (1996), "Safe havens: refuges and evolutionarily significant units", in Nielson, J.L., ed., Evolution and the Aquatic Ecosystem: Defining Unique Units in Population Conservation, Proceedings of the Symposium held at Monterey, California, USA, 23-25 May 1994, AFS Symposium, 17, pp. 371-380, Bethesda, MD (American Fisheries Society). (Cited on page 22.)

Light, T. and Marchetti, M.P. (2007), "Distinguishing between invasions and habitat changes as drivers of diversity loss among California's freshwater fishes", Conservation Biology, 21(2): 434-446, [DOI]. (Cited on page 28.)

Lisboa, A.H., Goulart, E.M.A. and Diniz, L.F.M. (2008), Projeto Manuelzão: a história da mobilização que começou em torno de um rio, Belo Horizonte (Instituto Guaicuy). (Cited on page 9.)

Lomnicky, G.A., Whittier, T.R., Hughes, R.M. and Peck, D.V. (2007), "Distribution of nonnative aquatic vertebrates in western US streams and rivers", North American Journal of Fisheries Management, 27(4): 1082-93, [DOI]. (Cited on page 9.)

Lorang, M.S., Whited, D.C., Hauer, F.R., Kimball, J.S. and Stanford, J.A. (2005), "Using airborne multispectral imagery to evaluate geomorphic work across floodplains of gravel-bed rivers", Ecological Applications, 15(4): 1209-22, [DOI]. (Cited on page 16.)

Lowe, W.H., Likens, G.E. and Power, M.E. (2006), "Linking scales in stream ecology", BioScience, 56(7): 591-597, [DOI]. (Cited on page 19.)

Madriñán, L.F. (2008), Biophysical Factors Driving the Distribution and Abundance of Redband/Steelhead Trout (Oncorhynchus mykiss gairdneri) in the South Fork John Day River Basin, Oregon, USA, Ph.D. Thesis, Oregon State University, Corvallis, OR. URL (accessed 9 April 2010):

http://hdl.handle.net/1957/8368. (Cited on page 17.)

Malmqvist, B. (2002), "Aquatic invertebrates in riverine landscapes", Freshwater Biology, 47: 679-694, [DOI]. (Cited on page 12.)

Marcus, W.A. (2002), "Mapping of stream microhabitats with high spatial resolution hyperspectral imagery", Journal of Geographical Systems, 4(1): 113-126, [DOI]. (Cited on page 10.)

Marcus, W.A. and Fonstad, M.A. (2007), "Optical remote mapping of rivers at sub-meter resolutions and watershed extents", Earth Surface Processes and Landforms, 33(1): 4-24, [DOI]. (Cited on page 17.)

Marcus, W.A., Legleiter, C.J., Aspinall, R.J., Boardman, J.W. and Crabtree, R.L. (2003), "High spatial resolution hyperspectral mapping of in-stream habitats, depths, and woody debris in mountain streams", Geomorphology, 55(1-4): 363-380, [DOI]. (Cited on page 16.)

Living Reviews in Landscape Research

http: //www. livingreviews . org/lrlr-2010-1 
Margules, C.R. and Pressey, R.L. (2000), "Systematic conservation planning", Nature, 405(6783): 243-253, [DOI]. (Cited on page 21.)

Marsh-Matthews, E. and Matthews, W.J. (2000), "Geographic, terrestrial and aquatic factors: which most influence the structure of stream fish assemblages in the midwestern United States?", Ecology of Freshwater Fish, 9: 9-21, [DOI]. (Cited on page 19.)

Mattson, K.M. and Angermeier, P.L. (2007), "Integrating human impacts and ecological integrity into a risk-based protocol for conservation planning", Environmental Management, 39(1): 125138, [DOI]. (Cited on page 22.)

Matulla, C., Schmutz, S., Melcher, A., Gerersdorfer, T. and Haas, P. (2007), "Assessing the impact of a downscaled climate change simulation on the fish fauna in an inner-Alpine river", International Journal of Biometeorology, 52(2): 127-137, [DOI]. (Cited on pages 24 and 27.)

McCormick, F.H., Hughes, R.M., Kaufmann, P.R., Herlihy, A.T. and Peck, D.V. (2001), "Development of an index of biotic integrity for the mid-Atlantic highlands region", Transactions of the American Fisheries Society, 130: 857-877, [DOI]. (Cited on page 27.)

McGarvey, D.J. and Hughes, R.M. (2008), "Longitudinal zonation of Pacific Northwest (U.S.A.) fish assemblages and the species-discharge relationship", Copeia, 2008: 311-321, [DOI]. (Cited on page 19.)

McKean, J., Isaak, D. and Wright, W. (2009a), "Improving stream studies with a small-footprint green Lidar", Eos Trans. AGU, 90(39): 341-342, [DOI]. (Cited on page 17.)

McKean, J., Nagel, D., Tonina, D., Bailey, P., Wright, C.W., Bohn, C. and Nayegandhi, A. (2009b), "Remote sensing of channels and riparian zones with a narrow-beam aquatic-terrestrial LIDAR", Remote Sensing, 1: 1065-1096, [DOI]. URL (accessed 5 March 2010): http://www.mdpi.com/2072-4292/1/4/1065. (Cited on page 17.)

McKean, J.A., Isaak, D.J. and Wright, C.W. (2008), "Geomorphic controls on salmon nesting patterns described by a new, narrow-beam terrestrial-aquatic lidar", Frontiers in Ecology and the Environment, 6(3): 125-130, [DOI]. (Cited on pages 10 and 17.)

Meffe, G.K. (1984), "Effects of abiotic disturbance on coexistence of predator-prey fish species", Ecology, 65: 1525-1534, [DOI]. (Cited on page 20.)

Mertes, L.A.K. (2002), "Remote sensing of riverine landscapes", Freshwater Biology, 47(4): 799816, [DOI]. (Cited on pages 10 and 12.)

Miller Reed, K. and Czech, B. (2005), "Causes of fish endangerment in the United States, or the structure of the American economy", Fisheries, 30(7): 36-38. (Cited on pages 9 and 21.)

Miltner, R.J., White, D. and Yoder, C. (2004), "The biotic integrity of streams in urban and suburbanizing landscapes", Landscape and Urban Planning, 69(1): 87-100, [DOI]. (Cited on page 22.)

Moerke, A.H. and Lamberti, G.A. (2006), "Relationships between land use and stream ecosystems: A multistream assessment in southwestern Michigan", in Hughes, R.M., Wang, L. and Seelbach, P.W., eds., Landscape Influences on Stream Habitats and Biological Assemblages, Proceedings of the Symposium held in Madison, Wisconsin, USA, 25-26 August 2004, AFS Symposium, 48, pp. 323-338, Bethesda, MD (American Fisheries Society). (Cited on page 19.)

Morley, S.A. and Karr, J.R. (2002), "Assessing and restoring the health of urban streams in the Puget Sound Basin", Conservation Biology, 16(6): 1498-509, [DOI]. (Cited on page 22.) 
Moss, T.H. (2004), "The governance of land use in river basins: prospects for overcoming problems of institutional interplay with the EU Water Framework Directive", Land Use Policy, 21(1): 85, [DOI]. (Cited on page 8.)

Mouton, A. (2005), Generating Stream Maps Using LiDAR Derived Digital Elevation Models and 10-m USGS DEM, Master's Thesis, University of Washington, Seattle. Online version (accessed 21 October 2009):

http://www.ruraltech.org/pubs/theses/mouton/. (Cited on page 10.)

Mugodo, J., Kennard, M., Liston, P., Nichols, S., Linke, S., Norris, R.H. and Lintermans, M. (2006), "Local stream habitat variables predicted from catchment scale characteristics are useful for predicting fish distribution", Hydrobiologia, 572: 59-70, [DOI]. (Cited on page 19.)

Murray, K. (1999), "National Aquatic Ecosystem Biomonitoring Programme: National Implementation Assessment", NAEBP Report Series, No. 8, Pretoria, South Africa (Institute for Water Quality Studies, Department of Water Affairs and Forestry). (Cited on page 9.)

Naidoo, R. and Adamowicz, W.L. (2001), "Effects of economic prosperity on numbers of threatened species", Conservation Biology, 15(4): 1021-1029, [DOI]. (Cited on page 21.)

Naiman, R.J., Beechie, T.J., Benda, L.E., Berg, D.R., Bisson, P.A., MacDonald, L.H., O’Connor, W.D., Olson, P.L. and Steel, E.A. (1992), "Fundamental elements of ecologically healthy watersheds in the Pacific Northwest coastal ecoregion", in Naiman, R.J., ed., Watershed Management: Balancing Sustainability and Environmental Change, Symposium held in Seattle, Washington, USA, on New Perspectives for Watershed Management in the Pacific Northwest, November 27 -29, 1990, pp. 127-188. Google Books, New York (Springer). (Cited on page 5.)

Nelson, S.A.C., Cheruvelil, K.S. and Soranno, P.A. (2006), "Satellite remote sensing of freshwater macrophytes and the influence of water clarity", Aquatic Botany, 85(4): 289-298, [DOI]. (Cited on page 17.)

Nerbonne, B.A. and Vondracek, B. (2001), "Effects of local land use on physical habitat, benthic macroinvertebrates, and fish in the Whitewater River, Minnesota, USA", Environmental Management, 28(1): 87-99, [DOI]. (Cited on page 22.)

Nilsson, C., Reidy, C.A., Dynesius, M. and Ravenga, C. (2005), "Fragmentation and flow regulation of the world's large river systems", Science, 308: 405-408, [DOI]. (Cited on page 27.)

Oberdorff, T. and Hughes, R.M. (1992), "Modification of an index of biotic integrity based on fish assemblages to characterize rivers of the Seine Basin, France", Hydrobiologia, 228: 117-130, [DOI]. (Cited on page 20.)

Ode, P.R., Rehn, A.C. and May, J.T. (2005), "A quantitative tool for assessing the integrity of southern coastal California streams", Environmental Management, 35: 493-504, [DOI]. (Cited on page 27.)

Olden, J.D. (2007), "Critical threshold effects of benthiscape structure on stream herbivore movement", Philosophical Transactions of the Royal Society of London, Series B, 362(1479): 461-472, [DOI]. (Cited on page 19.)

Osborne, L.L. and Wiley, M.J. (1992), "Influence of tributary spatial position on the structure of warmwater fish communities", Canadian Journal of Fisheries and Aquatic Sciences, 49: 671681, [DOI]. (Cited on pages 22 and 27.)

Living Reviews in Landscape Research

http://www. livingreviews.org/lrlr-2010-1 
Otte, A., Simmering, D. and Wolters, V. (2007), "Biodiversity at the landscape level: Recent concepts and perspectives for multifunctional land use", Landscape Ecology, 22(5): 639-642, [DOI]. (Cited on page 21.)

Palmer, M.A. and Bernhardt, E.S. (2006), "Hydroecology and river restoration: ripe for research and synthesis", Water Resources Research, 42, W03S07, [DOI]. (Cited on page 25.)

Park, Y.S., Chang, J.B., Lek, S., Cao, W.X. and Brosse, S. (2003), "Conservation strategies for endemic fish species threatened by the Three Gorges Dam", Conservation Biology, 17(6): 17481758, [DOI]. (Cited on page 20.)

Paul, M.J. and Meyer, J.L. (2001), "Streams in the urban landscape", Annual Review of Ecology and Systematics, 32: 333-365, [DOI]. (Cited on pages 18 and 21.)

Paulsen, C.M. and Fisher, T.R. (2001), "Statistical relationship between parr-to-smolt survival of Snake River spring-summer Chinook salmon and indices of land use", Transactions of the American Fisheries Society, 130(3): 347-358, [DOI]. (Cited on pages 18 and 21.)

Paulsen, S.G., Mayio, A., Peck, D.V., Stoddard, J.L., Tarquinio, E., Holdsworth, S.M., Van Sickle, J., Yuan, L.L., Hawkins, C.P., Herlihy, A.T., Kaufmann, P.R., Barbour, M.T., Larsen, D.P. and Olsen, A.R. (2008), "Condition of stream ecosystems in the US: an overview of the first national assessment", Journal of the North American Benthological Society, 27: 812-821, [DOI]. (Cited on pages $6,8,25$, and 27 .)

Pess, G.R., Montgomery, D.R., Steel, E.A., Bilby, R.E., Feist, B.E. and Greenberg, H.M. (2002), "Landscape characteristics, land use, and coho salmon (Oncorhynchus kisutch) abundance Snohomish River, Wash., USA", Canadian Journal of Fisheries and Aquatic Sciences, 59: 613-623, [DOI]. (Cited on page 18.)

Peters, J., de Baets, B., Verhoest, N.E.K., Samson, R., Degroeve, S., de Becker, P. and Huybrechts, W. (2007), "Random forests as a tool for ecohydrological distribution modeling", Ecological Modelling, 207: 304-318, [DOI]. (Cited on page 29.)

Peterson, G.D., Cumming, G.S. and Carpenter, S.R. (2003), "Scenario planning: A tool for conservation in an uncertain world", Conservation Biology, 17(2): 358-366, [DOI]. (Cited on page 29.)

Pickett, S.T.A. and White, P.S., eds. (1985), The Ecology of Natural Disturbance and Patch Dynamics, London (Academic Press). (Cited on page 29.)

Pinto, B.C.T., Araujo, F.G. and Hughes, R.M. (2006), "Effects of landscape and riparian condition on a fish index of biotic integrity in a large southeastern Brazil river", Hydrobiologia, 556: 69-83, [DOI]. (Cited on pages 23, 26, and 27.)

Pinto, B.C.T., Araujo, F.G., Rodrigues, V.D. and Hughes, R.M. (2009), "Local and ecoregion effects on fish assemblage structure in tributaries of the Rio Paraíba do Sul, Brazil", Freshwater Biology, 54(12): 2600-2615, [DOI]. (Cited on page 23.)

Poff, N.L. (1997), "Landscape filters and species traits: Towards mechanistic understanding and prediction in stream ecology", Journal of the North American Benthological Society, 16(2): 391409, [DOI]. (Cited on page 12.)

Poissant, J., Knight, T.W. and Ferguson, M.M. (2005), "Nonequilibrium conditions following landscape rearrangement: the relative contribution of past and current hydrological landscapes on the genetic structure of a stream-dwelling fish", Molecular Ecology, 14: 1321-1331, [DOI]. (Cited on page 28.) 
Pont, D., Hugueny, B., Beier, U., Goffaux, D., Melcher, A., Noble, R., Rogers, C., Roset, N. and Schmutz, S. (2006), "Assessing river biotic condition at a continental scale: a European approach using functional metrics and fish assemblages", Journal of Applied Ecology, 43: 70-80, [DOI]. (Cited on pages 6 and 25.)

Pont, D., Hughes, R.M., Whittier, T.R. and Schmutz, S. (2009), "A predictive index of biotic integrity model for aquatic-vertebrate assemblages of western U.S. streams", Transactions of the American Fisheries Society, 138: 292-305, [DOI]. (Cited on page 6.)

Poole, G.C. (2002), "Fluvial landscape ecology: addressing uniqueness within the river discontinuum", Freshwater Biology, 47(4): 641-660, [DOI]. (Cited on page 12.)

Poole, G.C. (2010), "Stream hydrogeomorphology as a physical science basis for advances in stream ecology", Journal of the North American Benthological Society, 29: 12-25, [DOI]. (Cited on page 13.)

Poudevigne, I., Alard, D., Leuven, R.S.E.W. and Nienhuis, P.H. (2002), "A systems approach to river restoration: a case study in the lower Seine valley, France", River Research and Applications, 18: 239-247, [DOI]. (Cited on page 13.)

Pringle, C.M. (1997), "Exploring how disturbance is transmitted upstream: Going against the flow", Journal of the North American Benthological Society, 16(2): 425-438, [DOI]. (Cited on page 27.)

Pyne, M.I., Rader, R.B. and Christensen, W.F. (2007), "Predicting local biological characteristics in streams: A comparison of landscape classifications", Freshwater Biology, 52: 1302-1321, [DOI]. (Cited on page 28.)

Randhir, T.O. and Ekness, P. (2009), "Urbanization effects on watershed habitat potential: A multivariate assessment of thresholds and interactions", Ecohydrology, 2(1): 88-101, [DOI]. (Cited on page 21.)

Randhir, T.O. and Hawes, A.G. (2009), "Watershed land use and aquatic ecosystem response: Ecohydrologic approach to conservation policy", Journal of Hydrology, 364: 182-199, [DOI]. (Cited on page 24.)

Randhir, T.O. and Tsvetkova, O. (2009), "Watershed-Scale tradeoffs in water quantity and quality attributes for conservation policy", Water, Air, ES Soil Pollution, 201: 347-363, [DOI]. (Cited on page 21.)

Reynolds, K. and Peets, S. (2001), "Integrated assessment and priorities for protection and restoration of watersheds", in Forest Biometry, Modelling and Information Science, Proceedings of a IUFRO 4.11 conference held at the University of Greenwich, June 2001, London (University of Greenwich). URL (accessed 21 October 2009):

http://cms1.gre.ac.uk/conferences/iufro/proceedings/ReynoldsNew.pdf. (Cited on page 24 .)

Reynolds, K.M. and Hessburg, P.F. (2005), "Decision support for integrated landscape evaluation and restoration planning", Forest Ecology and Management, 207(1-2): 263-278, [DOI]. (Cited on page 24.)

Richards, C., Johnson, L.B. and Host, G.E. (1996), "Landscape-scale influences on stream habitats and biota", Canadian Journal of Fisheries and Aquatic Sciences, 53(S1): 295-311, [DOI]. (Cited on pages 18 and 19.)

Living Reviews in Landscape Research

http: //www. livingreviews . org/lrlr-2010-1 
Richards, C., Haro, R.J., Johnson, L.B. and Host, G.E. (1997), "Catchment and reach-scale properties as indicators of microinvertebrate species traits", Freshwater Biology, 37: 219-230, [DOI]. (Cited on page 12.)

Rieman, B., Peterson, J.T., Clayton, J., Howell, P., Thurow, R., Thompson, W. and Lee, D. (2001), "Evaluation of potential effects of federal land management alternatives on trends of salmonids and their habitats in the interior Columbia River basin", Forest Ecology and Management, 153: 43-62, [DOI]. (Cited on page 24.)

Rieman, B.E., Isaak, D., Adams, S., Horan, D., Nagel, D., Luce, C. and Myers, D. (2007), "Anticipated climate warming effects on bull trout habitats and populations across the interior Columbia River basin", Transactions of the American Fisheries Society, 136(6): 1552-65, [DOI]. (Cited on pages 21 and 24.)

Rinne, J.N., Hughes, R.M. and Calamusso, B., eds. (2005), Historical Changes in Large River Fish Assemblages of the Americas, Proceedings of the Symposium held in Phoenix, Arizona, USA, 21 August 2001, AFS Symposium, 45, Bethesda, MD (American Fisheries Society). (Cited on page 27.)

Roni, P., Beechie, T.J., Bilby, R.E., Leonetti, F.E., Pollock, M.M. and Pess, G.R. (2002), "A review of stream restoration techniques and a hierarchical strategy for prioritizing restoration in Pacific Northwest watersheds", North American Journal of Fisheries Management, 22: 1-20, [DOI]. (Cited on page 25.)

Roni, P., Hanson, K. and Beechie, T.J. (2008), "Global review of the physical and biological effectiveness of stream habitat rehabilitation techniques", North American Journal of Fisheries Management, 28: 856-890, [DOI]. (Cited on page 24.)

Roper, B.B., Buffington, J.M., Bennett, S., Lanigan, S.H., Archer, E., Downie, S.T., Faustini, J., Hillman, T.W., Hubler, S., Jones, K., Jordan, C., Kaufmann, P.R., Merritt, G., Moyer, C. and Pleus, A. (2010), "A comparison of the performance and compatability of protocols used by seven monitoring groups to measure stream habitat in the Pacific Northwest", North American Journal of Fisheries Management, 30: 565-587. (Cited on page 17.)

Rose, C.A. (2005), "Economic growth as a threat to fish conservation in Canada", Fisheries, 30 (8): 36-38. (Cited on page 21.)

Roth, N.E., Allan, J.D. and Erickson, D.L. (1996), "Landscape influences on stream biotic integrity assessed at multiple spatial scales", Landscape Ecology, 11(3): 141-156, [DOI]. (Cited on pages $18,19,21$, and 22.)

Sanderson, B.L., Barnas, K.A. and Rub, M.W. (2009), "Nonindigenous species of the Pacific Northwest: An overlooked risk to endangered salmon?", BioScience, 59: 245-256, [DOI]. (Cited on page 9.)

Santoul, F., Figuerola, J., Mastrorillo, S. and Céréghino, R. (2005), "Patterns of rare fish and aquatic insects in a southwestern French river catchment in relation to simple physical variables", Ecography, 28(3): 307-314, [DOI]. (Cited on page 19.)

Sawaya, K.E., Olmanson, L.G., Heinert, N.J., Brezonik, P.L. and Bauer, M.E. (2003), "Extending satellite remote sensing to local scales: land and water resource monitoring using high-resolution imagery", Remote Sensing of Environment, 88(1-2): 144-156, [DOI]. (Cited on page 10.)

Schick, R.S. and Lindley, S.T. (2007), "Directed connectivity among fish populations in a riverine network", Journal of Applied Ecology, 44(6): 1116-26, [DOI]. (Cited on page 29.) 
Schleiger, S.L. (2000), "Use of an index of biotic integrity to detect effects of land uses on stream fish communities in west-central Georgia", Transactions of the American Fisheries Society, 129 (5): 1118-1133, [DOI]. (Cited on page 23.)

Schlosser, I.J. (1991), "Stream fish ecology: A landscape perspective", BioScience, 41(10): 704712, [DOI]. (Cited on pages 10 and 12.)

Schmutz, S. and Jungwirth, M. (2001), "Fish as indicators for connectivity in running water ecosystems", in Williams, W.D., ed., Proceedings of the 27th Congress of the International Association of Theoretical and Applied Limnology, Dublin, 1998, Verhandlungen IVL, 27, pp. 3971-3974, Stuttgart (Schweizerbart). (Cited on page 19.)

Schmutz, S., Melcher, A., Muhar, S., Zitek, A., Poppe, M., Trautwein, C. and Jungwirth, M. (2007), "MIRR - Model-based Instrument for River Restoration. Entwicklung eines strategischen Instruments zur integrativen Bewertung ökologischer Restaurationsmaßnahmen an Fließgewässern", Österreichische Wasser- und Abfallwirtschaft, 60(5-6): 95-103, [DOI]. (Cited on pages 24 and 26.)

Schneider, D.C. (2001), "The rise of the concept of scale in ecology", BioScience, 51(7): 545-553, [DOI]. (Cited on page 18.)

Scott, M.C. (2006), "Winners and losers among stream fishes in relation to land use legacies and urban development in the southeastern US", Biological Conservation, 127(3): 301-309, [DOI]. (Cited on pages 22 and 30.)

Shapiro, M.H., Holdsworth, S.M. and Paulsen, S.G. (2008), "The need to assess the condition of aquatic resources in the US", Journal of the North American Benthological Society, 27(4): 808-811, [DOI]. (Cited on pages 8 and 25.)

Sheer, M.B. and Steel, E.A. (2006), "Lost watersheds: Barriers, aquatic habitat connectivity, and species persistence in the Willamette and Lower Columbia basins", Transactions of the American Fisheries Society, 135: 1654-1669, [DOI]. (Cited on pages 20 and 23.)

Shriver, D.M. and Randhir, T.O. (2006), "Integrating stakeholder values with multiple attributes to quantify watershed performance", Water Resources Research, 42(8): 1-15, W08435, [DOI]. (Cited on page 24.)

Silva, T.S.F., Costa, M.P.F., Melack, J.M. and Novo, E. (2008), "Remote sensing of aquatic vegetation: Theory and applications", Environmental Monitoring and Assessment, 140(1): 131145, [DOI]. (Cited on pages 10 and 17.)

Smikrud, K.M. and Prakash, A. (2006), "Monitoring large woody debris dynamics in the Unuk River, Alaska using digital aerial photography", GIScience \&6 Remote Sensing, 43(2): 142-154. (Cited on page 10.)

Smikrud, K.M., Prakash, A. and Nichols, J.V. (2008), "Decision-based fusion for improved fluvial landscape classification using digital aerial photographs and forward looking infrared images", Photogrammetric Engineering 6 Remote Sensing, 74: 903-911. (Cited on page 10.)

Snyder, C.D., Young, J.A., Villella, R. and Lemarie, D.P. (2003), "Influences of upland and riparian land use patterns on stream biotic integrity", Landscape Ecology, 18(7): 647-664, [DOI]. (Cited on pages 18 and 22.)

Soulsby, C., Youngson, A.F., Moir, H.J. and Malcolm, I.A. (2001), "Fine sediment influence on salmonid spawning habitat in a lowland agricultural stream: A preliminary assessment", Science of the Total Environment, 265: 295-307, [DOI]. (Cited on page 24.)

Living Reviews in Landscape Research

http://www. livingreviews.org/lrlr-2010-1 
Sowa, S.P., Annis, G., Morey, M.E. and Diamond, D.D. (2007), "A gap analysis and comprehensive conservation strategy for riverine ecosystems of Missouri", Ecological Monographs, 77(3): 301334, [DOI]. (Cited on page 21.)

Springe, G., Sandin, L., Briede, A. and Skuja, A. (2006), "Biological quality metrics: Their variability and appropriate scale for assessing streams", Hydrobiologia, 566: 153-172, [DOI]. (Cited on page 23.)

Stanford, J.A. and Ward, J.V. (2001), "Revisiting the serial discontinuity concept", Regulated Rivers: Research 83 Management, 17: 303-310, [DOI]. (Cited on page 23.)

Steel, E.A., Feist, B.E., Jensen, D.W., Pess, G.R., Sheer, M.B., Brauner, J.B. and Bilby, R.E. (2004), "Landscape models to understand steelhead (Oncorhynchus mykiss) distribution and help prioritize barrier removals in the Willamette basin, Oregon, USA", Canadian Journal of Fisheries and Aquatic Sciences, 61(6): 999-1011, [DOI]. (Cited on pages 22 and 23.)

Steel, E.A., Fullerton, A.H., Caras, Y., Sheer, M.B., Olson, P., Jensen, D.W., Burke, J., Maher, M. and McElhany, P. (2008), "A spatially explicit decision support system for watershed-scale management of salmon", Ecology and Society, 13(2): 50. URL (accessed 8 March 2010): http://www. ecologyandsociety.org/vol13/iss2/art50/. (Cited on pages 24 and 29.)

Stewart, A.J. (2001), "A simple stream monitoring technique based on measurements of semiconservative properties of water", Environmental Management, 27: 37-46, [DOI]. (Cited on page 19.)

Steyaert, P. and Ollivier, G. (2007), "The European Water Framework Directive: How ecological assumptions frame technical and social change", Ecology and Society, 12(1): 25. URL (accessed 5 March 2010):

http://www. ecologyandsociety.org/vol12/iss1/art25/. (Cited on page 8.)

Stoddard, J.L., Peck, D.V., Paulsen, S.G., Van Sickle, J., Hawkins, C.P., Herlihy, A.T., Hughes, R.M., Kaufmann, P.R., Larsen, D.P., Lomnicky, G., Olsen, A.R., Peterson, S.A., Ringold, P.L. and Whittier, T.R. (2005), "An Ecological Assessment of Western Streams and Rivers", EPA 620/R-05/005, Washington, DC (U.S. Environmental Protection Agency). Online version (accessed 21 October 2009):

http://www.epa.gov/emap/west/html/docs/wstriv.html. (Cited on pages 6, 25, and 27.)

Stoddard, J.L, Herlihy, A.T., Peck, D.V., Hughes, R.M., Whittier, T.R. and E., Tarquinio (2008), "A process for creating multi-metric indices for large-scale aquatic surveys", Journal of the North American Benthological Society, 27(4): 878-891, [DOI]. (Cited on page 25.)

Strayer, D.L., Beighley, R.E., Thompson, L.C., Brooks, S., Nilsson, C., Pinay, G. and Naiman, R.J. (2003), "Effects of land cover on stream ecosystems: Roles of empirical models and scaling issues", Ecosystems, 6(5): 407-423, [DOI]. (Cited on page 27.)

Swanson, F.J., Kratz, T.K., Caine, N. and Woodmansee, R.G. (1988), "Landform effects on ecosystem patterns and processes", BioScience, 38(2): 92-98, [DOI]. (Cited on page 18.)

Talley, T.S. (2007), "Which spatial heterogeneity framework? Consequences for conclusions about patchy population distributions", Ecology, 88(6): 1476-89, [DOI]. (Cited on page 18.)

Taylor, P.D., Farhig, L., Henhein, K. and Merriem, G. (1993), "Connectivity is a vital element of landscape structure", Oikos, 68(3): 571-573, [DOI]. (Cited on page 19.) 
Tejerina-Garro, F.L., de Merona, B., Oberdorff, T. and Hugueny, B. (2006), "A fish-based index of large river quality for French Guiana (South America): method and preliminary results", Aquatic Living Resources, 19: 31-46, [DOI]. (Cited on page 27.)

Tetzlaff, D., Malcolm, I.A. and Soulsby, C. (2007), "Influence of forestry, environmental change and climatic variability on the hydrology, hydrochemistry and residence times of upland catchments", Journal of Hydrology, 346: 93-111, [DOI]. (Cited on page 5.)

Thieme, M., Lehner, B., Abell, R., Hamlton, S.K., Kellndorfer, J., Powell, G. and Riveros, J.C. (2007), "Freshwater conservation planning in data-poor areas: An example from remote Amazonian basin (Madre de Dios River, Peru and Bolivia)", Biological Conservation, 135: 484-501, [DOI]. (Cited on page 21.)

Thompson, D.M. (2006), "Did the pre-1980 use of in-stream structures improve streams? A reanalysis of historical data", Ecological Applications, 16: 784-796, [DOI]. (Cited on page 25.)

Thorp, J.H., Thoms, M.C. and Delong, M.D. (2006), "The riverine ecosystem synthesis: biocomplexity in river networks across space and time", River Research and Applications, 22: 123-147, [DOI]. (Cited on page 29.)

Tockner, K. and Stanford, J.A. (2002), "Riverine flood plains: present state and future trends", Environmental Conservation, 29(3): 308-330, [DOI]. (Cited on page 27.)

Tockner, K., Robinson, C.T. and Uehliner, U., eds. (2009), Rivers of Europe, London (Academic Press). Google Books. (Cited on page 27.)

Toham, A.K. and Teugels, G.G. (1999), "First data on an index of biotic integrity (IBI) based on fish assemblages for the assessment of the impact of deforestation in a tropical west African river system", Hydrobiologia, 397: 29-38. (Cited on page 27.)

Tonn, W.M. (1990), "Climate change and fish communitites: a conceptual framework", Transactions of the American Fisheries Society, 119: 337-352, [DOI]. (Cited on pages 12 and 19.)

Torgersen, C.E., Price, D.M., Li, H.W. and McIntosh, B.A. (1999), "Multiscale thermal refugia and stream habitat associations of Chinook salmon in northeastern Oregon", Ecological Applications, 9(1): 301-319, [DOI]. (Cited on page 16.)

Torgersen, C.E., Faux, R.N., McIntosh, B.A., Poage, N.J. and Norton, D.J. (2001), "Airborne thermal remote sensing for water temperature assessment in rivers and streams", Remote Sensing of Environment, 76(3): 386-398, [DOI]. (Cited on page 16.)

Torgersen, C.E., Baxter, C.V., Li, H.W. and McIntosh, B.A. (2006), "Landscape influences on longitudinal patterns of river fishes: Spatially continuous analysis of fish-habitat relationships", in Hughes, R.M., Wang, L. and Seelbach, P.W., eds., Landscape Influences on Stream Habitats and Biological Assemblages, Proceedings of the Symposium held in Madison, Wisconsin, USA, 25-26 August 2004, AFS Symposium, 48, pp. 473-492, Bethesda, MD (American Fisheries Society). (Cited on page 18.)

Townsend, C.R. (1996), "Concepts in river ecology: Pattern and process in the catchment hierarchy", Archiv für Hydrobiologie Supplement, 113: 3-21. (Cited on page 18.)

Townsend, C.R., Arbuckle, C.J., Crowl, T.A. and Scarsbrook, M.R. (1997), "The relationship between land use and physicochemistry, food resources and macroinvertebrate communities in tributaries of the Taieri River, New Zealand: a hierarchically scaled approach", Freshwater Biology, 37: 177-191, [DOI]. (Cited on page 12.)

Living Reviews in Landscape Research

http://www. livingreviews . org/lrlr-2010-1 
Turner, M.G. (2005), "Landscape ecology in North America: Past, present, and future", Ecology, 86(8): 1967-74, [DOI]. (Cited on page 18.)

Turner, M.G., O’Neill, R.V., Gardner, R.H. and Milne, B.T. (1989), "Effects of changing spatial scale on the analysis of landscape pattern", Landscape Ecology, 3: 153-162, [DOI]. (Cited on page 18.)

Turner, M.G., Arthaud, G.J., Engstrom, R.T., Hejl, S.J., Liu, J., Loeb, S. and McKelvey, K. (1995), "Usefulness of spatially explicit population models in land management", Ecological Applications, 5(1): 12-16, [DOI]. (Cited on page 29.)

USEPA (2009), "National Lakes Assessment: A Collaborative Survey of the Nation's Lakes", EPA841/R-09/001, Washington, DC (U.S. Environmental Protection Agency). URL (accessed 5 March 2010):

http://www.epa.gov/lakessurvey/. (Cited on pages $6,8,25$, and 27.)

Uuemaa, E., Antrop, M., Roosaare, J., Marja, R. and Mander, Ü. (2009), "Landscape Metrics and Indices: An Overview of Their Use in Landscape Research", Living Reviews in Landscape Research,3(1). URL (accessed 9 April 2010):

http://www.livingreviews.org/lrlr-2009-1. (Cited on page 30.)

Van Sickle, J. and Johnson, C.B. (2008), "Parametric distance weighting of landscape influence on streams", Landscape Ecology, 23: 427-438, [DOI]. (Cited on pages 29 and 30.)

Van Sickle, J. and Paulsen, S.G. (2008), "Assessing the attributable risks, relative risks, and regional extents of aquatic stressors", Journal of the North American Benthological Society, 27: 920-931, [DOI]. (Cited on page 27.)

Van Sickle, J., Baker, J., Herlihy, A., Bayley, P., Gregory, S., Haggerty, P., Ashkenas, L. and Li, J. (2004), "Projecting the biological condition of streams under alternative scenarios of human land use", Ecological Applications, 14(2): 368-380, [DOI]. (Cited on pages 18, 23, and 28.)

Vannote, R.L., Minshall, G.W., Cummins, K.W., Sedell, J.R. and Cushing, C.E. (1980), "The river continuum concept", Canadian Journal of Fisheries and Aquatic Sciences, 37(1): 130-137, [DOI]. (Cited on pages 5, 10, 12, and 19.)

Vitousek, P.M., Ehrlich, P.R., Ehrlich, A.H. and Matson, P.A. (1986), "Human appropriation of the products of photosynthesis", BioScience, 36: 368-373, [DOI]. (Cited on page 27.)

Vitousek, P.M., Mooney, H.A., Lubchenco, J. and Melillo, J.M. (1997), "Human domination of Earth's ecosystems", Science, 267: 880-883, [DOI]. (Cited on page 27.)

Walsh, C.J., Roy, A.H., Feminella, J.W., Cottingham, P.D., Groffman, P.M. and Morgan II, R.P. (2005), "The urban stream syndrome: current knowledge and the search for a cure", Journal of the North American Benthological Society, 24(3): 706-723, [DOI]. (Cited on page 21.)

Walter, R.C. and Merritts, D.J. (2008), "Natural streams and the legacy of water-powered mills", Science, 319: 299-304, [DOI]. (Cited on page 28.)

Walters, D.M., Leigh, D.S., Freeman, M.C., Freeman, B.J. and Pringle, C.M. (2003), "Geomorphology and fish assemblages in a Piedmont river basin, U.S.A.", Freshwater Biology, 48(11): 1950-1970, [DOI]. (Cited on page 19.)

Wang, L., Lyons, J., Kanehl, P. and Bannerman, R. (2001), "Impacts of urbanization on stream habitat and fish across multiple spatial scales", Environmental Management, 28: 255-266, [DOI]. (Cited on page 19.) 
Wang, L., Seelbach, P.W. and Hughes, R.M. (2006a), "Introduction to landscape influences on stream habitats and biological assemblages", in Hughes, R.M., Wang, L. and Seelbach, P.W., eds., Landscape Influences on Stream Habitats and Biological Assemblages, Proceedings of the Symposium held in Madison, Wisconsin, USA, 25-26 August 2004, AFS Symposium, 48, pp. 1-23, Bethesda, MD (American Fisheries Society). (Cited on pages 18 and 19.)

Wang, L., Seelbach, P.W. and Lyons, J. (2006b), "Effects of levels of human disturbance on the influence of catchment, riparian, and reach-scale factors on fish assemblages", in Hughes, R.M., Wang, L. and Seelbach, P.W., eds., Landscape Influences on Stream Habitats and Biological Assemblages, Proceedings of the Symposium held in Madison, Wisconsin, USA, 25-26 August 2004, AFS Symposium, 48, pp. 199-219, Bethesda, MD (American Fisheries Society). (Cited on pages 22,24 , and 27 .)

Wang, L.Z., Lyons, J. and Kanehl, P. (2006c), "Habitat and fish responses to multiple agricultural best management practices in a warm water stream", Journal of the American Water Resources Association, 42(4): 1047-1062, [DOI]. (Cited on page 22.)

Waples, R.S., Pess, G.R. and Beechie, T.J. (2008), "Evolutionary history of Pacific salmon in dynamic environments", Evolutionary Applications, 1(2): 189-206, [DOI]. (Cited on page 29.)

Ward, J.V. (1989), "The four-dimensional nature of lotic ecosystems", Journal of the North American Benthological Society, 8: 2-8, [DOI]. (Cited on page 12.)

Ward, J.V. (1998), "Riverine landscapes: Biodiversity patterns, disturbance regimes and aquatic conservation", Biological Conservation, 83(3): 269-278, [DOI]. (Cited on page 12.)

Ward, J.V. and Stanford, J.A. (1995), "Ecological connectivity in alluvial river ecosystems and its disruption by flow regulation", Regulated Rivers: Research 8 Management, 11: 105-119, [DOI]. (Cited on page 23.)

Ward, J.V., Malard, F. and Tockner, K. (2002), "Landscape ecology: A framework for integrating pattern and process in river corridors", Landscape Ecology, 17: 35-45, [DOI]. (Cited on page 18.)

Water Framework Directive (2000), "Directive 2000/60/EC of the European Parliament and of the Council establishing a framework for the Community action in the field of water policy", Brussels (Environment Directorate-General of the European Commission). Online version (accessed 18 November 2009):

http: //eur-lex . europa. eu/LexUriServ/LexUriServ .do?uri=CELEX : 32000L0060 : EN : NOT. (Cited on page 8.)

Weber, C., Peter, A. and Zanini, F. (2007), "Spatio-temporal analysis of fish and their habitat: a case study on a highly degraded Swiss river system prior to extensive rehabilitation", Aquatic Sciences, 69(1): 162-172, [DOI]. (Cited on page 23.)

Wehrly, K.E., Wiley, M.J. and Seelbach, P.W. (2006), "Influence of landscape features on summer water temperatures in lower Michigan streams", in Hughes, R.M., Wang, L. and Seelbach, P.W., eds., Landscape Influences on Stream Habitats and Biological Assemblages, Proceedings of the Symposium held in Madison, Wisconsin, USA, 25-26 August 2004, AFS Symposium, 48, pp. 113-127, Bethesda, MD (American Fisheries Society). (Cited on page 29.)

Whittier, T.R., Stoddard, J.L., Hughes, R.M. and Lomnicky, G.A. (2006), "Associations among catchment- and site-scale disturbance indicators and biological assemblages at least- and mostdisturbed stream and river sites in the western United States", in Hughes, R.M., Wang, L. and Seelbach, P.W., eds., Landscape Influences on Stream Habitats and Biological Assemblages,

Living Reviews in Landscape Research

http://www. livingreviews.org/lrlr-2010-1 
Proceedings of the Symposium held in Madison, Wisconsin, USA, 25-26 August 2004, AFS Symposium, 48, pp. 641-664, Bethesda, MD (American Fisheries Society). (Cited on page 28.)

Wichert, G.A. and Rapport, D.J. (1998), "Fish community structure as a measure of degradation and rehabilitation of riparian systems in an agricultural drainage basin", Environmental Management, 22(3): 425-443, [DOI]. (Cited on page 22.)

Wiens, J.A. (1989), "Spatial scaling in ecology", Functional Ecology, 3(4): 385-397, [DOI]. (Cited on page 18.)

Wiens, J.A. (2002), "Riverine landscapes: Taking landscape ecology into the water", Freshwater Biology, 47(4): 501-515, [DOI]. (Cited on pages 12 and 18.)

Wiley, M.J., Kohler, S.L. and Seelbach, P.W. (1997), "Reconciling landscape and local views of aquatic communities: Lessons from Michigan trout streams", Freshwater Biology, 37: 133-148, [DOI]. (Cited on page 12.)

Wright, A., Marcus, W.A. and Aspinall, R. (2000), "Evaluation of multispectral, fine scale digital imagery as a tool for mapping stream morphology", Geomorphology, 33(1-2): 107-120, [DOI]. (Cited on page 16.)

Wu, J. (2004), "Effects of changing scale on landscape pattern analysis: scaling relations", Landscape Ecology, 19: 125-138, [DOI]. (Cited on page 18.)

Wu, J. and Hobbs, R. (2002), "Key issues and research priorities in landscape ecology: An idiosyncratic synthesis", Landscape Ecology, 17(4): 355-365, [DOI]. (Cited on page 21.)

Wu, J., Shen, W., Sun, W. and Tueller, P.T. (2002), "Empirical patterns of the effects of changing scale on landscape metrics", Landscape Ecology, 17: 761-782, [DOI]. (Cited on page 18.)

Wu, J., Huang, J., Han, X., Xie, Z. and Gao, X. (2003), "Three-Gorges Dam - Experiment in habitat fragmentation?", Science, 300: 1239-1240, [DOI]. (Cited on page 20.)

Wulder, M.A., Hall, R.J., Coops, N.C. and Franklin, S.E. (2004), "High spatial resolution remotely sensed data for ecosystem characterization", BioScience, 54(6): 511-521, [DOI]. (Cited on page 10.)

Xie, P. (2003), "Three-Gorges Dam: Risk to ancient fish", Science, 302: 1149, [DOI]. (Cited on page 20.)

Yates, A.G. and Bailey, R.C. (2006), "The stream and its altered valley: Integrating landscape ecology into environmental assessments of agro-ecosystems", Environmental Monitoring and Assessment, 114(1-3): 257-271, [DOI]. (Cited on pages 25 and 28.)

Yoder, C.O., Rankin, E.T., Smith, M.A., Alsdorf, B.C., Altfater, D.J., Boucher, C.E., Miltner, R.J., Mishne, D.E., Sanders, R.E. and Thoma, R.F. (2005), "Changes in fish assemblage status in Ohio's nonwadeable rivers and streams over two decades", in Rinne, J.N., Hughes, R.M. and Calamusso, B., eds., Historical Changes in Large Fiver Fish Assemblages of the Americas, Proceedings of the Symposium held in Phoenix, Arizona, USA, 21 August 2001, AFS Symposium, 45, pp. 399-342, Bethesda, MD (American Fisheries Society). (Cited on page 22.)

Zalewski, M.G., Janauer, G.A. and Jolánkaj, G. (1997), "Ecohydrology: A New Paradigm for the Sustainable Use of Aquatic Resources. Conceptual Background, Working Hypothesis, Rationale and Scientific Guidelines for the Implementation of the IHP-V Projects 2.3/2.4", Technical Documents in Hydrology, 7, Paris (UNESCO). Online version (accessed 5 March 2010): http://unesdoc.unesco.org/images/0010/001062/106296e.pdf. (Cited on page 29.) 
Zorn, T.G. and Wiley, M.J. (2006), "Influence of landscape characteristics on local habitat and fish biomass in streams of Michigan's Lower Peninsula", in Hughes, R.M., Wang, L. and Seelbach, P.W., eds., Landscape Influences on Stream Habitats and Biological Assemblages, Proceedings of the Symposium held in Madison, Wisconsin, USA, 25-26 August 2004, AFS Symposium, 48, pp. 375-393, Bethesda, MD (American Fisheries Society). (Cited on page 29.)

Zweimüller, I., Zessner, M. and Hein, T. (2008), "Effects of climate change on nitrate loads in a large river: the Austrian Danube as example", Hydrological Processes, 22(7): 1022-1036, [DOI]. (Cited on page 5.) 